\title{
ALTERAÇÕES FISIOLÓGICAS E DE COMPOSIÇÃO EM Saccharomyces cerevisiae SOB CONDIÇÕES NÃO PROLIFERANTES
}

\section{ANDRÉ EduARdo de SoUZa BELLUCo}

Dissertação apresentada à Escola Superior de Agricultura "Luiz de Queiroz", Universidade de São Paulo, para obtenção do título de Mestre em Ciências, Área de Concentração: Ciência e Tecnologia de Alimentos.

\author{
PIRACICAB A \\ Estado de São Paulo - Brasil \\ Julho - 2001
}




\title{
ALTERAÇÕES FISIOLÓGICAS E DE COMPOSIÇÃO EM Saccharomyces cerevisiae SOB CONDIÇÕES NÃO PROLIFERANTES
}

\section{André EduARdo de Souza Belluco}

\author{
Engenheiro Agrônomo
}

Orientador: Prof. Dr. JORGE HORII

\begin{abstract}
Dissertação apresentada à Escola Superior de Agricultura "Luiz de Queiroz", Universidade de São Paulo, para obtenção do título de Mestre em Ciências, Área de Concentração: Ciência e Tecnologia de Alimentos.
\end{abstract}

PIR A C I C A B A

Estado de São Paulo - Brasil

Julho -2001 


\title{
Dados Internacionais de Catalogação na Publicação (CIP) DIVISÃo DE BIBLIOTECA E DOCUMENTAÇÃ̃o - Campus “Luiz de Queiroz”/USP
}

\author{
Belluco, André Eduardo de Souza \\ Alterações fisiológicas e de composição em Saccharomyces cerevisiae sob \\ condições não proliferantes / André Eduardo de Souza Belluco. - - Piracicaba, \\ 2001. \\ $84 \mathrm{p}$. \\ Dissertação (mestrado) - - Escola Superior de Agricultura Luiz de Queiroz, \\ 2001. \\ Bibliografia. \\ 1. Autólise 2. Levedura 3. Trealose 4. Viabilidade I. Título
}

CDD 589.23

\section{'Permitida a cópia total ou parcial deste documento, desde que citada a fonte - $O$ autor"}


Aos meus pais,

Celso Belluco e

Neide Gumbis de Souza Belluco,

Dedico

Às minhas irmãs, Claudia e Cristina, querida Elaine e aos meus pequenos sobrinhos, Gabriel, Kim e Kimberly, Ofereço 


\section{AGRADECIMENTOS}

À Deus, pela existência e força para percorrer a trilha da vida.

À Escola Superior de Agricultura "Luiz de Queiroz", em especial ao Departamento de Agroindústria, Alimentos e Nutrição, pela formação profissional e apoio de seus funcionários e professores.

Ao Conselho Nacional de Desenvolvimento Científico e Tecnológico (CNPq), pela bolsa de estudos oferecida durante o curso de Mestrado.

Ao Prof. Dr. Jorge Horii, pela amizade, orientação durante a realização do trabalho e por proporcionar amplo conhecimento de vida.

Ao Prof. Dr. Luiz Eduardo Gutierrez, pela amizade, e auxílios em Bioquímica.

À Profa. Dra. Marília Oetterer, pela amizade, apoio e ensinamentos durante o curso.

Ao Prof Dr. André Ricardo Alcarde, pela amizade e incentivo.

À amiga Regina Helena Gonçalves, pelo enorme auxílio nas análises laboratoriais.

À Silene Paulillo, pela amizade e incentivo. 
À Profa. Dra. Gláucia Maria Bovi Ambrosano, pela colaboração nas análises estatísticas.

À Rosemeire Dichaune e Cel-Lep escola de idiomas pelo auxílio nas correções do SUMMARY.

Às Bibliotecárias Beatriz Helena Giongo e Midian Gustinelli, pela amizade e auxílio na organização das referências bibliográficas.

À todos os meus amigos de pós-graduação, Anny, Antonio, Ariovaldo, Carlos, Evelise, Juliana, Mariana, Patrícia, Solange e todos aqueles que contribuíram de alguma forma para a realização do trabalho.

Aos meus familiares, pelo apoio e compreensão, com destaque para Alfredo, Antonia, Sergio, Waldir, Euclydes, Edviges, Kathia, Lygia, Marcio, Maria, Joaquim e Marco.

À empresa Mauri do Brasil, pelo fornecimento das leveduras Saccharomyces cerevisiae Y904. 


\section{SUMÁRIO}

Página

LISTA DE FIGURAS.......................................................................... viii

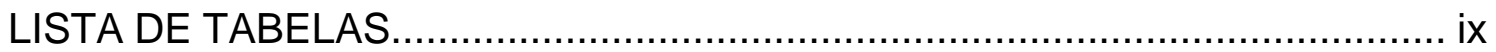

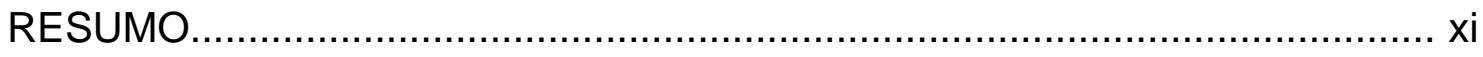

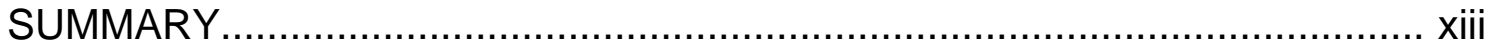

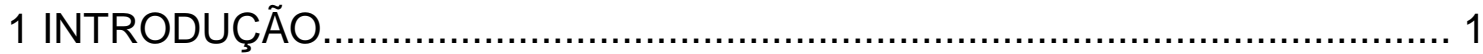

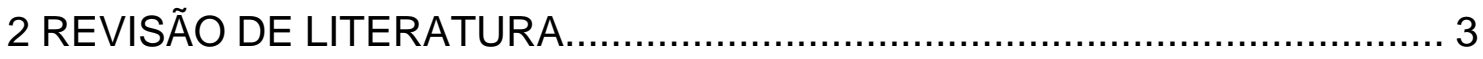

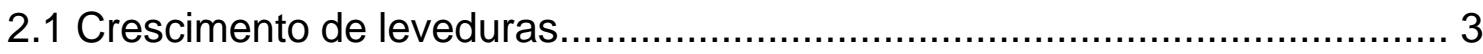

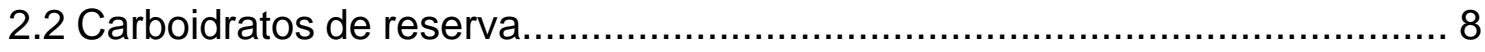

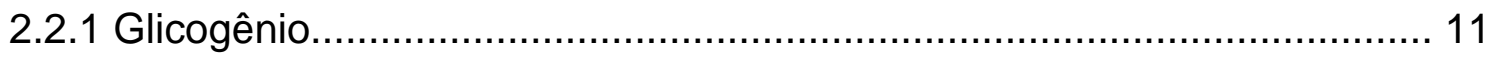

2.2.1.1 Acúmulo de glicogênio em leveduras.............................................. 11

2.2.1.2 Mobilização de glicogênio em leveduras............................................. 12

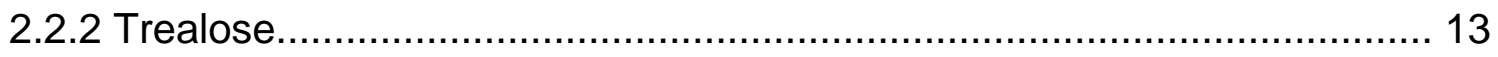

2.2.2.1 Acúmulo de trealose em leveduras................................................. 14

2.2.2.2 Mobilização de trealose em leveduras............................................... 16

2.3 Viabilidade celular em leveduras........................................................ 17

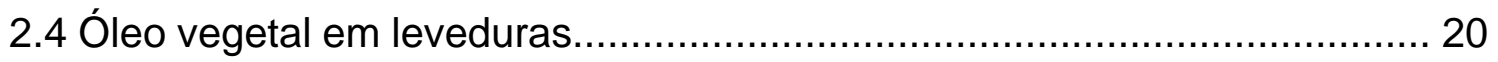

2.5 Condições não favoráveis à proliferação.................................................. 23

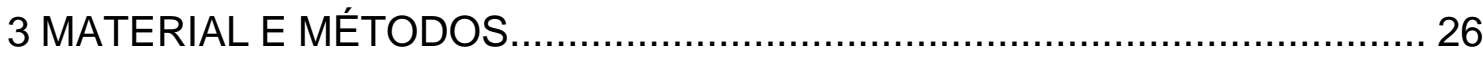

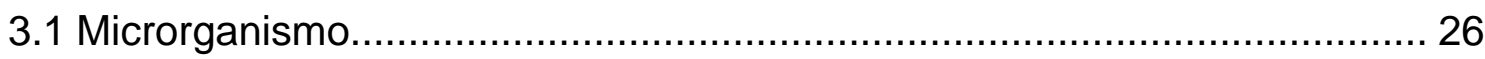

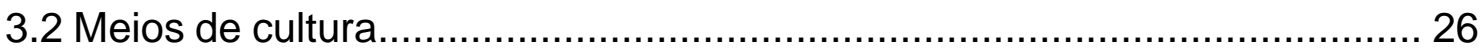

3.2.1 Meios de manutenção e de reativação das células desidratadas............. 26 


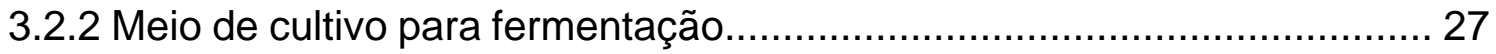

3.3 Verificação da pureza da levedura comercial desidratada......................... 28

3.3.1 Reativação da cultura desidratada para isolamento............................... 28

3.3.2 Isolamento e purificação das culturas de leveduras................................ 28

3.4 Fermentação e obtenção das leveduras para análise ................................ 29

3.4.1 Monitoramento das alterações fisiológicas na suspensão celular............ 30

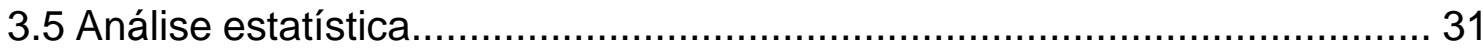

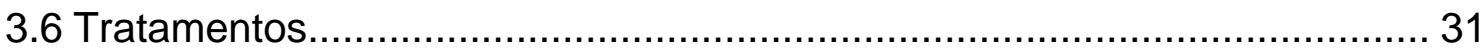

3.7 Análises físico-químicas e microbiológicas............................................ 31

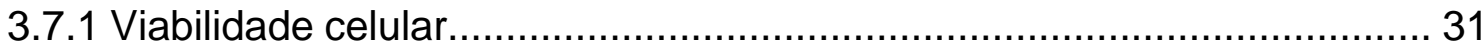

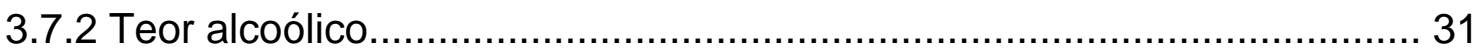

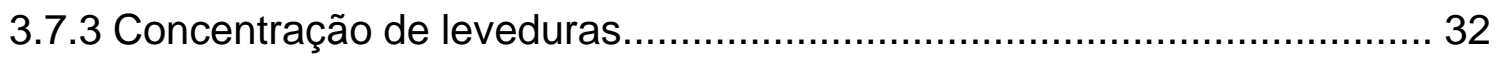

3.7.4 Nitrogênio total, na matéria seca...................................................... 32

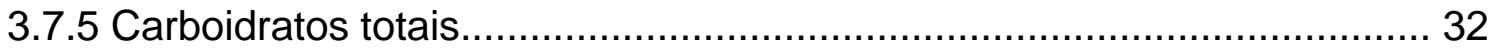

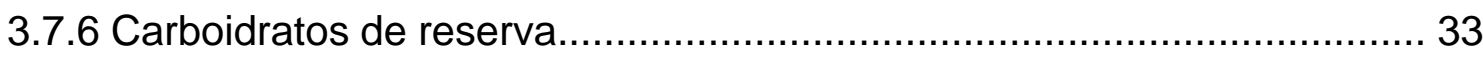

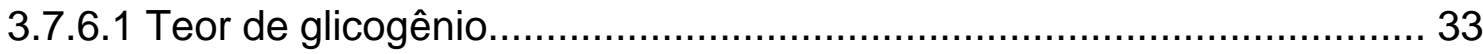

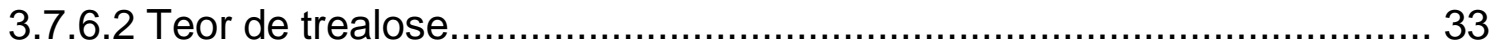

3.7.7 Levedura referência......................................................................... 33

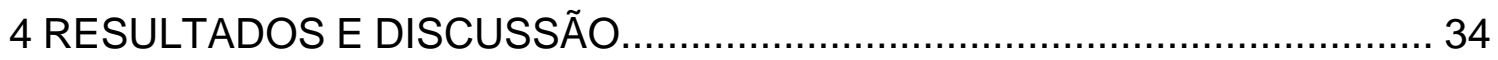

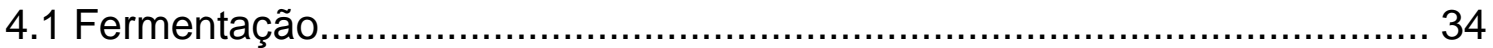

4.2 Monitoramento das alterações fisiológicas na suspensão celular............... 38

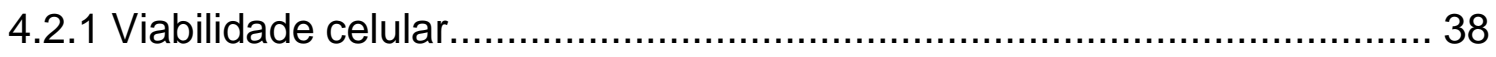

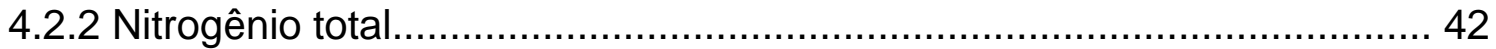

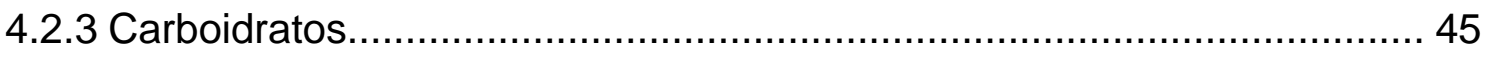

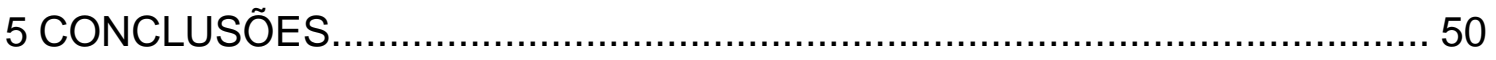

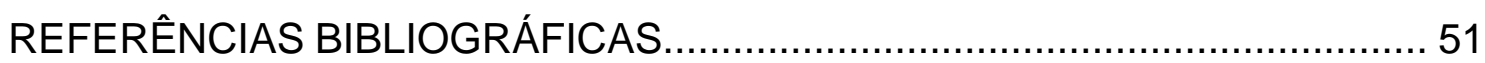

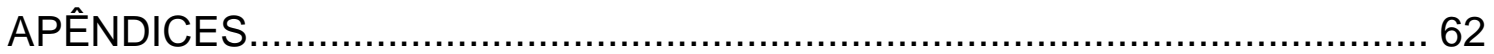




\section{LISTA DE FIGURAS}

Página

1 Metodologia para isolamento e purificação de leveduras............................... 29

2 Acompanhamento da fermentação pela diferença média de massa em

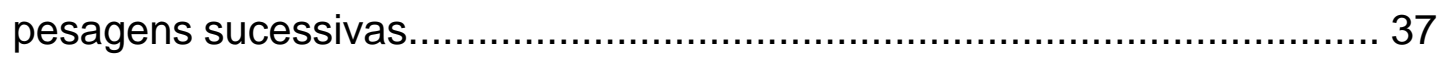

3 Perfil da viabilidade celular de Saccharomyces cerevisiae Y904 em condições não proliferantes, sob agitação............................................... 40

4 Concentração celular de Saccharomyces cerevisiae em condições não proliferantes ao longo do período de 8 dias.............................................. 42

5 Nitrogênio total na suspensão celular e no meio líquido............................... 43

6 Nitrogênio na massa seca de leveduras...................................................... 44

7 Carboidratos totais obtidos na suspensão celular de leveduras, após coleta

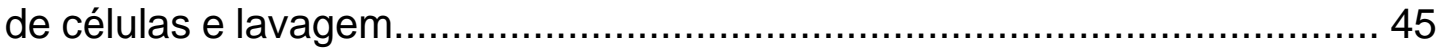

8 Trealose em leveduras mantidas em condições não proliferantes ao longo de $192 \mathrm{~h}$. Teores percentuais em relação à matéria seca............................ 47

9 Teores de trealose expressos em porcentagem dos carboidratos totais no decorrer de $192 \mathrm{~h}$, em condições não proliferantes de S. cerevisiae, em solução fisiológica de $\mathrm{KCl}$ 0,154M

10 Glicogênio em leveduras. Teores percentuais em relação a matéria seca de S. cerevisiae mantida em condições não proliferantes ao longo de $192 \mathrm{~h}$. 


\section{LISTA DE TABELAS}

Página

1 Composição molecular de levedura comercial e melaço................................. 4

2 Composição química aproximada da levedura seca..................................... 5

3 Teores de $\mathrm{N}$ na matéria seca do fermento e na água ácida da suspensão em função do tempo (h) e dos tratamentos..................................................... 7

4 Caracterização e quantificação dos carboidratos presentes em leveduras..... 9

5 Composição de carboidratos de algumas linhagens de Saccharomyces

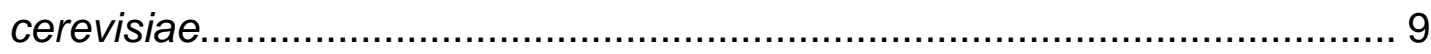

6 Resultados de concentração celular (g/L), em ensaios com mosto de $310 \mathrm{~g}$ ART/L, com 3 repetições.

7 Viabilidade celular (\%), nos ensaios com mosto de $310 \mathrm{~g}$ ART/L, com 3

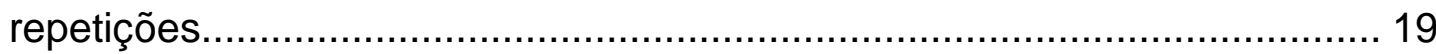

8 Meio de cultura YEPD ágar "Yeast extract peptone dextrose agar" para manutenção da linhagem e plaqueamento.............................................. 26

9 Meio de cultivo YEPD líquido "Yeast extract peptone dextrose" para reativação da linhagem comercial.

10 Meio de cultivo YEPS "Yeast extract peptone sucrose" para fermentação. 27

11 Viabilidade celular em leveduras para realização da fase de fermentação.. 35

12 Contagem das unidades formadoras de colônias de leveduras após fase de reativação. 36

13 Teor alcoólico das amostras fermentadas em presença ou ausência de óleo de soja 
14 Viabilidade celular, nitrogênio total, carboidratos totais, trealose e glicogênio em levedura reidratada em água.............................................. 39 


\title{
ALTERAÇÕES FISIOLÓGICAS E DE COMPOSIÇÃO EM Saccharomyces cerevisiae SOB CONDIÇÕES NÃO PROLIFERANTES
}

\author{
Autor: ANDRÉ EDUARDO DE SOUZA BELLUCO \\ Orientador: Prof. Dr. JORGE HORII
}

\section{RESUMO}

As leveduras são de relevante importância dentro da agroindústria sucroalcooleira devido sua participação no processo fermentativo de produção de álcool. Deste modo, faz-se necessário o conhecimento deste agente fermentativo com destaque para Saccharomyces cerevisiae, principal gênero.

O objetivo deste trabalho foi estudar a linhagem de levedura $S$. cerevisiae Y904, exposta a condições não proliferantes, após fermentação em meio que sofreu adição de óleo vegetal e sua possível correlação com manutenção da viabilidade celular. Foram realizadas análises para contagem de unidades formadoras de colônias, viabilidade celular, concentração celular, nitrogênio total na levedura e no meio, carboidratos totais, trealose e glicogênio.

As leveduras submetidas a condições não proliferantes apresentaram menores teores de carboidratos totais, com destaque para trealose e glicogênio, em relação às leveduras comerciais.

Saccharomyces cerevisiae sofreu queda de viabilidade acentuada após 24 h em solução fisiológica, em condições não proliferantes, sob agitação 
de $90 \mathrm{rpm}$ e temperatura de $30 \pm 1^{\circ} \mathrm{C}$, seguida de uma acentuada autólise a partir de $120 \mathrm{~h}$ ( $5^{\circ} \mathrm{dia}$ ), provavelmente, devido ao teor de carboidratos de reserva da célula que se encontravam em valores extremamente baixos, da ordem de $0,15 \mathrm{mg}$ de trealose em $100 \mathrm{mg}$ da matéria seca e $4 \mathrm{mg}$ de glicogênio em $100 \mathrm{mg}$ da matéria seca. A partir desse ponto entraram em total desorganização celular. 


\title{
PHYSIOLOGICAL AND COMPOSITION CHANGES IN Saccharomyces cerevisiae UNDER NON-PROLIFERATING CONDITIONS
}

\author{
Author: ANDRÉ EDUARDO DE SOUZA BELLUCO \\ Adviser: Prof. Dr. JORGE HORII
}

\section{SUMMARY}

Yeast is highly important in sugar and alcohol agroindustry due to its role in the fermentative process of alcohol production. Thus, it is necessary to know this microorganism, most specially the Saccharomyces cerevisiae, the main species.

The objective of this work was to study the strain Y904 of the yeast Saccharomyces cerevisiae under non-proliferating conditions after fermentation in a medium in which it was added vegetable oil and verify its possible correlation with the maintenance of the cellular viability.

Analyses were performed in order to determine colony forming units, cellular viability, cellular concentration, total nitrogen in yeast and in medium, total carbohydrates and trehalose and glycogen contents.

The yeast submitted to non-proliferating conditions presented a lower content of total carbohydrates, specially trehalose and glycogen, when compared to commercial yeasts. 
The viability of the yeast Saccharomyces cerevisiae Y904 markedly decreased after 24 hours in physiological solution under non-proliferating conditions in a shaker for $90 \mathrm{rpm}$ at $30 \pm 1^{\circ} \mathrm{C}$. It was observed an accentuated autolysis from the $120^{\text {th }}$ hour ( $5^{\text {th }}$ day) on. This was probably because of the very low content of the carbohydrates of reserve in the cells, $0.15 \mathrm{mg}$ of trehalose and $4.0 \mathrm{mg}$ of glycogen in $100 \mathrm{mg}$ of dry weight. From this point the cells began a total cellular disorganization. 


\section{INTRODUÇÃO}

A fermentação é uma transformação bioquímica provocada num substrato por fermento vivo ou por um princípio extraído deste fermento. A importância deste processo está diretamente relacionada com diversos setores da agroindústria, com destaque para a alcooleira. O setor alcooleiro, no Brasil, utiliza-se, de leveduras, do gênero Saccharomyces, predominantemente a espécie Saccharomyces cerevisiae e suas diversas linhagens de grande adaptação às condições indústriais.

Devido ao considerável gerador econômico que o setor representa, a produtora de álcool enquadra-se entre as principais, que compõem a agroindústria.

A produção de álcool etílico ultrapassa a 12 bilhões de litros (Carvalho, 2000), e levando-se em consideração que toda a produção de álcool no país é derivada de processo fermentativo, tem se uma grande preocupação no conhecimento do agente responsável pela fermentação. Assim sendo, é de relevante interesse conhecer, o comportamento do microrganismo no tocante a velocidade específica de crescimento, da formação de produto, e toda sua relação com substrato mas, também conhecer a resistência a condições estressantes e não proliferantes como por ocasião de paradas na indústria.

Neste trabalho procurou-se monitorar a Saccharomyces cerevisiae quando exposta a condição não proliferante, isenta de reações adversas, após uma fermentação alcoólica, mantendo-se entretanto o sistema agitado, com maior gasto de energia de manutenção. Foram avaliados os efeitos nas substâncias nitrogenadas, carboidratos de reservas, concentração celular e 
viabilidade celular das leveduras, entre outros fatores, que pudessem interferir, significantemente, dentro deste contexto na ação das leveduras.

\section{Objetivos}

O escopo desta pesquisa foi estudar a:

- influência do teor de carboidratos de reserva sobre o tempo de sobrevivência das células sob condições não proliferantes;

- possibilidade de lipídeos, de óleo de soja comercial adicionado ao substrato da fermentação, exercer alguma influência sobre a sobrevida destas leveduras. 


\section{REVISÃO DE LITERATURA}

\subsection{Crescimento de leveduras}

Segundo Ribeiro et al. (1987), as células de leveduras apresentam necessidades nutricionais durante o processo de fermentação alcoólica, os quais influenciam diretamente na multiplicação e no crescimento celular e também na eficiência da transformação de açúcar em álcool.

O nitrogênio devido a sua importância para as leveduras, é considerado um elemento essencial para a multiplicação e crescimento das leveduras. Este nutriente entra como constituinte de várias substâncias orgânicas encontradas nas leveduras, como os aminoácidos, proteínas, enzimas, piridinas, purinas, pigmentos respiratórios (citocromos), lecitina, vitaminas e cefalina (White, 1954).

Ainda, segundo Harrison (1971), o nitrogênio é um dos principais elementos presentes em leveduras além do carbono, hidrogênio e oxigênio, os quais, normalmente, representam cerca de $94 \%$ da matéria seca, como pode ser observado na Tabela 1. Desta maneira, estes elementos formam as substâncias como os carboidratos glicogênio, celulose e mananas e as substâncias nitrogenadas como as proteínas, ácidos nucléicos e bases orgânicas piridinas e purinas. Do total de nitrogênio presente na levedura, 70\% está, provavelmente, na forma de proteína, enquanto uma menor parte, cerca de 8 a $10 \%$ aparece como purinas e $4 \%$ como piridinas, sendo que o restante do nitrogênio, deve estar presente na forma de componentes solúveis, como aminoácidos e nucleotídeos (White, 1954). 
Tabela 1. Composição molecular de levedura comercial e melaço.

\begin{tabular}{|c|c|c|}
\hline Constituinte & $\begin{array}{c}\text { Levedura } \\
(\mathrm{g} / 100 \mathrm{~g} \text { de matéria seca) }\end{array}$ & $\begin{array}{c}\text { Melaço } \\
(\mathrm{g} / 100 \mathrm{~g} \text { de matéria seca) }\end{array}$ \\
\hline Carbono (C) & $45,00-47,00$ & $39,00-41,00$ \\
\hline Hidrogênio (H) & $6,00-6,50$ & $6,30-6,80$ \\
\hline Oxigênio (O) & $31,00-32,00$ & $47,00-50,00$ \\
\hline Nitrogênio (N) & $7,50-9,00$ & $0,10-2,80$ \\
\hline Potássio (K) & $0,90-3,50$ & $0,80-5,20$ \\
\hline Fósforo (P) & $1,10-2,00$ & $0,01-0,90$ \\
\hline Enxofre (S) & $0,30-0,50$ & $0,15-0,20$ \\
\hline Magnésio (Mg) & $0,15-0,50$ & $0,007-0,75$ \\
\hline Cálcio (Ca) & $0,04-0,90$ & $0,018-1,20$ \\
\hline Sódio (Na) & $0,02-0,20$ & $0,82-1,40$ \\
\hline Zinco (Zn) & $0,004-0,13$ & $0,0006-0,013$ \\
\hline Ferro (Fe) & $0,003-0,10$ & $0,01-0,021$ \\
\hline Cobre (Cu) & $0,002-0,012$ & $0,0001-0,006$ \\
\hline Manganês (Mn) & $0,0004-0,0035$ & $0,001-0,004$ \\
\hline Cobalto (Co) & 0,0005 & $0,00004-0,0001$ \\
\hline Molibdênio (Mo) & $0,000005-0,000009$ & $0,000009-0,000026$ \\
\hline Cloro (Cl) & $0,004-0,10$ & 1,30 \\
\hline lodo (I) & $0,00005-0,0004$ & - \\
\hline Chumbo (Pb) & $0,0001-0,0007$ & 0,0006 \\
\hline Arsênio (As) & 0,00001 & - \\
\hline Silício (Si) & - & 0,028 \\
\hline Estrôncio (Sr) & - & 0,005 \\
\hline Boro (B) & - & $0,0002-0,0004$ \\
\hline
\end{tabular}

Fonte: Harrison (1971)

A composição das leveduras, varia em função de diversos fatores, como o substrato no qual é cultivada, a espécie de levedura, o método de 
fermentação, o modo e as condições de secagem e a idade das células, segundo já citava Desmonts (1968). Além destes fatores, Ghiraldini \& Rossell (1997) citam que no processo de obtenção de levedura de recuperação, as lavagens sucessivas com água, com objetivo de eliminar as impurezas do leite de levedo ou do resíduo do fundo de dornas, podem ocasionar mudanças no que se refere a composição da levedura.

$\mathrm{Na}$ Tabela 2, é mostrada a composição química, aproximada, da levedura seca, de recuperação. A composição de proteína bruta está em torno de $30 \%$ (Lahr Filho et al., 1996).

Segundo Caballero Córdoba et al. (1997), os teores da composição centesimal da biomassa de levedura de cervejaria Saccharomyces $s p$., apresenta elevados teores de proteínas (48,51\%), além de cinzas $(8,33 \%)$, ácido ribonucléico $(7,52 \%)$ e fibra solúvel $(9,59 \%)$, enquanto os teores de lipídeos totais são baixos (3,44 \%) e os de carboidratos totais representam um terço da biomassa $(32,86 \%)$.

Tabela 2. Composição química aproximada da levedura seca.

\begin{tabular}{ccccc}
\hline \multirow{2}{*}{ Discriminação } & Miyada & Fialho et al. & Lima & Moreira \\
& $(1978)$ & $(1983)$ & $(1983)$ & $(1984)$ \\
\hline Matéria seca (\%) & 90,70 & 93,90 & 92,34 & 96,40 \\
Proteína bruta (\%) & 30,77 & 30,62 & 29,17 & 30,23 \\
Extrato etéreo (\%) & 1,10 & 1,60 & 1,22 & 0,89 \\
Fibra bruta (\%) & 0,13 & 2,35 & 0,79 & 0,72 \\
Materia mineral (\%) & 9,81 & 9,82 & 11,81 & 14,43 \\
Cálcio (\%) & 1,48 & 1,19 & 1,23 & 1,52 \\
Fósforo (\%) & 0,75 & 0,67 & 0,59 & 0,68
\end{tabular}

Fonte: Lahr Filho et al. (1996) 
Consta ainda que a composição de aminoácidos das leveduras é bem balanceada, destacando-se os teores elevados de lisina, metionina e treonina (Ghiraldini \& Rossell, 1997).

Morris citado por Ribeiro et al. (1987), destacou a importância da adição de nitrogênio extracelular para que possa ocorrer uma contínua produção de novas células e a levedura possa obter este elemento através de aminoácidos, saís de amônia, amidas e nitratos. A forma como este nutriente se encontra disponível no meio é de grande importância para seu aproveitamento, sendo a mais favorável a amoniacal; na sua ausência são utilizadas outras fontes, e como conseqüência há um aumento de produção de compostos secundários, como os álcoois isoamílico, amílico e propílico (Ribeiro et al., 1987 e Vasconcelos, 1987).

A levedura em suspensão em água ácida sofre mudanças nos componentes nitrogenados podendo ocorrer eventuais excreções deste elemento para o meio, como mostraram Amorim \& Gomes (1988), apresentada na Tabela 3. Ainda, Amorim \& Gomes (1987) observaram a ocorrência de perda de potássio na levedura, sendo que o nitrogênio e as proteínas não sofreram alterações ou apenas pequenas elevações no decorrer do tratamento; isto se deve a hipótese de que há uma perda de material não nitrogenado em maior proporção do que o nitrogenado.

Saccharomyces cerevisiae PE-2 e VR-1, no período de 6 e 8 h de fermentação de acordo com as linhagens, apresentaram baixos teores de nitrogênio no vinho, mas após este tempo com a ocorrência de autólise celular, Ferreira (1998) observou aumento acentuado de nitrogênio no vinho e além de queda da viabilidade celular proporcional ao fenômeno em pauta. 
Tabela 3. Teores de $\mathrm{N}$ na matéria seca do fermento e na água ácida da suspensão em função do tempo (h) e dos tratamentos.

\begin{tabular}{|c|c|c|c|c|c|c|c|c|c|}
\hline \multirow[b]{2}{*}{ Temperatura } & \multirow[b]{2}{*}{$\mathrm{pH}$} & \multirow[b]{2}{*}{ \%células } & \multicolumn{4}{|c|}{$\begin{array}{l}\text { Células de fermento } \\
\qquad N(\%)\end{array}$} & \multicolumn{3}{|c|}{$\begin{array}{c}\text { Água ácida da } \\
\text { suspensão (N ppm) }\end{array}$} \\
\hline & & & $0 \mathrm{~h}$ & $1,5 \mathrm{~h}$ & $3 \mathrm{~h}$ & $6 \mathrm{~h}$ & $1,5 \mathrm{~h}$ & $3 \mathrm{~h}$ & $6 \mathrm{~h}$ \\
\hline & 2,00 & 30,00 & 7,21 & 7,45 & 7,56 & 7,28 & 14,00 & 21,00 & 25,00 \\
\hline & & 40,00 & 6,58 & 6,86 & 7,21 & 6,65 & 41,30 & 46,20 & 48,20 \\
\hline \multirow[t]{6}{*}{ Ambiente } & 2,50 & 30,00 & 6,96 & 6,82 & 6,82 & 6,83 & 26,60 & 32,90 & 34,30 \\
\hline & & 40,00 & 6,75 & 6,65 & 6,58 & 6,72 & 35,70 & 38,50 & 38,50 \\
\hline & 3,00 & 30,00 & 6,51 & 6,51 & 6,77 & 7,00 & 13,44 & 14,00 & 13,72 \\
\hline & & 40,00 & 7,07 & 6,58 & 6,23 & 6,37 & 24,64 & 25,40 & 25,40 \\
\hline & 2,00 & 30,00 & 6,93 & 6,72 & 7,00 & 7,00 & 25,00 & 26,00 & 31,00 \\
\hline & & 40,00 & & & & & 17,50 & 21,70 & 25,20 \\
\hline \multirow[t]{6}{*}{$30^{\circ} \mathrm{C}$} & 2,50 & 30,00 & & & & & 24,60 & 24,48 & 30,00 \\
\hline & & 40,00 & 6,55 & 5,88 & 5,95 & 6,44 & 25,00 & 26,00 & 29,00 \\
\hline & 3,00 & 30,00 & 5,89 & 6,93 & 6,60 & 6,44 & 10,00 & 11,34 & 11,06 \\
\hline & & 40,00 & 6,78 & 6,65 & 6,65 & 6,65 & 30,00 & 33,00 & 37,00 \\
\hline & 2,00 & 30,00 & & & & & 16,38 & 17,64 & 23,00 \\
\hline & & 40,00 & 6,37 & 6,09 & 6,23 & 6,16 & 28,28 & 33,60 & 40,74 \\
\hline \multirow[t]{4}{*}{$40^{\circ}$} & 2,50 & 30,00 & 6,16 & 6,37 & 6,65 & 6,37 & & & \\
\hline & & 40,00 & 6,37 & 6,44 & 6,58 & 6,51 & 21,28 & 26,60 & 27,02 \\
\hline & 3,00 & 30,00 & 6,79 & 6,65 & 6,80 & 7,00 & 10,50 & 13,00 & 15,54 \\
\hline & & 40,00 & 6,37 & 6,16 & 6,44 & 6,72 & 41,44 & 54,04 & 73,36 \\
\hline
\end{tabular}

Fonte: Amorim \& Gomes (1988) 
As proteínas presentes nas leveduras, além de exercerem importantes funções metabólicas, apresentam grande interesse comercial. Nogueira \& Oliva Neto (2000) apontaram que a levedura resultante da fermentação alcoólica industrial está sendo recuperada na forma de subproduto para ser comercializada como alimento protéico, para ração animal, no mercado interno e externo; é também destacado que geralmente o conteúdo protéico dos microrganismos é mais elevado em relação à maioria das outras fontes. Caballero Córdoba et. al. (1997) destacaram que a produção de isolados e concentrados protéicos, a partir de microrganismos, como as leveduras, bactérias e algas, tem sido muito considerado nestas últimas décadas, sendo que Halàsz et al. (1988) afirmaram, que estes são boas fontes protéicas não convencionais, devido ao teor elevado de proteínas que apresentam (45-65\%).

Ghiraldini \& Rossell (1997), relataram um aumento no teor de proteínas da levedura, através do consumo dos carboidratos de reserva, os quais resultaram em álcool, ocorrendo consequentemente uma perda de matéria seca no processo.

\subsection{Carboidratos de reserva}

O açúcar que se encontra no mosto é utilizado pela levedura para a produção de etanol, gás carbônico, massa celular, glicerol, ácidos succínico e acético, álcoois superiores, ésteres, trealose, entre outros produtos.

Segundo Peppler (1970) as leveduras utilizadas em alimentação têm, em sua composição, $22 \%$ a $34 \%$ de carboidratos, sendo que este varia com a composição do meio de crescimento e o nível de aerobiose mantido. Chen (1959 a $\underline{\text { ab) }}$ ) verificou que $25 \%$ do peso seco das células era carboidrato e isolou quatro frações que calculava ser aproximadamente $94 \%$ do total (Tabela 4). Manners (1971), mostrou diversos teores de carboidratos em leveduras de panificação e de cervejaria e um baixo conteúdo de trealose quando a mesma foi submetida a crescimento em condições aeróbias (Tabela 5). White (1954), 
relatou uma composição de glicogênio de 1 até $30 \%$ de matéria seca de levedura.

Tabela 4. Caracterização e quantificação dos carboidratos presentes em leveduras.

\begin{tabular}{cc}
\hline Carboidratos & $25 \%$ da matéria seca da levedura \\
\hline Trealose & Carboidratos $(\%)$ \\
Glucanos & 33 \\
Mananas & 27 \\
Glicogênio & 21 \\
\hline
\end{tabular}

Fonte: Chen (1959aeㅁ)

Tabela 5. Composição de carboidratos de algumas linhagens de Saccharomyces cerevisiae.

\begin{tabular}{cccccc}
\hline Carboidrato & \multicolumn{5}{c}{ Conteúdo de carboidratos } \\
& \multicolumn{5}{c}{ Cervejaria } \\
\hline & Panificação & \multicolumn{4}{c}{} \\
Trealose & 57 & 4236 & $4236^{*}$ & 7000 & 7001 \\
Glicogênio & 62 & 8 & 1 & 5 & 6 \\
Manana & 16 & 76 & 38 & 71 & 52 \\
$\beta$ - Glucana & 16 & 9 & 36 & 12 & 24 \\
& & 7 & 26 & 12 & 19
\end{tabular}

Fonte: Manners (1971)

* Levedura crescida aerobicamente. Todas outras leveduras foram crescidas anaerobicamente, a $25^{\circ} \mathrm{C}$, e por tempo de $48 \mathrm{~h}$. 
A fermentação endógena em Saccharomyces cerevisiae, é processo metabólico de conversão de carboidratos de reserva em etanol, na ausência de substratos exógenos. Ferreira et al. (1999), citaram que a fermentação endógena é um processo, no qual a levedura mobiliza os seus carboidratos de reserva (trealose e glicogênio) para a formação de álcool, como fonte alternativa para obtenção de energia para sua sobrevivência.

Segundo Alcarde \& Basso (1997) a trealose e o glicogênio já foram considerados apenas substâncias de reserva energética para a levedura, mas atualmente diversos autores sugerem que a trealose possua função de proteção para a célula de levedura quando esta se encontra em uma situação de estresse, como altas temperaturas, choque osmótico, efeitos tóxicos do etanol e desidratação; sendo assim, o glicogênio seria então o principal carboidrato de reserva em leveduras. Um ponto importante foi destacado por Lillie \& Pringle (1980) quando observaram que um composto para ser considerado de reserva ele deve ser acumulado em condições nas quais as fontes externas de nutrientes sejam abundantes para serem utilizados em períodos desfavoráveis, fato este que não ocorre com a trealose, acumulada durante a fase lag da diauxia, quando o meio se encontra quase exaurido em glicose. Alcarde \& Basso (1997) verificaram que o acúmulo de trealose estava relacionado a períodos de reduzida taxa de crescimento, sendo que Lillie \& Pringle (1980), mostraram que aumentando-se a disponibilidade de nitrogênio no meio fermentativo, havia menor acúmulo de trealose. Stupiello \& Horii (1981) citaram que em condição de limitação de nitrogênio, há também limitação do crescimento e consequentemente, pode-se ter uma significativa parte de glicose convertida em reserva como glicogênio.

Segundo Martin et al. (1986) o aspecto de proteção exercido pela trealose está relacionado com o fato de que as membranas podem, na presença de trealose, serem dessecadas, sem perder a sua integridade estrutural e funcional. 


\subsubsection{Glicogênio}

O glicogênio proveniente de células animais ou de microrganismos, é composto de moléculas com múltiplas ramificações, de alto peso molecular, com numerosas cadeias compostas de D-glicose com ligações $\alpha(1 \rightarrow 4)$. Estas cadeias contém, normalmente, uma média de 12 resíduos D-glicose, sendo que, individualmente, as cadeias variam consideravelmente de comprimento (Manners, 1971).

O modelo da molécula de glicogênio compõe-se de unidades de glicose ligadas por ligações glicosídicas $\alpha(1$ - 4) e $\alpha(1$ - 6), sendo as cadeias de dois tipos, $\mathrm{A}$ e $\mathrm{B}$. As cadeias do tipo $\mathrm{A}$, se ligam à molécula por ligações $\alpha$ (1 - 6), não sofrendo ramificações e sendo sempre exteriores. As cadeias do tipo $B$, ou cadeias principais, são constituídas por ligações $\alpha(1$ - 4) e ramificadas por cadeias do tipo A (Leão, 1972).

O glicogênio foi extraído pela primeira vez, em 1857, por Claude Bernard e estudado posteriormente por Meyer em 1943 (Leão, 1972).

De acordo com Trevelyan \& Harrison (1956b), o método de extração de carboidratos de células de leveduras, pelo processo de fracionamento, forma distintamente uma fração de glicogênio alcali e outra ácida solúvel. Berck \& Rothstein (1957), afirmam que as duas formas de glicogênio (solúvel e insolúvel) são quimicamente idênticas sendo, deste modo, a fração ácida solúvel apenas uma etapa da extração alcalina, desaparecendo no momento que se utiliza alcali forte para a extração.

\subsubsection{Acúmulo de glicogênio em leveduras}

Para que a biossíntese de glicogênio possa ocorrer, necessita-se de duas enzimas distintas, sendo uma responsável pela formação de ligações glicosídicas $\alpha(1-4)$ e outra pela formação de ligações $\alpha$ (1-6). De uma forma resumida, a biossíntese de glicogênio acontece da seguinte maneira: 
fosforilação da glicose pela hexoquinase; conversão da glicose - 6 - fosfato em glicose - 1 - fosfato; formação da uridil - difosfato - glicose pela pirofosforilase; ação combinada da glicogênio sintase e enzima ramificadora (Ferreira, 1998)

Segundo Quain et al. (1981), Saccharomyces cerevisiae quando submetidas a uma fermentação alcoólica (com adição de ar saturado), apresentam-se, da seguinte maneira, em relação às duas formas de glicogênio: o glicogênio solúvel básico não sofre significativas mudanças ficando em torno de $5 \%$ do peso seco da levedura; o glicogênio ácido solúvel apresenta-se em três diferentes fases durante a fermentação, que são: a) nas duas horas iniciais, antecedendo o crescimento, a concentração cai de $40 \%$ para $6 \%$ do peso seco da levedura; b) na fase de crescimento da levedura ocorre um acúmulo deste polissacarídeo, chegando a teores comparáveis ao inicial; c) quando as leveduras param de crescer, o glicogênio vai diminuindo, lentamente.

\subsubsection{Mobilização de glicogênio em leveduras}

Segundo Ferreira (1998), em células animais, a degradação do glicogênio é controlada pelo $\mathrm{AMP}_{\mathrm{c}}$ (adenosina - 5 - monofosfato cíclico) e realizada pela enzima fosforilase, sabendo-se que esta existe em duas formas interconversíveis: a forma fosforilada ativa (fosforilase a) e a forma desfosforilada inativa (fosforilase $\underline{b}$ ), sendo que a remoção do grupo fosfato da fosforilase a é realizada pela ação de uma fosforilase, resultando fosforilase b, sendo esta refosforilada por uma fosforilase quinase, a qual é ativada pelo $\mathrm{AMP}_{\mathrm{C}}$. Mas, em leveduras, a situação é diferente, pois segundo Sagartia et al. (1971) citados por Gomes (1988), a enzima fosforilase não é $\mathrm{AMP}_{c}$ sensível,

não ocorrendo em duas formas ( $\underline{a}$ e $\underline{b}$ ), sendo inibida competitivamente "in vitro" pela G-6-P, UDP glicose e glicose. No entanto, estes metabólicos não regulam a atividade da fosforilase "in vivo", deste modo sugeriu-se que a não atuação dos inibidores competitivos "in vivo", deve-se ao fato da fosforilase estar ligada, 
de maneira saturada, às partículas de glicogênio, sendo a concentração de grupos terminais na molécula, muito elevada.

Segundo Quain et al. (1981), no momento inicial da fermentação, com oxigênio presente no meio fermentativo (até $2 \mathrm{~h}$ ) o açúcar não foi consumido pela levedura; neste momento ocorre um aumento substancial da síntese de lipídeos, assim os autores concluiram que o glicogênio foi a única fonte de energia metabólica para as leveduras.

\subsubsection{Trealose}

Segundo Wiemken (1990) a trealose (1- $\alpha$-D-glucopiranosil - $\alpha-D$ glucopiranosídeo), cuja designação é oriunda de um confeito denominado "trehala manna" produzido da pupa de um besouro que vivia no deserto, é um dissacarídeo não redutor.

Em Matiazi (1995) encontramos citação sobre a trealose de que teria sido primeiramente isolada da ferrugem do centeio por Wiggers, em 1832. A trealose foi extraída de células de levedura por Koch \& Koch, em 1925 (Manners, 1971 e Matiazi, 1995).

A trealose é encontrada em diversos organismos na natureza, tendo sido isolada nos fungos, tanto no esporo destes como nas formas vegetativas. É um importante carboidrato de reserva nos ovos, larvas e pupas de insetos, tendo também nos fungos outra função, ou seja, carboidrato de proteção contra agentes estressantes (Gutierrez, 1997).

Atualmente, em relação à função da trealose, é mais aceito que ela exerça um papel de proteção às células quando as mesmas se encontram em período de estresse, descartando-se assim a hipótese de que ela exerça a função de carboidrato de reserva (Matiazi, 1995). 


\subsubsection{Acúmulo de trealose em leveduras}

O mecanismo de biossíntese de trealose em levedura de cervejaria, envolve a transferência do resíduo de D-glicose do nucleotídeo UDP - glicose para glicose - 6 - P, através da ação da enzima trealose- 6-fostafo sintase, formando trealose-6-fosfato e uridina fosfato, sendo que a remoção do grupo fosfato da trealose-6-P para liberação de trealose, é realizada por fosfatase específica (trealose-6-P fosfatase) (Cabib \& Leloir, 1958).

Segundo Leão (1972), as leveduras em condições não proliferantes, apresentaram síntese de trealose, utilizando glicose como fonte externa de carbono.

Suomalainen \& Pfaffli (1961) demonstraram que em leveduras, a síntese de trealose é favorecida por condições aeróbias, em relação a anaeróbias. No entanto, Alcarde \& Basso (1997) conseguiram, em anaerobiose, através de uma solução tampão de citrato de potássio $2 \mathrm{M}, \mathrm{pH}=4$, acrescida de $2 \%$ de glicose, com tratamento de $45^{\circ} \mathrm{C}$ por $2 \mathrm{~h}$, obter um acúmulo de trealose de 0,85 para 6,33 mg por $100 \mathrm{mg}$ de matéria seca, em cepas TA (M300-A) de Saccharomyces cerevisiae; o mesmo ocorreu com Gutierrez (1990) que através de uma fermentação alcoólica em meio anaeróbio, obteve resultados de até $14,97 \mathrm{~g}$ de glicose por $100 \mathrm{~g}$ de matéria seca.

Num processo fermentativo e logo após a inoculação, as leveduras apresentaram mobilização parcial da trealose acompanhada de aumento da taxa de fermentação, sendo que a menor quantidade de trealose coincidiu com a máxima taxa de fermentação. Posteriormente à mobilização, ocorreu um período de ressíntese, o qual foi interrompido pela exaustão do substrato fermentável, e um comportamento estável da trealose após este processo. Quando as leveduras foram inoculadas em diversos meios fermentativos com a presença de glicose, houve no início, aumento da taxa de fermentação e mobilização da trealose na levedura, sendo posteriormente observado onde se omitiu o nitrogênio, apreciável ressíntese de trealose em relação aos outros; 
isto se deve a inibição da ressíntese deste carboidrato, em presença de nitrogênio assimilável (Trevelyan \& Harrison, 1956a).

Segundo Thevelein (1984), as células de leveduras quando se encontram em fase de crescimento exponencial em glicose, contém baixas concentrações de trealose.

As leveduras expostas a uma fermentação prévia, em meio com glicose e ausência de nitrogênio, sofreram mobilização da trealose, com posterior ressíntese (decréscimo parcial da reserva de aminoácido), alcançando aos 80 minutos de fermentação teores semelhantes ao inicial, e neste momento, as leveduras ao serem expostas a um meio fermentativo, sem adição de nitrogênio, não apresentaram a fase de mobilização, ocorrendo aumento do teor de trealose. Este fato também aconteceu quando as leveduras, ao invés de realizar uma fermentação prévia sem nitrogênio, foram inoculadas em um meio completo, e aos 60 minutos, as reservas de nitrogênio foram mantidas, mas ao serem colocadas em meio com ausência de nitrogênio, ocorreu aumento do teor de trealose, porém inferior ao obtido no primeiro nas duas horas iniciais de fermentação (Trevelyan \& Harrison, 1956a).

Durante a fermentação, utilizando levedura de panificação, ocorreram pequenas variações em carboidrato solúvel em ácido tricloroacético, do qual, o principal constituinte é a trealose. O fator considerado responsável por este metabolismo, foi a baixa concentração de glicose presente no meio, cerca de $5 \mathrm{mM}$, a qual teria restringido a síntese de trealose (Trevelyan et al., 1952).

Segundo Gutierrez (1990), as leveduras de panificação Saccharomyces cerevisiae e Saccharomyces uvarum IZ 1904, apresentaram aumento no acúmulo de trealose com maiores concentrações de sacarose no meio. Enquanto a Saccharomyces cerevisiae M-300-A teve uma redução de trealose quando o meio variou de 8 para $11 \%$ de sacarose e um aumento quando exposta a 11 para $16 \%$ de sacarose.

Mas Alcarde \& Basso (1997) verificaram que o acúmulo de trealose ocorreu devido ao estímulo de um agente estressante, dependendo do tempo 
de exposição, sendo este fato demonstrado por vários autores que conseguiram, em tratamento térmico, com aumento de temperatura de $23-30^{\circ}$ para $36-45^{\circ} \mathrm{C}$, proporcionar o estímulo ao acúmulo de trealose endógena em leveduras.

Hottiger et al. (1987) observaram que Saccharomyces cerevisiae quando submetida a elevação de temperatura de $27^{\circ} \mathrm{C}$ para $40^{\circ} \mathrm{C}$, promovia maior acúmulo de trealose mas ao se retornar à temperatura inicial, ocorria uma diminuição do nível de trealose na mesma.

Gutierrez (1990), verificou alterações nos teores de trealose, quando as leveduras foram submetidas a diferentes valores de $\mathrm{pH}$, como aconteceu com a levedura Saccharomyces M-300-A e de panificação (Saccharomyces cerevisiae), que em fermentações com $\mathrm{pH} 4,5$, mostrou maiores teores de trealose do que em fermentações conduzidas a pH 3,0, tendo ocorrido o inverso com a levedura Saccharomyces uvarum IZ-1904.

\subsubsection{Mobilização de trealose em leveduras}

Em Saccharomyces cerevisiae a enzima responsável pela degradação da trealose é a trealase. Esta enzima, afirmaram Keller et al. (1982), está localizada em vacúolos enquanto a trealose, no citosol. Ferreira (1998) destacou que em Saccharomyces cerevisiae, é conhecida apenas uma enzima capaz de hidrolisar a ligação glicosídica da molécula de trealose, a trealase ( $\alpha . \alpha$. trealose-1-D-glicoidrolase)

Segundo Soumalainen \& Pfaffli (1961), a maior viabilidade celular e a atividade da levedura eram decorrentes de elevado teor de trealose; deste modo, a função do mesmo seria de proteção as células contra a autólise.

Após fermentação da glicose por 80 minutos, em meio com ausência de nitrogênio, as leveduras ressintetisaram, aproximadamente, o total de trealose perdida no período de mobilização inicial, no entanto, no momento em 
que foi adicionado cloreto de amônio (nitrogênio assimilável), este ocasionou declínio do teor de trealose (Trevelyan \& Harrison, 1956a).

\subsection{Viabilidade celular em leveduras}

Alguns fatores podem modificar o desenvolvimento da fermentação alcoólica, como a temperatura que afeta a velocidade de crescimento e fermentação, sendo os controles para estes efeitos dependentes de fatores nutricionais e genéticos (Laluce, 1991). Gutierrez (1991) observou que a levedura Fleischmann (Saccharomyces cerevisiae) multiplicada em condições anaeróbias, com adição de ergosterol e ácidos graxos insaturados, apresenta em fermentação à temperatura de $30^{\circ} \mathrm{C}$, viabilidade celular maior que à temperatura de $35^{\circ} \mathrm{C}$, e que tal fato ocorreu com os teores de $32 ; 48 ; 60$ e 120 ppm de ácido linoléico e 5 ppm de ergosterol, e também foi constatado aumento na viabilidade celular com doses crescentes de ácido linoléico, em ambas as temperaturas.

Marques (1997) em ensaios enfocando concentração celular (Tabela 6) e viabilidade celular (Tabela 7) em leveduras Saccharomyces cerevisiae utilizando mosto com $310 \mathrm{~g}$ de ART/L em 8 fermentações consecutivas, com inóculo separado em 2 tratamentos, um convencional, tratado com vinho e um denominado beneficiado, tratado com água, encontrou resultados, mais positivos, para o inóculo beneficiado em relação ao convencional, em ambos os experimentos, mas foi verificada uma queda acentuada de viabilidade celular nos dois inóculos, não explicada pelo autor. 
Tabela 6. Resultados de concentração celular ( $\mathrm{g} / \mathrm{L})$, em ensaios com mosto de $310 \mathrm{~g} \mathrm{ART/L}$, com 3 repetições.

\begin{tabular}{|c|c|c|}
\hline Ordem da Fermentação & \multicolumn{2}{|c|}{ Concentração celular (g/L) } \\
\hline & Inóculo convencional & Inóculo beneficiado \\
\hline $1^{\circ}$ & $39,73^{\mathrm{A} \mathrm{a}}$ & $39,73^{\mathrm{A} a b}$ \\
\hline $2^{\circ}$ & $29,79^{\mathrm{B}} \mathrm{C}$ & $34,77^{A ~ c d}$ \\
\hline $3^{\circ}$ & $22,44^{\mathrm{Bd}}$ & $33,29^{A d}$ \\
\hline $4^{\circ}$ & $20,22^{B d}$ & $36,76^{\mathrm{A} \mathrm{bcd}}$ \\
\hline $5^{\circ}$ & $27,09^{B c}$ & $37,90^{\mathrm{Abc}}$ \\
\hline $6^{\circ}$ & $35,20^{A b}$ & $38,64^{\mathrm{A} a b c}$ \\
\hline $7^{\circ}$ & $37,78^{\mathrm{A} a b}$ & $40,64^{\mathrm{A} \mathrm{ab}}$ \\
\hline $8^{\circ}$ & $35,61^{\mathrm{B} \text { ab }}$ & $42,47^{\mathrm{A} a}$ \\
\hline Médias & $30,98^{\mathrm{B}}$ & $38,02^{A}$ \\
\hline
\end{tabular}

Fonte: Marques (1997)

Letras maiúsculas diferentes na linha e letras minúsculas diferenças na coluna a $5 \%$ de probabilidade pelo teste de Duncan.

Saccharomyces uvarum IZ 1904, foi submetida a 6 ciclos fermentativos, utilizando-se meio de HTM (High Test Molasses) com adição de $3 \mathrm{~g} / \mathrm{L}$ de óleo de soja. Foi constatado em meio com adição do óleo, um nível mais elevado do teor de glicogênio na levedura, um comportamento mais equilibrado entre o acúmulo e a mobilização de trealose durante os ciclos e uma amplitude de variação na concentração dos carboidratos de reserva mais homogênea, durante a acumulação e mobilização. Levando-se em consideração este comportamento relacionado às reservas, pode-se concluir que esta seja a causa da maior viabilidade celular mantida por células cultivadas na presença de óleo de soja (Duarte et al., 1997).

De acordo com Ball \& Atkinson (1975), a perda de viabilidade de células, em condições aeróbias, está diretamente relacionada com o consumo de reservas por estas células. 
Tabela 7. Viabilidade celular (\%), nos ensaios com mosto de $310 \mathrm{~g} \mathrm{ART/L,} \mathrm{com}$ 3 repetições.

\begin{tabular}{ccc}
\hline Ordem da Fermentação & \multicolumn{2}{c}{ Viabilidade celular $(\%)$} \\
\hline $1^{\circ}$ & Inóculo convencional & Inóculo beneficiado \\
$2^{\circ}$ & $91,17^{\mathrm{A} \mathrm{a}}$ & $91,17^{\mathrm{A} \mathrm{a}}$ \\
$3^{\circ}$ & $19,29^{\mathrm{Bc}}$ & $58,65^{\mathrm{A} \mathrm{b}}$ \\
$4^{\circ}$ & $26,59^{\mathrm{Ac}}$ & $30,35^{\mathrm{A} \mathrm{d}}$ \\
$5^{\circ}$ & $29,70^{\mathrm{Bc}}$ & $54,75^{\mathrm{A} \mathrm{b}}$ \\
$6^{\circ}$ & $27,75^{\mathrm{Ac}}$ & $35,73^{\mathrm{A} \mathrm{d}}$ \\
$7^{\circ}$ & $26,18^{\mathrm{Bc}}$ & $50,50^{\mathrm{Abc}}$ \\
$8^{\circ}$ & $46,60^{\mathrm{Ab}}$ & $38,47^{\mathrm{Acd}}$ \\
Médias & $22,32^{\mathrm{Bc}}$ & $57,61^{\mathrm{A} \mathrm{b}}$ \\
\hline
\end{tabular}

Fonte: Marques (1997)

Letra maiúsculas diferenças na linha e letras minúsculas diferenças na coluna à $5 \%$ de probabilidade pelo teste de Duncan.

Amorim \& Gomes (1988) descreveram os tratamentos adotados para se fazer a conservação das leveduras, durante uma interrupção no processo fermentativo, às temperaturas de 25,30 e $40^{\circ} \mathrm{C}$ e em condições de $\mathrm{pH}$ de $2 ; 2,5$ e 3. Os resultados levaram os autores a concluir que houve pouca influência na viabilidade e na capacidade fermentativa, até um período de $6 \mathrm{~h}$ de tratamento.

Segundo Wilson \& Mcleod (1976), a diminuição da viabilidade das leveduras quando estas se encontram em jejum, não é devida à deficiência de reservas endógenas mas sim é ocasionada pelas alterações das funções das membranas, pela deficiência de esteróides e ácidos graxos insaturados, uma vez que, na constituição das membranas celulares, estão presentes componentes como as proteínas e fosfolipídios; podem ser os ácidos graxos responsáveis pela formação dos fosfolipídios, saturados e insaturados. 


\section{4 Óleo vegetal em leveduras}

Segundo Gutierrez \& Silva (1993), o álcool no Brasil, é produzido basicamente a partir do caldo e melaço de cana de açúcar, os quais são ricos em ácido linoléico, sendo este o principal ácido graxo encontrado no melaço de cana-de-açúcar, nos teores de aproximadamente $42 \%$ do total de ácidos graxos.

Brown \& Rose (1969), afirmaram que a composição dos ácidos graxos dos microrganismos varia com a espécie do microrganismo, idade da cultura, temperatura e composição do meio de cultura.

O teor de lipídios totais das leveduras varia, largamente, com as espécies, sendo que em geral é possível reconhecer dois grupos: o primeiro grupo que enquadra a maioria das leveduras, e apresenta entre 7 e $15 \%$ do peso seco; e o segundo grupo, às vezes chamado de "fat yeasts", que contém de $30 \%$, até acima de $60 \%$ do peso seco (Hunter \& Rose, 1971 e Halász \& Lásztity, 1991). A composição de ácidos graxos é caracterizada pela presença de um alto teor de ácidos graxos insaturados, sendo o fluxo de oxigênio durante a etapa de cultivo das células, o parâmetro que mais influencia a composição de ácidos graxos (Halász \& Lásztity, 1991).

Andreasen \& Stier (1953) citado por Gutierrez (1991) destacaram que as leveduras Saccharomyces exigem para sua multiplicação, em meio anaeróbio, da presença de ácidos graxos insaturados e ergosterol. Bloomfield \& Bloch (1960), afirmaram que a dessaturação de ácidos graxos necessita da presença de oxigênio molecular, este não podendo ser substituído por outros aceptores de elétrons. Gutierrez (1991), em sua pesquisa com adição de ergosterol e ácidos graxos insaturados, em meio anaeróbico, obteve formação de ácidos graxos insaturados como palmitoleico e oleico, isto devido provavelmente a diminutas quantidades de oxigênio dissolvido no meio. Leveduras utilizadas para produção de álcool em destilarias, não são capazes de produzir ácidos graxos poliinsaturados como linoleico e linolênico, mas 
produzem acidos oleico e palmitoleico (Bendová et al., 1991). Resende \& Alterthum (1986) relataram que as leveduras foram capazes de absorver os ácidos graxos que se encontravam no meio fermentativo.

De acordo com Alterthum \& Cruz (1987), em escala industrial, na fermentação alcoólica, o oxigênio dissolvido no meio é consumido em pouco tempo, sendo que em sua ausência, a levedura se torna incapaz de sintetisar ácidos graxos insaturados e esteróis essenciais, necessários para a manutenção da membrana citoplasmática, em boas condições fisiológicas.

Segundo Gutierrez \& Silva (1993), as leveduras Saccharomyces cerevisiae M-300-A e Saccharomyces uvarum IZ -1904 quando submetidas à multiplicação, em meio fermentativo de melaço, foram capazes de incorporar ácidos graxos, sendo encontrado, nestas leveduras, predominância de ácido linoléico e palmítico.

Carvalhal et al. (1980), constataram que Saccharomyces cerevisiae, quando submetidas a cultivo, em anaerobiose, com fornecimento de esterol e ácidos graxos insaturados (esterol: ergosterol, stigmasterol, $\beta$-sitosterol e colesterol; ácidos graxos: oleico, linoleico e linolênico), conseguiram incorporálos às membranas citoplasmáticas.

Durante a fermentação alcoólica, mínimas quantidades de oxigênio ou uma adequada quantidade de ácidos graxos insaturados no meio fermentativo podem restaurar a atividade celular das leveduras e a produtividade em etanol (Hayashida et al., 1974). Por outro lado, Duarte et al. (1997), verificaram que na ausência de oxigênio - uma condição que é provocada pela fermentação - as células são incapazes de crescer, pois elas não sintetisam ácidos graxos insaturados e esterol.

Ainda, em Gutierrez et al. (1990), as leveduras quando cultivadas em meio aeróbio, apresentaram grandes quantidade dos ácidos graxos insaturados palmitoleico e oleico, não tendo sido detectado ácido linoleico, havendo menor formação de ácidos graxos de cadeia curta; já em meio anaeróbio, houve principalmente a formação de ácido palmitico acompanhado de grandes 
quantidades de ácidos graxos de cadeia curta. No caso de meio anaeróbio, com adição de ácidos graxos saturados e insaturados, a levedura teve a capacidade de absorvê-los e incorporá-los.

Segundo Quain (1988), em células de leveduras, baixos níveis de glicogênio limitam o potencial para nova síntese de lipídios; a deficiência de glicogênio, fez com que houvesse problemas relacionados à viabilidade celular durante o processo fermentativo, fato diretamente relacionado à insuficiência na síntese de lipídios. A dimensão e natureza da saturação das cadeias foi uma resposta altamente dependente das condições prévias de cultura do microrganismo considerado. E, em Alterthum \& Cruz (1987) encontramos que em temperaturas elevadas, ocorre a formação de cadeias carbônicas saturadas e longas, enquanto que em temperaturas baixas, há a formação de componentes com maior grau de insaturação e menor comprimento das cadeias. $\mathrm{Na}$ levedura cultivada a temperatura de $30^{\circ} \mathrm{C}$, os principais ácidos graxos insaturados são o palmitoleico e oleico, sendo que os saturados são palmítico e esteárico.

Fonseca \& Gutierrez (1974) destacaram que o óleo de soja é rico em ácido linoleico e Alterthum \& Cruz (1987), relataram um aumento do rendimento da fermentação alcóolica com a adição do mesmo.

De acordo com Duarte et al. (1997), foram encontrados altos valores médios de viabilidade celular nas leveduras expostas à fermentação com $3 \mathrm{~g} / \mathrm{L}$ de óleo de soja, em relação às leveduras em condições fermentativas, sem adição do mesmo; assim no primeiro caso, encontraram um valor de viabilidade celular de $77 \%$ ao final do sexto ciclo fermentativo, contra uma viabilidade de $65 \%$ do segundo.

Os ácidos graxos estão diretamente relacionados à composição das membranas celulares das leveduras, sendo que Quastel (1967) aponta que a proporção de um saturado para dois insaturados seria considerado ideal, para produzir uma necessária porosidade, fluidez e estabilidade das membranas. 
Thomas \& Rose (1979), observaram que as membranas de células ricas em ácidos graxos saturados, mostraram-se menos permeáveis ao etanol, deste modo, conclue-se que células ricas em insaturações liberam mais etanol ao meio.

\subsection{Condições não favoráveis à proliferação}

Os métodos de preservação tem como finalidade manter a viabilidade e a estabilidade dos organismos e para alcançar esta condição, por um longo período, necessita-se de uma paralisação ou o retardamento do metabolismo celular. Para conseguir atingir estas condições, tem-se utilizado de diversos processos que se constituem nos métodos de conservação, dentre os quais se destacam: subcultivo ou repiques sucessivos, secagem ou desidratação, congelamento e liofilização (Alcarde \& Basso, 1997).

Suomalainen \& Pfaffli (1961) verificaram, que leveduras de panificação, durante período de armazenamento, mantiveram sua viabilidade celular, devido a trealose.

Segundo Alcarde \& Basso (1997), o acúmulo da trealose endógena pelas leveduras proporcionou uma maior taxa de manutenção da viabilidade celular, após o processo de desidratação por liofilização, em comparação com as leveduras que não passaram pelo processo de acúmulo de trealose.

Trevelyan \& Harrison (1956a), destacaram que a levedura em meio com ausência de substratos fermentáveis, apresentava estabilidade do conteúdo de trealose.

Quando uma suspensão de leveduras é exposta a uma condição de repouso em água ácida, há uma grande dificuldade para se estabelecer uma correlação entre a diminuição de viabilidade e as quantidades de carboidratos de reserva; isto se deve, possivelmente, ao fato que os tratamentos efetuados afetaram muito pouco o fermento, podendo ser devido ao curto tempo de tratamento $(6 \mathrm{~h})$. Mas, verifica-se que ocorreu uma discreta queda nos teores 
de trealose, em temperaturas de 25 e $40^{\circ} \mathrm{C}$, principalmente em pH mais baixos, e que os teores de glicogênio permaneceram inalterados, enquanto a $30^{\circ} \mathrm{C}$ observou-se, após $6 \mathrm{~h}$ de tratamento, valores praticamente iguais de trealose. Com tempos de tratamento mais prolongados, foi demonstrado a ocorrência de quedas significativas nos teores de trealose (Amorim \& Gomes, 1988).

Saccharomyces cerevisiae quando mantida na ausência de substrato, estaticamente, em pH entre $4,5-5,5$ e à temperaturas de $32^{\circ} \mathrm{C}, 36^{\circ} \mathrm{C}$ e $42^{\circ} \mathrm{C}$, numa concentração de $50 \%$ e $20 \%$ p/v de células por um período de $72 \mathrm{~h}$, apresentou (a $50 \%$ p/v de levedura), em $8 \mathrm{~h}$ de fermentação endógena, teores de $43,6 \%$ e $43 \%$ respectivamente de proteína nas temperaturas de $36^{\circ} \mathrm{C}$ e $42^{\circ} \mathrm{C}$; e que após $72 \mathrm{~h}$, a temperatura de $32^{\circ} \mathrm{C}$ o teor protéico foi superior $(44,1$ $\%)$ a qualquer tempo e temperatura e inferior $(37,8 \%)$ a $42^{\circ} \mathrm{C}$. Isto está relacionado a autólise nas temperaturas mais elevadas em maior tempo, indicado pela elevação de proteína solúvel na suspensão de levedura, 1,26 \% a $36^{\circ} \mathrm{C}, 1,61 \%$ a $42^{\circ} \mathrm{C}$ e $0,78 \%$ a $32^{\circ} \mathrm{C}$. O teor de etanol (no meio) foi relacionado com o alto teor protéico, $0,1 \%$ a $32^{\circ} \mathrm{C}, 0,08 \%$ a $36^{\circ} \mathrm{C}$ e $0,06 \%$ a $42^{\circ} \mathrm{C}$. A biomassa seca permaneceu constante em $11 \%$ a $32^{\circ} \mathrm{C}$ pelo período de $72 \mathrm{~h}$, enquanto que em temperaturas mais elevadas ocorreu um decréscimo deste valor, sendo este fato correlacionado com a diferença de viabilidade celular, $32^{\circ} \mathrm{C}(48,5 \%), 36^{\circ} \mathrm{C}(3,3 \%)$ e $42^{\circ} \mathrm{C}(10,1 \%)$; na suspensão $20 \% \mathrm{p} / \mathrm{v}$ foi encontrado um menor teor protéico a $42 \%$ a $36^{\circ} \mathrm{C}$ e $42^{\circ} \mathrm{C}$ em $8 \mathrm{~h}$ de fermentação e $42,9 \%$ a $32^{\circ} \mathrm{C}$ com 72 h (Nogueira \& Oliva Neto, 2000)

Nos processos de desidratação-hidratação e congelamentodescongelamento, tem-se modelos que explicam o efeito de proteção da trealose na membrana da célula de levedura. O modelo que merece destaque é o de Crowe et al. (1984), que aponta uma interação entre trealose e grupos polares das cadeias fosfolipídicas existentes na membrana. Neste caso, a água ligada aos terminais polares dos fosfolipídios em condições favoráveis, seria substituída pela trealose, em uma situação de estresse. Com esta substituição 
seria evitada as separações laterais dos componentes das membranas, pois não haveria assim alterações do espaçamento entre os fosfolipídios. Devido à substituição das moléculas de água pela de trealose, não teríamos a passagem de fase fluída para fase gel da membrana e desta forma, se manteria a integridade e a fluidez da membrana, consequentemente, a viabilidade celular. 


\section{MATERIAL E MÉTODOS}

\subsection{Microrganismo}

O microrganismo utilizado nesta pesquisa, foi uma linhagem de levedura, espécie Saccharomyces cerevisiae Y904, cedida pela Mauri do Brasil - Pederneiras - SP.

\subsection{Meios de cultura}

\subsubsection{Meios de manutenção e de reativação das células desidratadas}

Para a realização do experimento, foi necessária a utilização de dois meios de cultura (Tabela 8 e 9), com a função de manutenção e reativação das células desidratadas.

Tabela 8. Meio de cultura YEPD ágar "Yeast extract peptone dextrose agar" para manutenção da linhagem e plaqueamento.

\begin{tabular}{cc}
\hline & Composição \\
\hline Extrato de levedura & $10 \mathrm{~g}$ \\
Peptona & $10 \mathrm{~g}$ \\
Dextrose & $20 \mathrm{~g}$ \\
Ágar & $15 \mathrm{~g}$ \\
$\mathrm{H}_{2} \mathrm{O}$ destilada & $1.000 \mathrm{~mL}$ \\
\hline
\end{tabular}

Fonte: (Ribeiro, 1997) 
Tabela 9. Meio de cultivo YEPD líquido "Yeast extract peptone dextrose" para reativação da linhagem comercial.

\begin{tabular}{cc}
\hline & Composição \\
\hline Extrato de levedura & $10 \mathrm{~g}$ \\
Peptona & $10 \mathrm{~g}$ \\
Dextrose & $20 \mathrm{~g}$ \\
$\mathrm{H}_{2} \mathrm{O}$ destilada & $1.000 \mathrm{~mL}$ \\
\hline
\end{tabular}

Fonte: (Ribeiro, 1997)

Os meios foram esterilizados em autoclave a uma atmosfera de pressão, a $121^{\circ} \mathrm{C}$ durante 15 minutos.

\subsubsection{Meio de cultivo para fermentação}

As células desidratadas, foram reativadas no meio 3.2.1 e inoculadas em alíquotas de $10 \mathrm{~mL}$ para fermentação em meio YEPS por $24 \mathrm{~h}$, para ocorrer o processo fermentativo.

Tabela 10. Meio de cultivo YEPS "Yeast extract peptone sucrose" para fermentação.

\begin{tabular}{cc}
\hline & Composição \\
\hline Extrato de levedura & $10 \mathrm{~g}$ \\
Peptona & $10 \mathrm{~g}$ \\
Sacarose & $100 \mathrm{~g}$ \\
$\mathrm{H}_{2} \mathrm{O}$ destilada & $1.000 \mathrm{~mL}$ \\
\hline
\end{tabular}

Os meios de cultivo, passaram por um processo de esterilização idêntico ao do ítem 3.2.1. 


\subsection{Verificação da pureza da levedura comercial desidratada}

\subsubsection{Reativação da cultura desidratada para isolamento}

As leveduras foram isoladas a partir da linhagem comercial de Saccharomyces cerevisiae Y904, com o objetivo de se obter cultura pura.

Para se iniciar o processo de isolamento das leveduras, foi necessária sua reativação, a qual ocorreu em tubos de cultura esterilizados contendo $5 \mathrm{~mL}$ de meio de cultivo YEPD líquido esterilizado (alça de Henle, em número de 3), e incubados a $28 \pm 1^{\circ} \mathrm{C}$ durante $24 \mathrm{~h}$.

\subsubsection{Isolamento e purificação das culturas de leveduras}

Foram realizadas diluições em série a partir das culturas reativadas e estas foram conduzidas até $10^{-6}$, com água destilada esterilizada. $O$ plaqueamento em meio de cultura YEPD ágar esterilizado, foi feito pela técnica de "spread plate" e incubadas a $28 \pm 1^{\circ} \mathrm{C}$ por $72 \mathrm{~h}$.

As leveduras foram avaliadas quanto a morfologia, a fim de se verificar a taxa de possíveis contaminantes que apresentassem diferenciação ao menos de morfologia. 

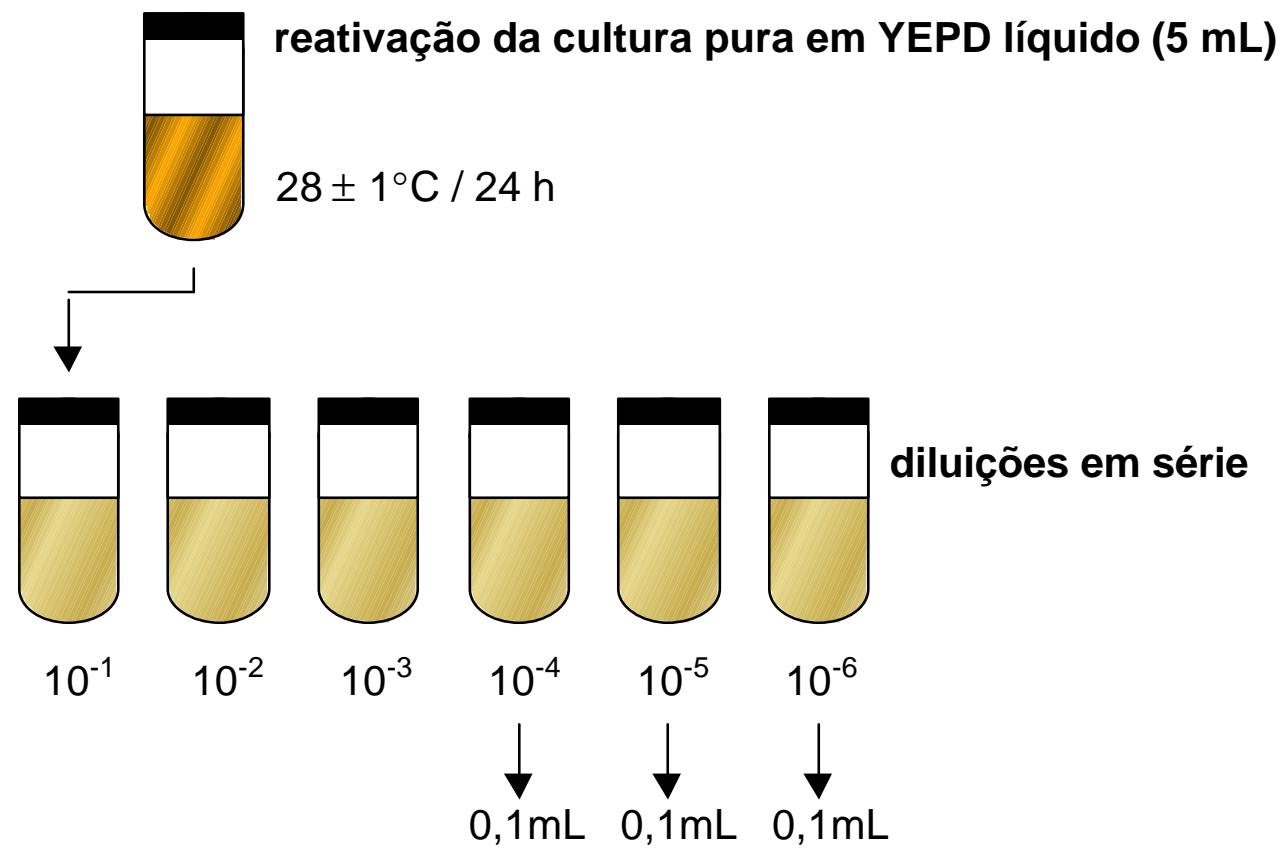

plaqueamento: distribuição

com espátula de Drigalsky em YEPD ágar
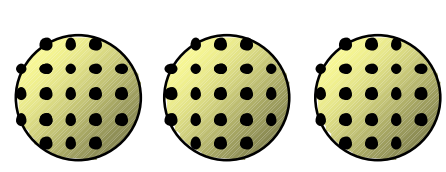

$28 \pm 1^{\circ} \mathrm{C} / 72 \mathrm{~h}$

diluições em série

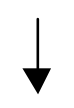

inoculação em YEPD ágar inclinado $(5 \mathrm{~mL})$

$28 \pm 1^{\circ} \mathrm{C} / 24-48 \mathrm{~h}$

cultura pura

armazenada

Figura 1 - Metodologia para isolamento e purificação de leveduras.

\subsection{Fermentação e obtenção das leveduras para análise}

A reativação e propagação de leveduras foi efetuada com inoculação de $25 \mathrm{~g}$ da levedura desidratada em $1000 \mathrm{~mL}$ de meio YEPD líquido esterilizado, e incubado à temperatura de $30 \pm 1^{\circ} \mathrm{C}$ por $24 \mathrm{~h}$. Após este período, foram retiradas amostras, para quantificação de unidades formadoras de colônias e viabilidade celular das leveduras, sendo a seguir retiradas alíquotas de $10 \mathrm{~mL}$, para servir de inóculo para os frascos contendo o meio de fermentação. 
Eram 54 frascos erlenmeyer de $500 \mathrm{~mL}$ de capacidade, contendo cada um, $200 \mathrm{~mL}$ de meio de cultivo YEPS líquido esterilizado, sendo 27 frascos com adição de $3 \mathrm{~g} / \mathrm{L}$ de óleo de soja comercial. Os frascos foram incubados em "shaker New Brunswick, modelo G53", por 24 h a 90 rpm de agitação, em movimento circular, e temperatura de $30 \pm 1^{\circ} \mathrm{C}$.

Para o processo fermentativo, foi estabelecido um período de $24 \mathrm{~h}$, tempo este suficiente para total consumo do açúcar do meio.

A fermentação foi monitorada por pesagens periódicas dos frascos até obtenção de peso constante (Matiazi, 1995). Além disto, foram realizadas observações da sedimentação no meio fermentativo e acompanhamento do teor de glicose utilizando-se a glicofita.

Completada a fermentação, as células de leveduras, foram coletadas por centrifugação em centrífuga IEC - PR 6000 a 900 g por 5 min, sendo a seguir ressuspensas em $\mathrm{KCl}$ 0,154M esterilizado, contendo Kamoran (3 ppm) e recentrifugadas nas mesmas condições. $O$ sobrenadante da centrifugação, foi armazenado para determinação do teor alcoólico.

\subsubsection{Monitoramento das alterações fisiológicas na suspensão celular}

As massas de levedura obtidas da fermentação em meio com e sem adição de óleo de soja e tratadas conforme descrito no item 3.4, foram agora acompanhadas por 8 dias submetidas a agitação em "shaker", com rotação de $90 \mathrm{rpm}$ e temperatura de $30 \pm 1^{\circ} \mathrm{C}$. Dos 54 frascos foram tomadas amostras onde foram realizadas determinações de contagem de número de unidades formadoras de colônias, viabilidade celular, concentração celular em matéria seca, nitrogênio total na levedura e no meio, carboidrato total, glicogênio e trealose, a cada $24 \mathrm{~h}$, por um período de 8 dias, tendo cada tratamento três repetições. 


\subsection{Análise estatística}

O delineamento experimental utilizado foi inteiramente casualizado, em arranjo fatorial $2 \times 5$, com 3 repetições. $O$ acompanhamento foi realizado até o $7^{\circ}$ ou $8^{\circ}$ dia, entretanto a análise estatística realizada até o $4^{\circ}$ dia em função das alterações fisiológicas ocorridas a partir de então, com desorganização celular. Para o teor alcoólico, utilizou-se o delineamento experimental inteiramente casualizado, com um critério.

\subsection{Tratamentos}

Foi denominado tratamento $T 1$, as células de leveduras que se originaram de uma fermentação prévia sem adição de óleo de soja; e T2, do mesmo modo porém com adição de óleo de soja no meio fermentativo, antes do período de jejum imposto no experimento.

\subsection{Análises físico-químicas e microbiológicas}

\subsubsection{Viabilidade celular}

A determinação de viabilidade celular em células de leveduras, foi realizada através do método por coloração com azul de metileno. (Pierce, 1970).

\subsubsection{Teor alcoólico}

A determinação do teor alcoólico do vinho, foi realizada através da destilação da amostra em um microdestilador, e a leitura da massa específica obtida em um densímetro digital A.PAAR DMA - 45. 


\subsubsection{Concentração de leveduras}

A determinação da concentração de leveduras, foi realizada através dos métodos de determinação da concentração de leveduras por centrifugação (Koshimizu et al., 1982), com verificação através do método de determinação da concentração de leveduras por turbidimetria (Mallette, 1969).

\subsubsection{Nitrogênio total, na matéria seca}

$10 \mathrm{~mL}$ da suspensão de $\mathrm{KCl}$ 0,154M com leveduras, foi transferida para um tubo de centrífuga e submetido a uma temperatura de $20^{\circ} \mathrm{C}$ em banho por 5 min; após este tempo foi centrifugado a $275 \mathrm{~g}$ por $10 \mathrm{~min}$, onde o sobrenadante foi separado para análise de nitrogênio e o sedimentado, foi lavado por sucessivas centrifugações e ressuspensões em água destilada e a seguir foi determinado o teor de nitrogênio na suspensão.

A determinação do nitrogênio total foi realizada pelo método de Kjeldahl, conforme descrição em Silva (1990).

A expressão do teor de nitrogênio total em relação à matéria seca, foi expresso em porcentagem.

\subsubsection{Carboidratos totais}

$10 \mathrm{~mL}$ da suspensão de leveduras em $\mathrm{KCl} 0,154 \mathrm{M}$, foi transferida para um tubo de centrífuga e submetida a um banho a $20^{\circ} \mathrm{C}$ por $5 \mathrm{~min}$; após este tempo foi centrifugado a $275 \mathrm{~g}$ por $10 \mathrm{~min}$, onde o sedimentado, foi lavado com água destilada para posterior análise de carboidrato totais.

A determinação de carboidratos totais na suspensão de leveduras, foi realizada pelo método de antrona descrito em Bacila (1960). 


\subsubsection{Carboidratos de reserva}

\subsubsection{Teor de glicogênio}

O teor de glicogênio endógeno, foi analisado após extração com carbonato de sódio $0,25 \mathrm{M}$ a frio e determinado como glicose, após hidrólise (amiloglucosidase), empregando-se glicose oxidase, peroxidase e a leitura espectofotométrica, em 525 nm (Leão et al.,1984).

\subsubsection{Teor de trealose}

O teor de trealose endógeno, foi analisado através da extração com ácido tricloroacético 0,5M (TCA) a frio, segundo Trevelyan \& Harrison (1956a) e determinada pelo método de antrona com leitura espectrofotométrica a 620nm, segundo Brin (1966).

O teor de trealose em relação ao teor de carboidratos totais na levedura, foi expresso em porcentagem.

\subsubsection{Levedura referência}

Uma alíquota contendo $8 \mathrm{~g}$ de leveduras desidratadas, recém amostradas do envólucro sob vácuo, foram reidratadas em $1000 \mathrm{~mL}$ de água destilada a $\pm 25^{\circ} \mathrm{C}$ por 30 minutos a fim de servir como uma referência do fermento original, obtida em crescimento aeróbio com indução de acúmulo de trealose. Todas as determinações analíticas dos acompanhamentos das amostras não proliferantes foram também efetuadas com esta amostra. 


\section{RESULTADOS E DISCUSSÃO}

Foi utilizado como inóculo inicial, um lote de levedura desidratada, viva, de Saccharomyces cerevisiae, Y904, produzida e embalada a vácuo por Mauri do Brasil.

Embora as leveduras desidratadas e vivas devam ser inteiramente livres de bactérias do gênero Salmonella (Harrison, 1971), teste específico nesse sentido não foi efetuado, mas, apenas de verificação de contaminantes bacterianos e fúngicos em meio de cultura YEPD ágar a $28 \pm 1^{\circ} \mathrm{C}$ por $72 \mathrm{~h}$.

O teste efetuado em técnica de "spread plate" revelou muita uniformidade no crescimento das colônias de levedura adequadamente diluídas e nenhum crescimento bacteriano ou fúngico no período acompanhado, demonstrando a qualidade do produto.

\subsection{Fermentação}

As leveduras comerciais prensadas ou desidratadas, vivas, são obtidas através de fermentações aeróbias sequenciais até a separação final em centrífugas e filtros rotativos seguido de secagem ou prensagem antes do embalamento para armazenagem.

As leveduras são monitoradas quanto ao teor de trealose para manutenção de viabilidade celular pelo tempo pré-estabelecido de armazenamento.

Como o objetivo do presente experimento foi avaliar a capacidade de leveduras que sairam de um processo de fermentação alcoólica, portanto em 
anaerobiose, manter-se vivo sob condições aeróbias e não proliferantes, submeteu-se então a levedura desidratada a uma reativação em meio YEPD a $2 \%$ por $24 \mathrm{~h}$, seguida de uma fermentação em YEPS a $10 \%$ por outras $24 \mathrm{~h}$ a cerca de $30^{\circ} \mathrm{C}$. A concentração de açúcares adotada procurou evitar condições estressantes na fermentação e colocá-la em condições diferenciadas da fermentação de produção das leveduras comerciais.

Aproveitando a fermentação supracitada, em meio YEPS a $10 \%$, foi testada a adição de ácidos graxos, através de 2 tratamentos com 9 repetições, para avaliar sua influência na manutenção da viabilidade celular (Carvalhal et al., 1980; Alterthum \& Cruz, 1987 e Duarte et al., 1997) e monitoramento da viabilidade celular, teores de nitrogênio, carboidratos totais, trealose e glicogênio nas células coletadas após a fermentação e colocadas em estarvação em KCl 0,154M por 8 dias, sob agitação.

A fermentação, para reativação foi realizada em frasco erlenmeyer único com $1000 \mathrm{~mL}$ de meio YEPD a $2 \%$ por $24 \mathrm{~h}$, em sala de fermentação, com temperatura de $30 \pm 1^{\circ} \mathrm{C}$. Neste, foi determinado a viabilidade celular cujo dados estão mostrado na Tabela 11 e a contagem de UFC/mL realizada em meio YEPD ágar e técnica de "spread plate", na Tabela 12.

Tabela 11. Viabilidade celular em leveduras para realização da fase de fermentação.

\begin{tabular}{ccc}
\hline Amostras & \multicolumn{2}{c}{$\begin{array}{c}\text { Viabilidade celular } \\
(\%)\end{array}$} \\
\hline \multirow{2}{*}{ Inóculo inicial } & 94,40 & 92,70 \\
& 91,40 & 94,90 \\
Média & 89,70 & 91,80 \\
\hline
\end{tabular}


Tabela 12. Contagem das unidades formadoras de colônias de leveduras após fase de reativação.

\begin{tabular}{lccrc}
\hline \multicolumn{5}{c}{$\mathrm{UFC} / \mathrm{mL} \times 10^{8}$} \\
\hline 3,20 & - & 5,90 & 2,50 \\
& 5,50 & 4,74 & 4,00 & 2,66 \\
& 5,00 & 2,98 & 3,50 & 1,42 \\
& 10,20 & 3,94 & 3,60 & 3,38 \\
& 13,60 & 3,71 & 3,00 & 3,27 \\
& 13,60 & 3,13 & 4,80 & 1,25 \\
& 6,20 & 2,68 & 5,40 & 2,65 \\
Média & 5,60 & 3,05 & 3,30 & 2,47 \\
& 6,70 & 2,91 & 3,10 & 2,46 \\
\hline
\end{tabular}

O inóculo inicial da fermentação, já avaliado pela viabilidade celular e pelas unidades formadoras de colônias, foi distribuído em alíquotas de $10 \mathrm{~mL}$ da suspensão, em 54 frascos contendo $200 \mathrm{~mL}$ de meio YEPS a 10\% e agitados (90rpm) em shaker New Brunswick, modelo G53, sendo 27 frascos destinados ao tratamento T1 (sem óleo) e 27 frascos ao tratamento T2 (com óleo). O acompanhamento da fermentação foi efetuado por pesagens em 3 frascos de $\mathrm{T} 1$ e 3 frascos de $\mathrm{T} 2$, aleatoriamente e os resultados estão mostrados na Figura 2. 
Perda de massa

(g)

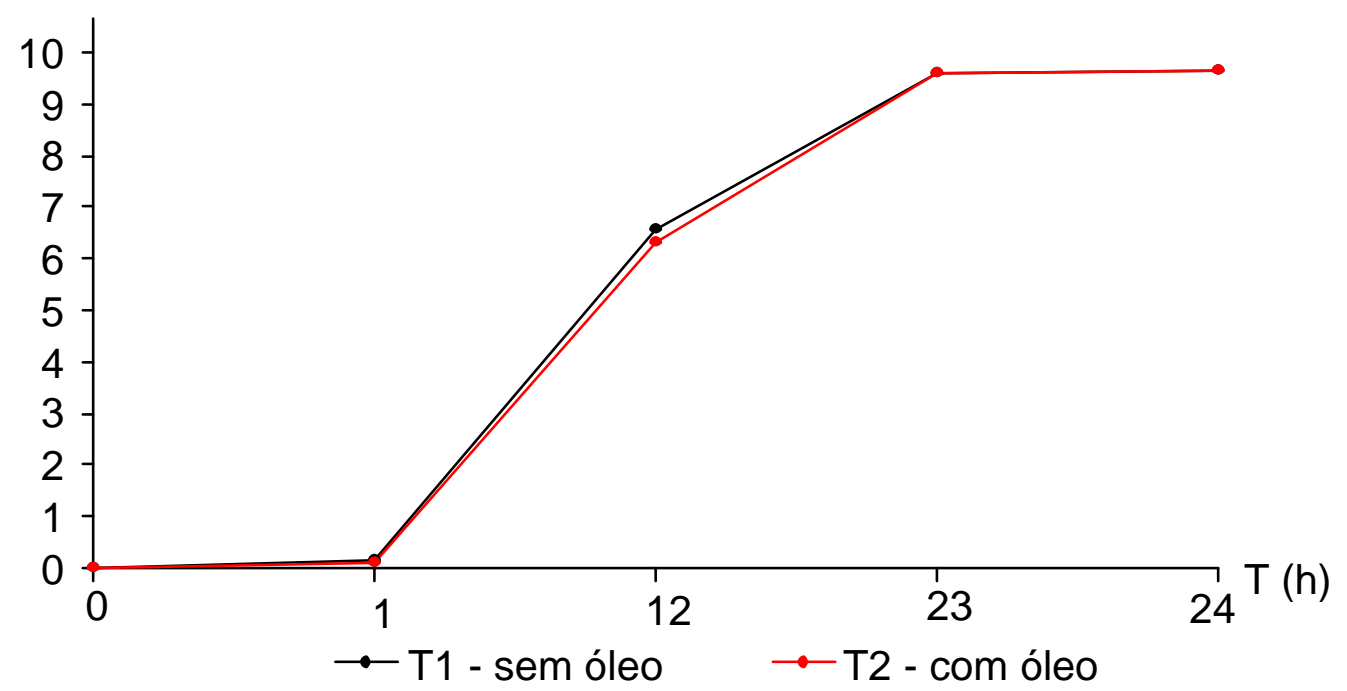

Figura 2 - Acompanhamento da fermentação pela diferença média de massa em pesagens sucessivas.

Aleatoriamente, uma em cada 3 frascos foi amostrado para determinação do teor alcoólico, sendo os resultados obtidos apresentados na Tabela 13.

Tabela 13. Teor alcoólico das amostras fermentadas em presença ou ausência de óleo de soja.

\section{Teor alcoólico}

$$
(\% \mathrm{v} / \mathrm{v})
$$

\begin{tabular}{lcccccc} 
& \multicolumn{5}{c}{ Repetições } & Média \\
\hline Tratamento 1 & 4,75 & 4,83 & 4,83 & 4,90 & 4,61 & $4,79^{\mathrm{A}}$ \\
& 4,97 & 4,68 & 4,75 & 4,83 & & \\
Tratamento 2 & 4,83 & 4,68 & 4,83 & 4,46 & 4,61 & $4,69^{\mathrm{A}}$ \\
& 4,75 & 4,68 & 4,75 & 4,61 & & \\
\hline
\end{tabular}

* Quadro da análise de variância e teste de Tukey, estão apresentados no apêndice 
A análise estatística mostra que não houve diferença entre os tratamentos quanto ao teor alcoólico no período ensaiado, porém como se trata de meio semi-sintético contendo extrato de levedura, é possível que não se espere qualquer diferença de rendimento como o encontrado por Alterthum \& Cruz (1987) em meio de melaço e a partir do segundo reciclo ou por Duarte et al. (1997) em HTM com reciclos sucessivos.

\subsection{Monitoramento das alterações fisiológicas na suspensão celular}

Os frascos que sofreram fermentação por $24 \mathrm{~h}$ no meio YEPS com e sem óleo de soja foram centrifugados, lavados e ressuspensos em $\mathrm{KCl} 0,154 \mathrm{M}$ contendo $3 \mathrm{ppm}$ de Kamoran. Estes foram agora acompanhados quanto a viabilidade celular, contagem de colônias (UFC/mL), concentração celular, nitrogênio total no meio e no microrganismo, carboidratos totais na levedura, trealose e glicogênio na levedura durante 8 dias sendo todos os fatores analisados a cada dia.

\subsubsection{Viabilidade celular}

A viabilidade celular de uma suspensão recém reidratada e um fermento cultivado em meio de fermentação por $24 \mathrm{~h}$, apresentam-se com valores diferenciados e este fato pode ser constatado também no presente experimento, mostrado na Tabela 14 e Figura 3. Notar que, embora a reidratação tenha sido feita com água a temperatura ambiente, a viabilidade celular obtida foi da ordem de $80 \%$. Já a levedura suspensa em $\mathrm{KCl} 0,154 \mathrm{M}$ após $24 \mathrm{~h}$ de cultivo mostra viabilidade que se aproxima dos $100 \%$, ou seja, uma média de $97 \%$. Ainda, pelos dados da Figura 3 observa-se que ocorre uma queda na taxa de viabilidade ao longo dos dias, acentuando-se entre $24 \mathrm{e}$ $48 \mathrm{~h}$ embora o meio, uma solução fisiológica, teoricamente não contenha

metabólicos agressivos. É então possível que a viabilidade celular esteja ligada 
à concentração de algum componente celular que esteja atingindo nível crítico e induza à perda da viabilidade. Suomalainen \& Pfaffli (1961); Crowe et al. (1984) e Alcarde \& Basso (1997), verificaram que a manutenção da viabilidade celular em levedura de panificação se mantinha elevada em função do alto teor de trealose e que este teria a função de proteger a célula contra a autólise. Lógicamente, o contrário deve provocar aumento de perda de viabilidade celular e de rapidez na ocorrência de autólise, como se verifica na Figura 3, e já havia sido correlacionado com o consumo de carboidratos, em condições aeróbias, por Ball \& Atkinson (1975) e ao contrário do encontrado por Duarte et al. (1997) quando relacionaram maior viabilidade celular à presença de óleo de soja e elevação de teor de glicogênio em consequência.

Tabela 14. Viabilidade celular, nitrogênio total, carboidratos totais, trealose e glicogênio em levedura reidratada em água.

\begin{tabular}{cccccc}
\hline Alíquota & $\begin{array}{c}\text { Viabilidade } \\
\text { Celular } \\
(\%)\end{array}$ & $\begin{array}{c}\text { Nitrogênio } \\
\text { Total } \\
(\%)\end{array}$ & $\begin{array}{c}\text { Carboidratos } \\
\text { Totais } \\
(\mathrm{g} / \mathrm{L})\end{array}$ & $\begin{array}{c}\text { Trealose } \\
(\mathrm{mg} / 100 \mathrm{mg})\end{array}$ & $\begin{array}{c}\text { Glicogênio } \\
(\mathrm{mg} / 100 \mathrm{mg})\end{array}$ \\
\hline 1 & 80,20 & 5,66 & 3,18 & 11,45 & 10,92 \\
2 & 81,50 & 5,60 & 3,04 & 10,41 & 12,31 \\
3 & 82,30 & 5,84 & 3,11 & 11,45 & 12,15 \\
4 & - & - & - & 13,14 & 13,45 \\
Média & 81,33 & 5,70 & 3,11 & 11,61 & 12,21 \\
\hline
\end{tabular}




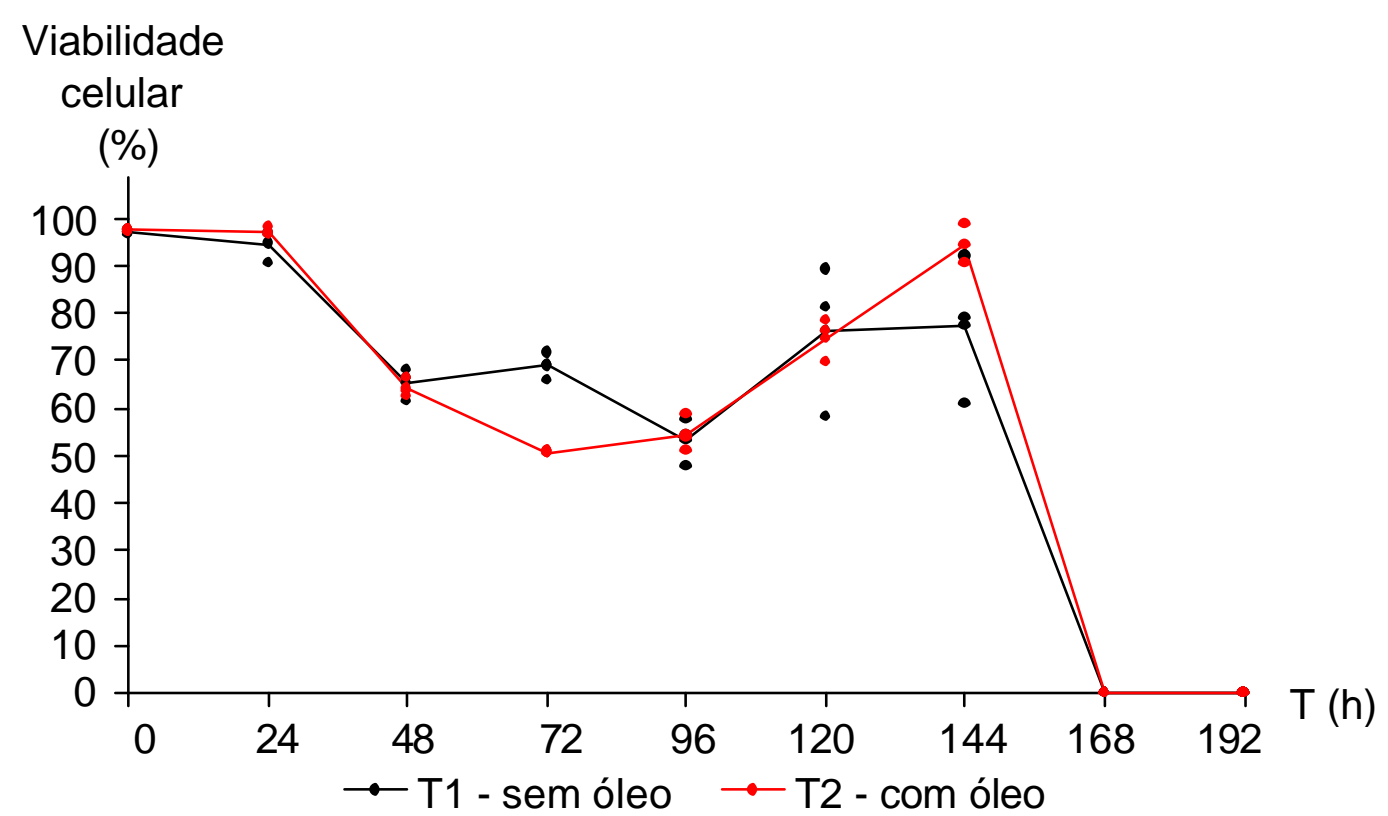

Figura 3 - Perfil da viabilidade celular de Saccharomyces cerevisiae Y904 em condições não proliferantes, sob agitação.

Acompanhando-se o perfil da viabilidade celular no experimento, verifica-se que do $4^{\circ}$ dia $(96 \mathrm{~h})$ para o $5^{\circ}$ dia (120 h) ocorreu um aumento da viabilidade celular, de cerca de $40 \%$ em relação ao $4^{\circ}$ dia (96 h), mostrando um fenômeno biológico diferenciado do observado até este momento. Ainda, só pelos dados de viabilidade celular, poder-se-ia inferir que células mortas poderiam estar autolisando-se e que pela velocidade de autólise estarem sobrando menos células, porém com maioria de viáveis, ou que a sobrevida das células vivas, está aumentada pelo fornecimento de nutrientes provenientes das células lisadas (Reed \& Peppler, 1973). Para confirmar esse raciocínio, as amostras dos dias 7 e 8 mostram que após o aumento da viabilidade, ocorre nas 24 h seguintes, um completo desaparecimento de células viáveis.

A análise estatística da variável viabilidade celular no presente experimento em delineamento fatorial, apresenta interação significativa, sendo que apenas no $4^{\circ}$ tempo ( $3^{\circ}$ dia) houve alguma dispersão de dados que podem 
ter levado a interferir na interpretação estatística. Queriamos crer que biologicamente não tenha ocorrido tal fato que contrariaria Carvalhal, et al. 1980; Alterthum \& Cruz, 1987 e Duarte et al. 1997.

Para melhor entendimento das alterações que ocorreram ao longo do período de 8 dias (192 h), não basta só o conhecimento da viabilidade celular, mas a relação entre a massa celular e a viabilidade. Observa-se pela Figura 4, que a concentração de massa celular decresce, a cada intervalo de um dia, porém que este decréscimo se acentua nos últimos 2 a 3 dias, e mais, que os resultados sofreram uma variação maior, provavelmente, com o aumento da autólise. Como a técnica de determinação da concentração da massa celular adotada foi a turbidimétrica, é possível que a partir de um certo ponto de autólise, a turvação do meio passe a interferir de tal modo que as leituras de turvação, antes interpretadas como massa celular real, passaram agora a representar massa celular fictícia, ao contrário dos fatos biológicos. Como alguns componentes celulares foram calculados em função da massa celular, os resultados de amostragens, acima de $96 \mathrm{~h}$ ( $4^{\circ} \mathrm{dia}$ ), tendem a apresentar valores irreais e com grande variação, provavelmente não fiel ao fenômeno biológico em estudo (Figura 4). 


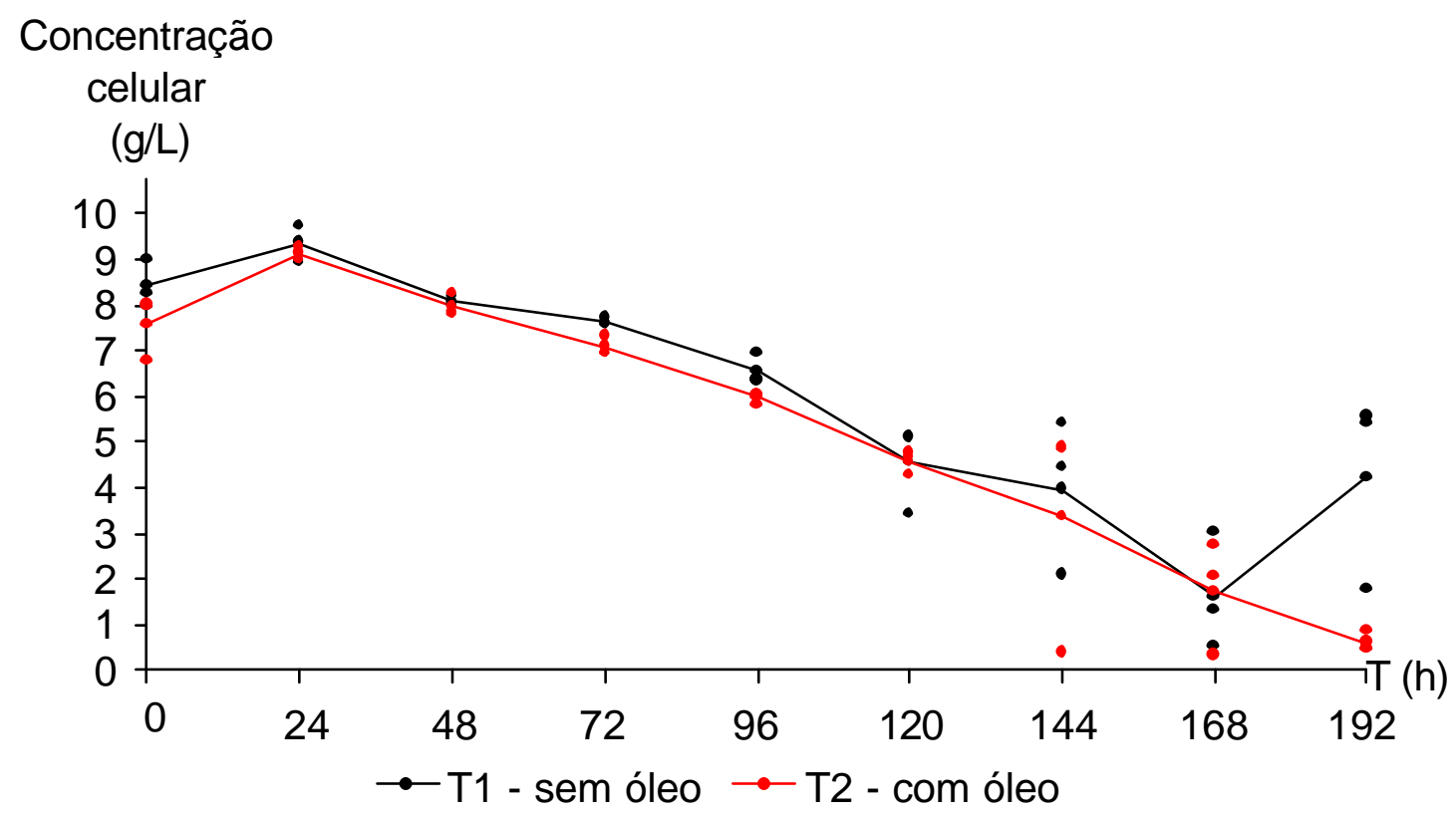

Figura 4 - Concentração celular de Saccharomyces cerevisiae em condições não proliferantes ao longo do período de 8 dias.

A análise estatística realizada com os dados até o $4^{\circ}$ dia (96 h), revelam novamente que há diferença entre os tratamentos, sendo T1 superior a T2, resta interpretar se efetivamente há diferença para melhor meio, o meio controle sem óleo ou se algum outro componente possa ter influenciado. Em realidade houve maior formação de massa celular em T1 - controle sem óleo.

\subsubsection{Nitrogênio total}

O teor de nitrogênio em leveduras é da ordem de 7,5 a $9 \%$ segundo Harrison (1971). A levedura desidratada utilizada em nossos ensaios apresentou um teor de 5,7\% (Tabela 14) quando recém hidratada e um teor mais elevado, em torno de 6 a 7\%, após ter sido submetido à fermentação (Figura 6). Talvez isso possa ser explicado em função das técnicas de produção de fermento onde a etapa final de fabricação é indução do acúmulo de 
carboidratos de reserva como a trealose e o glicogênio que possam garantir um período de armazenamento mais longo. Assim, a diferença encontrada poderia ser apenas devido aos valores relativos de nitrogênio ou proteína, em função da presença de mais ou menos carboidratos na célula.

As concentrações de nitrogênio total na célula de levedura e no meio líquido de $\mathrm{KCl}$ 0,154M, mantidas por 8 dias, para acompanhamento das variações de comportamento de S. cerevisiae Y904 estão mostrada na Figura 5.

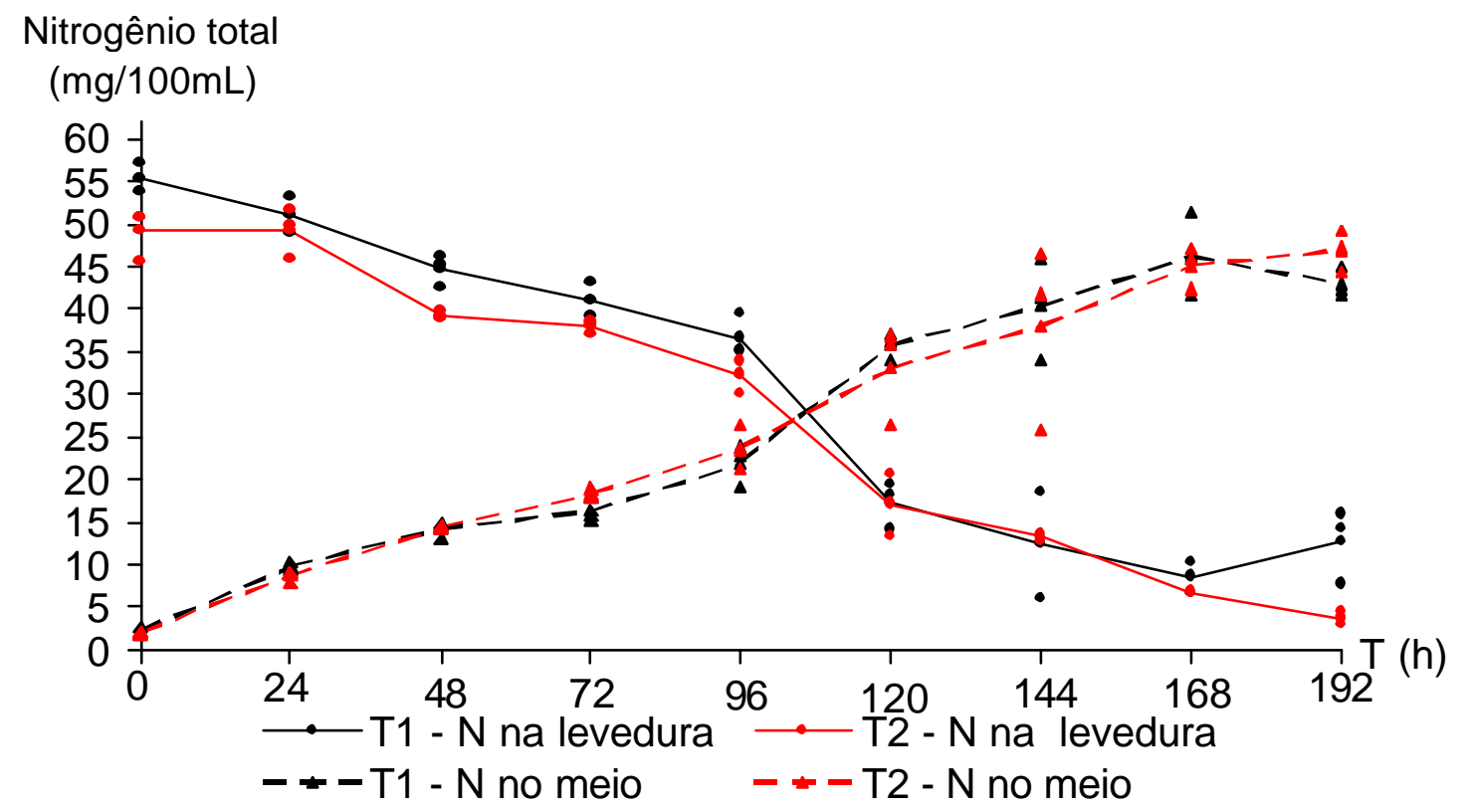

Figura 5 - Nitrogênio total na suspensão celular e no meio líquido.

$\mathrm{O}$ comportamento de $\mathrm{N}$ na célula e no meio líquido, confirma as observações já efetuadas para massa celular e para viabilidade (Tabelas 5 e 6 no apêndice).

Ao longo do tempo, há um decréscimo de $\mathrm{N}$ na suspensão de leveduras em função do decréscimo de células por autólise e este fato poderia estar sendo responsável pelo crescimento do teor de $\mathrm{N}$ no meio líquido exterior às células. Aliás, esse fenômeno já fora observado por Ferreira (1998) e Horii (1972), por ocasião do acréscimo do teor de $\mathrm{N}$ na suspensão utilizado como 
inóculo, em função do tempo de armazenamento prévio aos ensaios de fermentação.

Observa-se ainda na Figura 6, que a tendência do teor de nitrogênio na massa seca é de pequena variação percentual até $4^{\circ}$ dia (96 h), coerente com a pequena variação dos teores de carboidratos até esse mesmo período. Posteriormente, com massas celulares variando grandemente em função do método analítico, toda a variação de nitrogênio também perde significado.

$\mathrm{N}$

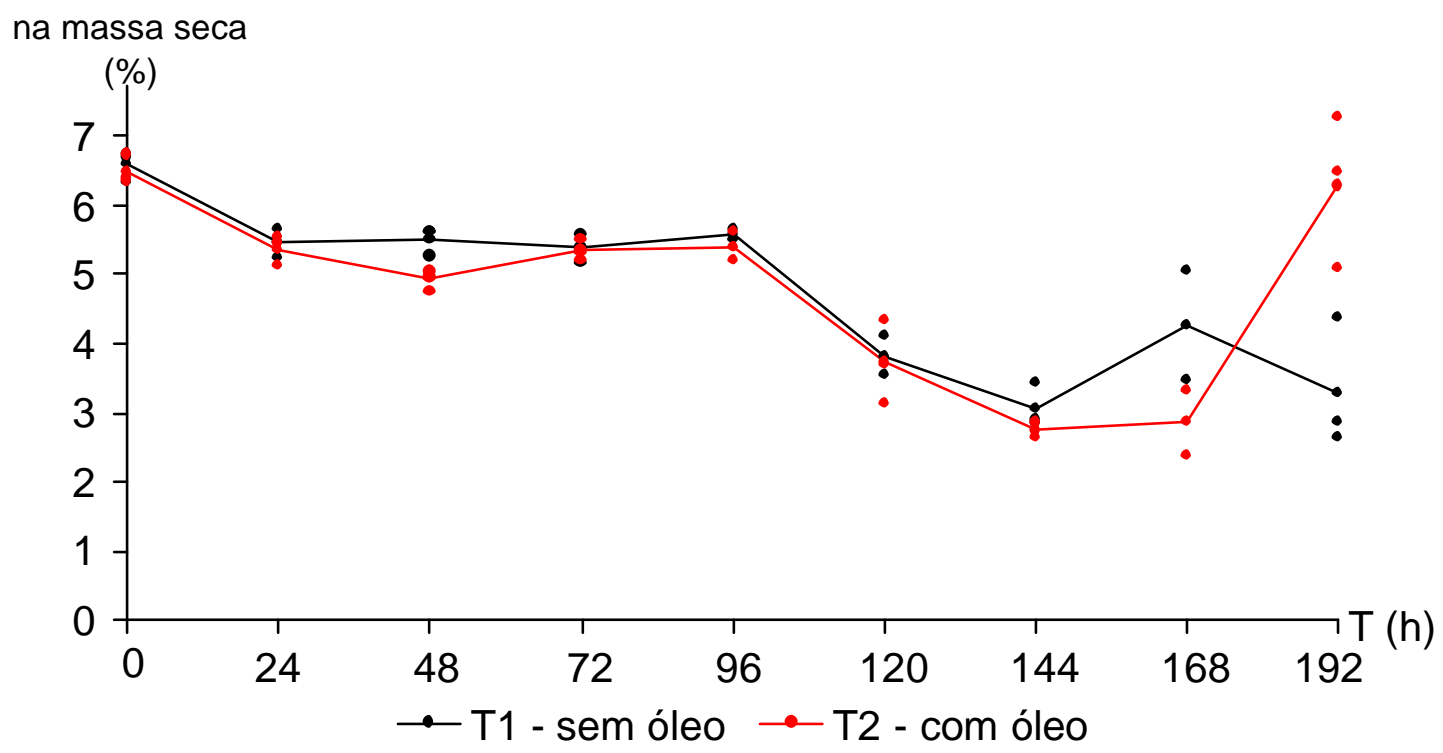

Figura 6 - Nitrogênio na massa seca de leveduras.

Por óbvio, a análise estatística dos dados segue fielmente àquela da massa celular e do carboidrato total, já que $\mathrm{N}$ é um componente da célula e para um mesmo teor, a massa de $\mathrm{N}$ acompanha a massa celular. 


\subsubsection{Carboidratos}

Mais uma vez é importante notar que a análise do fermento desidratado mostrou uma característica química voltada para a manutenção da viabilidade e da qualidade por longos períodos (Tabela 14).

Os teores de carboidratos na suspensão de células estão mostrados na Figura 7.

Os teores apresentados na Figura 7 referem-se à concentração de carboidratos totais na suspensão celular, conforme o experimento e evidencia que até $96 \mathrm{~h}$ ( $4^{\circ}$ dia) há uma relativa uniformidade e coerência; nas concentrações encontradas a partir de 120 h ( $5^{\circ}$ dia), iniciam-se variações muito grandes que podem ser acúmulo ou consumo de substrato pelas células ainda vivas e uma relativa desordem fisiológica imposta pela concentração limite de algum componente.

Carboidratos

totais

$(\mathrm{g} / \mathrm{L})$

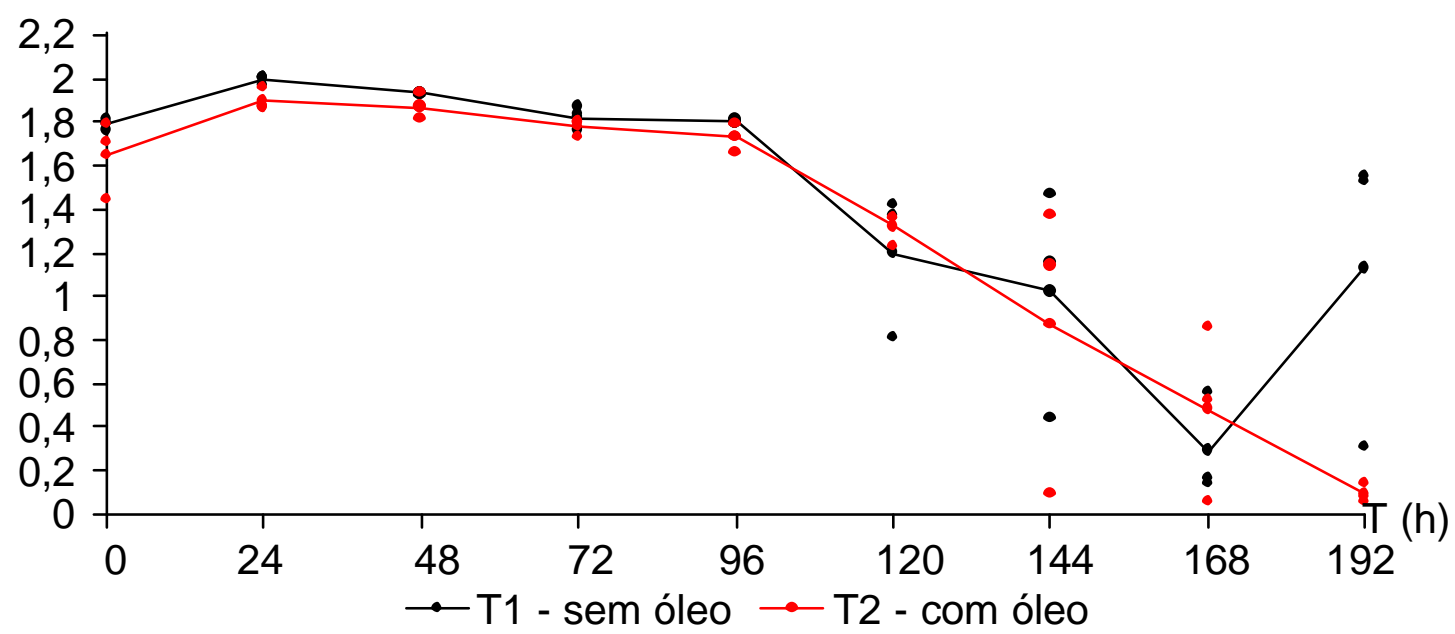

Figura 7 - Carboidratos totais obtidos na suspensão celular de leveduras, após coleta de células e lavagem. 
Pela avaliação dos teores de trealose na matéria seca (Figura 8) podese inferir que durante a fermentação o acúmulo deste é muito baixo quando comparado à levedura desidratada (Tabela 14) obtida em crescimento aeróbio, de cerca de 30 vezes e que este valor pode ser crítico à sobrevivência deste microrganismo. Por outro lado, a determinação dos valores deste carboidrato nessas concentrações tão baixas pode ser imprecisa como parece mostrar as Figura 8 e 9 . As variações são muito grandes e seria difícil aceitar acúmulo de trealose nos últimos períodos em função da disponibilidade de nutrientes produzida pela autólise de células mortas, embora Leão (1972) tenha observado que pode haver síntese de trealose, em leveduras mantidas, em condições não proliferantes, mas com glicose como fonte externa de carbono. É mais provável que nesses teores haja mesmo dificuldade de avaliação por técnica espectrofotométrica. Assim, o que poderia ser uma diferença estatística entre os tratamentos T1 e T2, certamente não pode ser levado em consideração devido aos teores muito próximos de zero, embora a análise da variância e o teste de Tukey mostrassem que os valores obtidos não representam diferenças entre os tratamentos. Foram significativos os tempos e a interação Tratamento $\times$ Tempo, todavia com um coeficiente de variação muito alto $(37,16 \%)$. É possível que a excessiva variação e dispersão dos dados analíticos da trealose tenham influenciado essa análise estatística. 


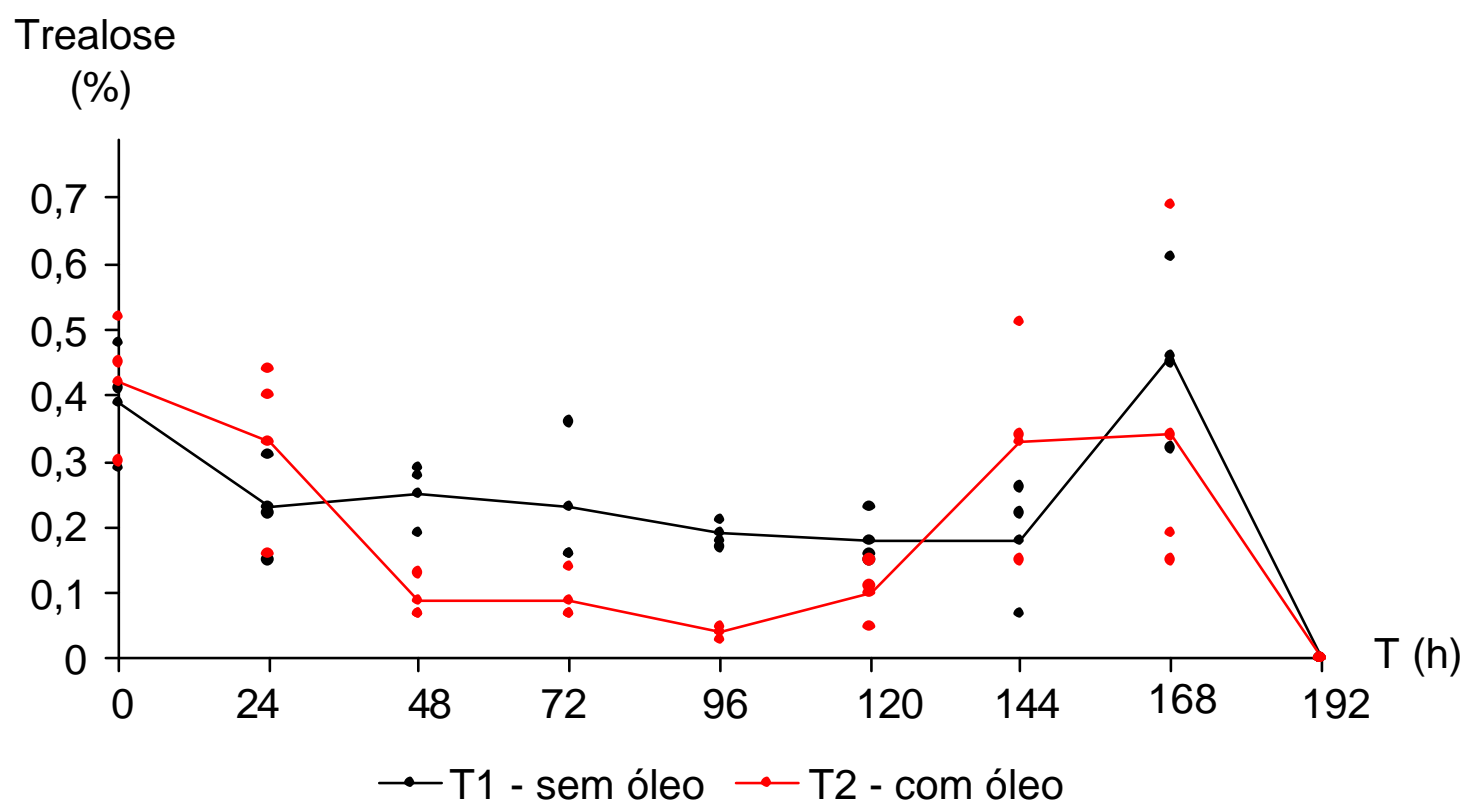

Figura 8 - Trealose em leveduras mantidas em condições não proliferantes ao longo de $192 \mathrm{~h}$. Teores percentuais em relação à matéria seca.

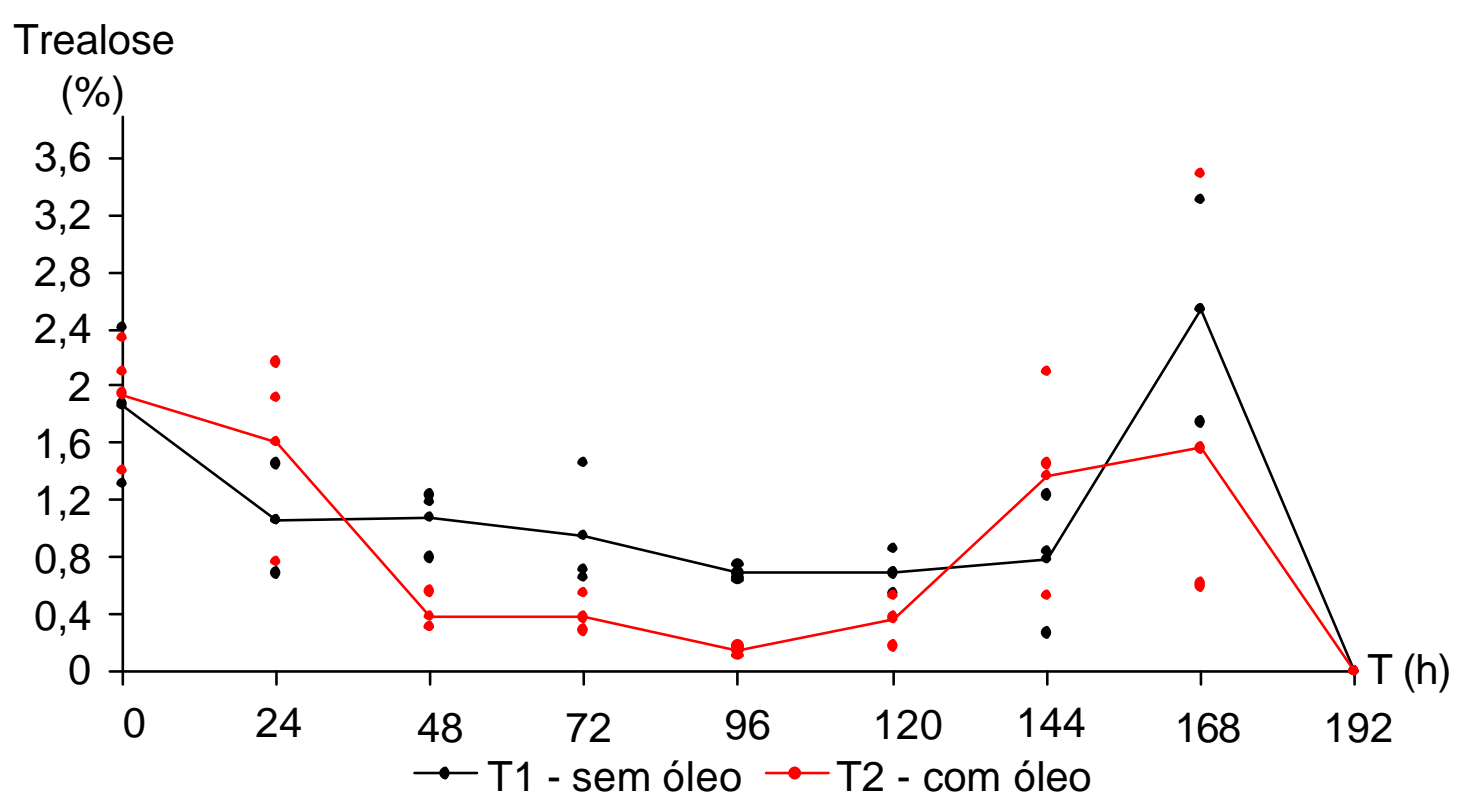

Figura 9 - Teores de trealose expressos em porcentagem dos carboidratos totais no decorrer de $192 \mathrm{~h}$, em condições não proliferantes de $S$. cerevisiae, em solução fisiológica de $\mathrm{KCl} 0,154 \mathrm{M}$. 
Os teores de trealose encontrados por Alcarde \& Basso (1997) após choque térmico, atingiram 6,33 mg/100 mg de matéria seca e Gutierrez (1990) alcançou $14,97 \mathrm{mg} / 100 \mathrm{mg}$, enquanto no presente ensaio, sem submissão a choque térmico ou variações de outras condições do meio, o acúmulo de trealose se limitou a 0,4 a 0,5 mg/100 mg de matéria seca. É possível deduzirse que em meio rico, sem condições de indução de acúmulo de carboidratos como a trealose e o glicogênio, a fermentação e o desenvolvimento celular, são limitados pela concentração de açúcar que se extingue e salvo um estímulo externo, não haverá acúmulo de carboidratos e menor será a sobrevida em condições estressantes se esta estiver ligada aos teores em questão.

Os teores de glicogênio encontrados neste experimento também confirmam que os carboidratos encontrados na levedura comercial, obtida aerobiamente, são da mesma ordem que a trealose, em média, $12 \%$ da matéria seca (Tabela 14) e que em fermentação este teor cai para cerca de $4 \%$, em média (Figura 10), um valor cerca de 10 vezes maior que o conteúdo em trealose. O teor de glicogênio ao longo do experimento sofreu pouca variação a não ser no último período avaliado que foi o $7^{\circ}$ dia (168 h). Não se observou nenhuma diferença entre os tratamentos T1 e T2 e os teores de glicogênio poderiam estar relacionados à perda de viabilidade durante jejum aeróbico, ligado ao maior consumo de reservas nessas células, conforme Ball \& Atkinson (1975), o que não se pode precisar pelos dados da presente pesquisa, a não ser os 2 últimos períodos que mostram queda no teor da reserva de glicogênio. 


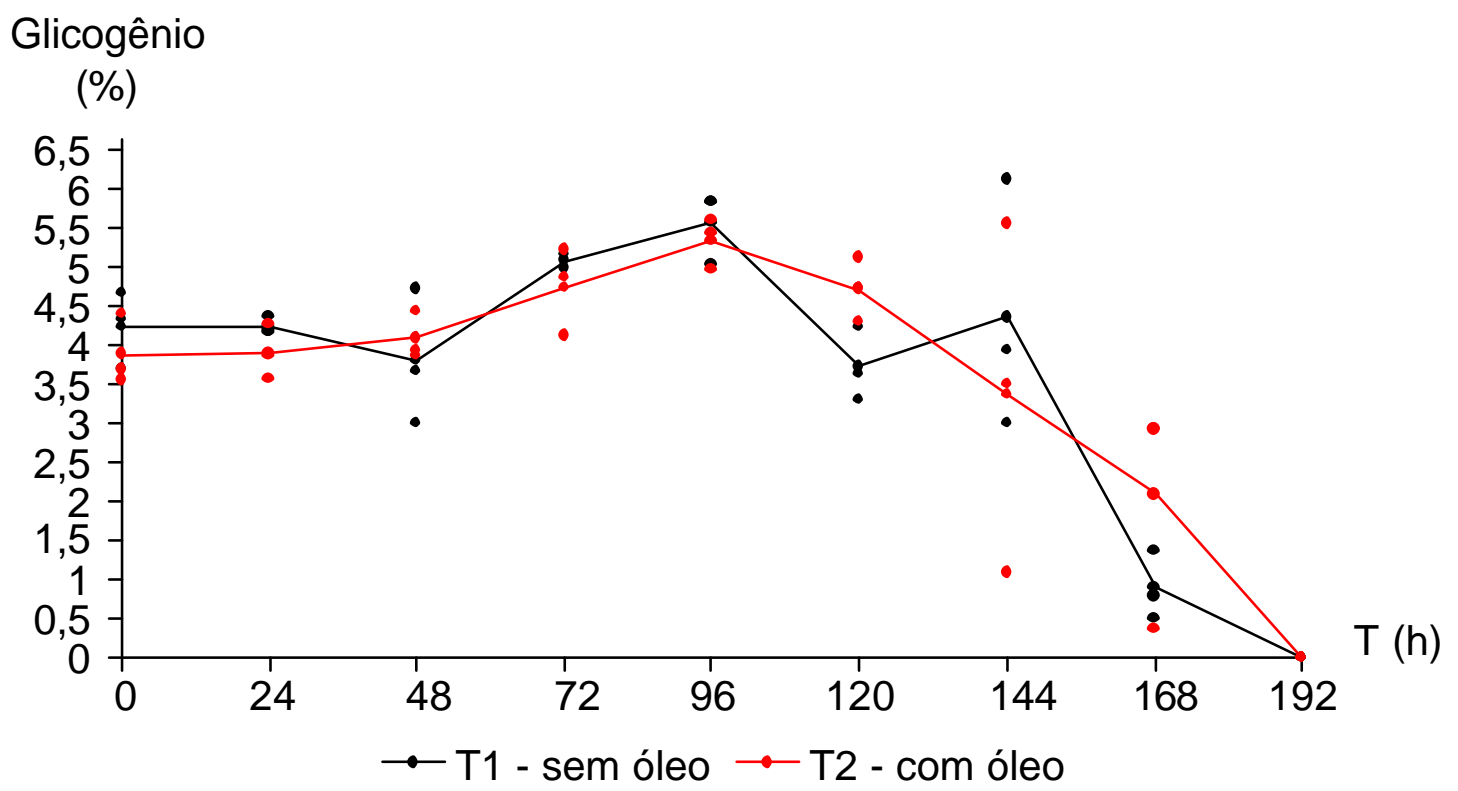

Figura 10 - Glicogênio em leveduras. Teores percentuais em relação a matéria seca de $S$. cerevisiae mantida em condições não proliferantes ao longo de $192 \mathrm{~h}$.

A análise estatística dos dados relativos aos teores de glicogênio, mais uma vez mostraram-se não significativos para tratamentos e apenas para tempos de amostragem, onde novamente os baixos valores e a dispersão dos dados analíticos podem ter sido os causadores dessa influência.

Novas pesquisas são sugeridas para melhor compreensão da variação dos carboidratos num processo não proliferante. É possível que se tenha, que provocar choque térmico ou oferta de açúcares em ausência de $\mathrm{N}$ para provocar acúmulo de trealose (Alcarde \& Basso, 1997 ; Gutierrez, 1990 ; Hottiger et al., 1987 e Leão, 1972) em fermentação e em seguida submetidas aos processos estressantes até dissimilação a níveis críticos desses carboidratos. 


\section{CONCLUSÕES}

Para as condições em que foram conduzidos os experimentos desta pesquisa, pode-se concluir o que se segue:

1. As leveduras mantidas em solução fisiológica, em condições não proliferantes, mas em agitação constante, perderam a viabilidade celular, acentuadamente, após $24 \mathrm{~h}$, e iniciaram progressiva autólise após $96-120 \mathrm{~h}$;

2. Não foi detectada qualquer diferença de comportamento na fermentação ou na resistência ao período estressante em condições não proliferantes em função do tratamento com $3 \mathrm{~g} / \mathrm{L}$ de óleo de soja;

3. Os teores de trealose e glicogênio após a fermentação foram de 0,4-0,5 mg por $100 \mathrm{mg}$ de matéria seca e $4 \mathrm{mg}$ por $100 \mathrm{mg}$ de matéria seca respectivamente, pela ausência de estímulo ao acúmulo. Estes teores muito baixos, podem ser responsáveis pela menor resistência a períodos de jejum;

4. Nas condições ensaiadas, pode-se preservar a massa de células para reutilização até um período máximo de 4 dias.

A velocidade de autólise após a perda da viabilidade celular, pode ser um fenômeno associado aos teores de carboidratos - glicogênio e trealose - e merecem ser melhor investigados visando-se informações sobre o tempo de jejum passivel de ser enfrentado para reutilização em novas fermentações. 


\section{REFERÊNCIAS BIBLIOGRÁFICAS}

ALCARDE, A.R.; BASSO, L.C. Efeito da trealose na manutenção da viabiidade de células de leveduras desidratadas por liofilização. Scientia Agricola, v.54, n.3, p.189-194, set./dez. 1997.

ALTERTHUM, F.; CRUZ, M.R.de M. Aumento do rendimento da fermentação alcoólica pela adição de óleo de soja. Revista de Microbiologia, v.18, n.1, p.52-57,jan./mar. 1987.

AMORIM, H.V.; GOMES, E. Conservação da levedura durante interrupções no processo fermentativo. Relatório Anual de Pesquisas em Fermentação Alcoólica, n. 7, p.51-54, 1987.

AMORIM, H.V.; GOMES, E. Conservação de levedura durante interrupções no processo fermentativo. Relatório Anual de Pesquisas em Fermentação Alcoólica, n. 8, p.48-59, 1988.

BACILA, M. Curso de fisiologia de microrganismo. Curitiba: UFPr,Instituto de Bioquímica, 1960, 209p.

BALL, W.J.; ATKINSON, D.E. Adenylate energy charge in Saccharomyces cerevisiae during starvation. Journal of Bacteriology, v.121, n.3, p.975982, Mar. 1975. 
BENDOVÁ, O.; RICHTER, V.; JANDEROVÁ, B.; HÄUSLER, J. Identification of industrial yeast strains of Saccharomyces cerevisiae by fatty acid profiles. Applied Microbiology and Biotechnology, v.35, n.6, p.810-812, Sep.1991.

BERKE, H.L.; ROTHSTEIN, A. The metabolism of storage carbohydrates in yeast studied with glucose $-1-C^{14}$ and Dinitrophenol. Archives of Biochemistry and Biophysics, v.72, p.380-395, 1957.

BLOOMFIELD, D.K.; BLOCH, K. The formation of $\Delta^{9}$ - Unsaturated fatty acids. Journal of Biological Chemistry, v.235, n1-3, p.337-345, 1960.

BRIN, M. Tranketolase: clinical aspects. Method in Enzymology, v.9, p.506$514,1966$.

BROWN, C.M.; ROSE, A.H. Fatty-acid composition of Candida utilis as affected by growth temperature and dissolved-oxigen tension. Journal of Bacteriology, v.99, n.2, p.371-378, Aug. 1969.

CABALLERO CÓRDOBA, G.M.; PACHECO, M.T.B.; SGARBIERI, V.C. Composição química da biomassa de levedura integral (Saccharomyces $s p$.$) e determinação do valor nutritivo da proteína em células integras ou$ rompidas mecanicamente. Ciência e Tecnologia de Alimentos, v.17, n.2, p.102-106, maio/ago. 1997.

CABIB, E.; LELOIR,L.F. The biosynthesis of trehalose phosphate. Journal of Biological Chemistry, v.231, p.259-275, 1958. 
CARVALHAL, M.L.C.; CASTELLANI, B.R.; ALTERTHUM, F. Efeito de antibióticos poliênicos sobre Saccharomyces cerevisiae contendo diferentes esteróis e ácidos graxos insaturados incorporados à membrana citoplasmática. Revista de Microbiologia, v.11, n.3, p.71-75, jul./set. 1980.

CARVALHO, L.C.C. Cenário sucroalcooleiro. STAB. Açúcar, Álcool e Subprodutos, v.18, n.6, p.8-9, jul./ago. 2000.

CHEN, S.L. Carbohydrate assimilation in actively growing yeast, Saccharomyces cerevisiae Biochimica et Biophysica Acta, v.32, p.470479, 1959a.

CHEN, S.L. Carbohydrate assimilation in actively growing yeast, Saccharomyces cerevisiae Biochimica et Biophysica Acta, v.32, p.480484, 1959b.

CROWE, J.H.; CROWE, L.M.; CHAPMAN, D. Preservation of Membranes in anhydrobiotic organisms: The role of trehalose. Science, v.223, n.4637, p.701-703, Feb. 1984.

DESMONTS, R. Utilização do levedo na alimentação da criança. Pediatria Prática, v.39, n.7, p.7-18, jul. 1968.

DUARTE, M.C.T.; SERZEDELLO, A.; PONEZI, A.N.; SERRA, G.E.; OLIVEIRA, M.C.de.F.L.de.O. Effect of soy oil on the carbohydrate reserves of Saccharomyces uvarum IZ 1904 in fermentative conditions. Revista de Microbiologia, v.28, n.1, p.17-22, jan./fev. 1997. 
FERREIRA, L.V. Fermentação de trealose e glicogênio endógenos em Saccharomyces cerevisiae. Piracicaba, 1998. 125p. Dissertação (Mestrado) - Escola Superior de Agricultura "Luiz de Queiroz", Universidade de São Paulo.

FERREIRA, L.V.; AMORIM, H.V.; BASSO, L.C. Fermentação de trealose e glicogênio endógenos em Saccharomyces cerevisiae, Ciência e Tecnologia de Alimentos, v.19, n.1, p.29-32, jan./abr. 1999.

FIALHO, E.T.; GOMES, P.C.; ALBINO, L.F.T.; COSTA, V. Determinação dos valores de composição química e de digestibilidade de alguns ingredientes nacionais para suínos. Revista da Sociedade Brasileira de Zootecnia, v.12, n.2, p.337-356, 1983.

FONSECA, H.; GUTIERREZ, L.E. Composição em ácidos graxos de óleos vegetais e gorduras animais. Anais da Escola Superior de Agricultura “Luiz de Queiroz”, v.31, p.485-490, 1974.

GHIRALDINI, J.A; ROSSELL, C.E.V. Caracterização e qualidade de levedura desidratada para a alimentação animal. In: SIMPÓSIO SOBRE TECNOLOGIA DA PRODUÇÃO E UTILIZAÇÃO DA LEVEDURA DESIDRATADA NA ALIMENTAÇÃO ANIMAL, Campinas, 1997. Anais. Campinas: Colégio Brasileiro de Nutrição Animal, 1997. p.27-48.

GOMES, E. Efeito do tratamento ácido da levedura Saccharomyces cerevisiae na fermentação alcoólica. Piracicaba, 1988. 206p. Dissertação (Mestrado) - Escola Superior de Agricultura "Luiz de Queiroz", Universidade de São Paulo. 
GUTIERREZ, L.E. Acúmulo de trealose em linhagens de Saccharomyces durante fermentação alcoólica. Anais da Escola Superior de Agricultura “Luiz de Queiroz”, v.47, n.2, p.597-608, 1990.

GUTIERREZ, L.E. Composição em ácidos graxos e viabilidade celular em Saccharomyces cerevisiae. STAB. Açúcar, Álcool e Subprodutos, v.9, n.6, p.31-34, jul./ago. 1991.

GUTIERREZ, L.E. Bioquímica de leveduras. Piracicaba: ESALQ,Dept. Ciência e Tecnologia Agroindustrial, 1997. 270p.

GUTIERREZ, L.E.; SILVA, R.C.M.da. Fatty acid composition of cane molasses and yeasts. Scientia Agricola. v.50, n.3, p.473-477, out./dez. 1993.

GUTIERREZ, L.E.; ANNICCHINO, A.V.K.O.; LUCATTI, L. Capacidade fermentativa de Saccharomyces cerevisiae enriquecida com ácidos graxos. Anais da Escola Superior de Agricultura "Luiz de Queiroz", v.47, n.2, p.575-595, 1990.

HALÁSZ, A.; LÁSZTITY, R. Use of yeast biomass in food production. Boca Raton: CRC Press, 1991. 312p.

HALÁSZ, A.; BARÁTH. Á.; MÁTRAI, B. Yeast as a human protein source. Acta Alimentaria, v.17, n.4, p.374-375, Dec. 1988.

HARRISON, J.S. Yeast production. HOCKENHULL, D.J.D. Progress in industrial microbiology. London, Colchester and Beccles, 1971. cap.4, p.129-178: Yeast production. 
HAYASHIDA, S.; FENG, D.D.; HONGO, M. Function of the high concentration alcohol-producing factor. Agricultural and Biological Chemistry, v.38, n.10, p.2001-2006, 1974.

HORII, J. Contribuição ao estudo do metabolismo da glicose em Saccharomyces carlsbergensis Hansen. Piracicaba, 1972. 86p. Tese (Doutorado) - Escola Superior de Agricultura "Luiz de Queiroz", Universidade de São Paulo.

HOTTIGER, T.; SCHMUTZ, P.; WIEMKEN, A. Heat-induced accumulation and futile cycling of trehalose in Saccharomyces cerevisiae. Journal of Bacteriology, v.169, n.12, p.5518-5522, Dec. 1987.

HUNTER, K.; ROSE, A.H. Yeast lipids and membranes. In: ROSE, A.H.; HARRISON, J.S. The yeasts. London: Academic Press, 1971. cap.6, 211270.

KELLER, F.; SCHELLENBERG, M.; WIEMKEN, A. Localization of trehalase in vacuoles and of trehalose in the cytosol of yeast (Saccharomyces cerevisiae). Archives of Microbiology, v.131, n. 4, p.298-301, June 1982.

KOSHIMIZU, L.H.; CRUZ, M.R.de.M.; GOMEZ, E.I.V.; NETTO, C.L.B.; GONÇALVES, A.C.R.; BORZANI, W. Avaliação da concentração de leveduras suspensas em um meio aquoso pela medida do volume ocupado pelas células. Saccharum STAB, v.4, n.18, p.14-16, jan. 1982. 
LAHR FILHO,D.; GHIRALDINI, J.A.; ROSSELL, C.E.V. Estudos de otimização da recuperação de biomassa de levedura em destilarias. In: SGARBIERI, V.C.; DRAETTA, I.S. (Coord.) Produção de biomassa de levedura: Utilização em alimentação humana e animal. Campinas: ITAL, 1996, p.5967.

LALUCE, C. Leveduras termotolerantes. STAB. Açúcar, Álcool e Subprodutos, v.9, n.6, p.40-43, jul./ago. 1991.

LEÃO, M.H.M.R. Metabolismo de trealose e glicogênio em levedura de cervejaria. Rio de Janeiro, 1972. 58p. Dissertação (M.S.) - Universidade Federal do Rio de Janeiro.

LEÃO, M.H.M.R.; PANEK, A.D.; CARVALHO, V.L.A.C. Glycogen accumulation during growth of Saccharomyces cerevisiae: catabolite repression effects. I.R.C.S. Medical Science, v.12, p.411-412, 1984.

LILLIE, S.H.; PRINGLE, J.R. Reserve carbohydrate metabolism in Saccharomyces cerevisiae. Responses to nutrient limitation. Journal of Bacteriology, v.143, n.3, 1384-1394, Sept. 1980.

LIMA, G.J.M.M.de. Uso da levedura seca (Saccharomyces cerevisiae) de destilarias de álcool de cana de açúcar na alimentação de matrizes suínas em gestação e lactação. Piracicaba, 1983. 139p. Dissertação (Mestrado) Escola Superior de Agricultura "Luiz de Queiroz", Universidade de São Paulo.

MALLETTE, M.F. Evaluation of growth by physical and chemical means. Methods in Microbiology, v.1, p.521-566, 1969. 
MANNERS, D.J. The structure and biosynthesis of storage carbohydrates in yeast. In: ROSE, A.H.; HARRISON, J.S. The yeasts. London: Academic Press, 1971. cap.10, 419-439.

MARQUES, T.A. O uso de fermento reciclado com teor reduzido em metabólitos e seu efeito na fermentação alcoólica. Campinas, 1997. 105p. Tese (Doutorado) - Universidade Estadual de Campinas.

MARTÍN, M.C.; DÍAZ, L.A.; MANZANAL, M.B.; HARDISSON, C. Role of trehalose in the spores of Streptomyces. F.E.M.S. Microbiology Letters, v.35, p.49-54, 1986.

MATIAZI, H.J. Efeito de agentes estressantes sobre o teor de trealose em Saccharomyces cerevisiae. Piracicaba, 1995. 70p. Dissertação (Mestrado) - Escola Superior de Agricultura "Luiz de Queiroz", Universidade de São Paulo.

MIYADA, V.S. Uso da levedura seca (Saccharomyces cerevisiae) de distilarias de álcool de cana de açúcar na alimentação de suínos em crescimento e acabamento. Piracicaba, 1978. 106p. Dissertação (Mestrado) - Escola Superior de Agricultura "Luiz de Queiroz", Universidade de São Paulo.

MOREIRA, J.R.de.A. Uso da levedura seca (Saccharomyces cerevisiae) de destilarias de álcool de cana de açúcar em rações isocalóricas para suínos em crescimento e acabamento. Piracicaba, 1984. 107p. Dissertação (Mestrado) - Escola Superior de Agricultura "Luiz de Queiroz", Universidade de São Paulo. 
NOGUEIRA, I.F.; OLIVA NETO, P.de. Efeito dos parâmetros físicos no metabolismo de carboidratos de reserva de Saccharomyces cerevisiae. In: CONGRESSO BRASILEIRO DE CIÊNCIA E TECNOLOGIA DE ALIMENTOS, 17., Fortaleza, 2000. Alimentos para o terceiro milênio. resumos. Fortaleza: Expressão Gráfica Digital, 2000. 1v.

PEPPLER, H.J. Food yeasts. In: ROSE, A.H.; HARRISON, J.S. The yeasts. London: Academic Press, 1970. cap.8, p.421-463.

PIERCE, J.S. Measurement of yeast viability. Journal of the Institute of Brewing, v.76, p.442-443, 1970.

QUAIN, D.E. Studies on yeast physiology-impact on fermentation performance and product quality. Journal of the Institute of Brewing, v.95, n.5, p.315323. Sept./Oct. 1988.

QUAIN, D.E.; THURSTON, P.A.; TUBB, R.S. The structural and storage carbohydrates of Saccharomyces cerevisiae: Change during fermentation of wort and role for glycogen catabolism in lipid biosythesis. Journal of The Institute of Brewing, v.87, n.2, p.108-111, Mar./Apr. 1981.

QUASTEL, J.H. Meetings. Science, v.158, p.146-161, Oct./Dec. 1967.

REED, G.; PEPPLER, H.J. Yeast technology. Westport: The Avi Publishing Company, 1973. 378p.

RESENDE, M.A.de; ALTERTHUM, F. Effect of temperature on the lipid composition of anaerobically grown Saccharomyces cerevisiae. Revista Latino Americana de Microbiologia, v.28, n.4, p.345-349, oct/dic. 1986. 
RIBEIRO, C.A.F. Potencialidades de diferentes linhagens de levedura da espécie Saccharomyces cerevisiae na tecnologia de aguardente de cana. Piracicaba, 1997. 107p. Dissertação (Mestrado) - Escola Superior de Agricultura "Luiz de Queiroz", Universidade de São Paulo.

RIBEIRO, F.J.; LOPES, J.J.C.; FERRARI, S.E. Complementação de nitrogênio de forma contínua no processo de fermentação alcoólica. Brasil Açucareiro, v.105, n.1, p.26-30, 1987.

SILVA, D.J. Análise de alimentos. 2.ed. Viçosa: Universidade Federal de Viçosa, 1990. 165p.

STUPIELLO, J.P.; HORII, J. Condução da fermentação alcoólica. Saccharum STAB, v.4, n.17, p.43-46, nov. 1981.

SUOMALAINEN, H.; PFAFFLI, S. Changes in the carbohydrate reserves of baker's yeast during growth and on standing. Journal of the Institute of Brewing, v.67, p.249-254, 1961.

THOMAS, D.S.; ROSE, A.H. Inhibitory effect of ethanol on growth and solute accumulation by Saccharomyces cerevisiae as affected by plasmamembrane lipid composition. Archives of Microbiology, v.122, n. 1, p.4955, July 1979.

TREVELEIN, J.M. Regulation of trehalose mobilization in fungi. Microbiological Reviews, v.48, n.1, p.42-59, Mar. 1984.

TREVELYAN, W.E.; HARRISON, J.S. Studies on yeast metabolism: The trehalose content of baker's yeast during anaerobic fermentation. Biochemical Journal, v.62, n.2, p.177-183, 1956a. 
TREVELYAN, W.E.; HARRISON, J.S. Studies on yeast metabolism: Yeast carbohydrate fractions. Separation from nucleic acid, analysis, and behavior during anaerobic fermentation. Biochemical Journal, v.63, p.23-33, 1956b.

TREVELYAN, W.E.; GAMMON, J.N.; WIGGINS, E.H.; HARRISON, J.S. Studies on yeast metabolism: Synthesis of cell carbohydrates during glucose fermentation and its inhibition by azide. Biochemical Journal, v.50, p.303-310, 1952.

VASCONCELOS, J.N.de. Influência da complementação de nutrientes nitrogenados e fosfatados sobre o processo de fermentação alcoólica industrial. Brasil Açucareiro, v.105, n.4/6, p.41-48, 1987.

WHITE, J. Yeast technology. London: Chapmam and Hall, 1954. 432p.

WIEMKEN, A. Thehalose in yeast, stress protectant rather than reserve carbohydrate. Antonie Van Leeuwenhoek, v.58, n.3, p209-217, Oct. 1990.

WILSON, K.; McLEOD. B.J. The influence of conditions of growth on the endogenous metabolism of Saccharomyces cerevisiae: effect on protein, carbohydrate, sterol and fatty acid contend and on viability. Antonie Van Leeuwenhoek, v.42, n.4, p397-410, 1976. 


\section{APÊNDICES}


Tabela 1. Caracterização do final de fermentação através de pesagem.

\begin{tabular}{ccccccc}
\hline \multirow{2}{*}{$\begin{array}{c}\text { Tempos } \\
\text { (h) }\end{array}$} & & \multicolumn{5}{c}{$\begin{array}{c}\text { Diferença de massa } \\
(\mathrm{g})\end{array}$} \\
& 1 & $\mathrm{~T} 1$ & & & $\mathrm{~T} 2$ & \\
& & 2 & 3 & 1 & 2 & 3 \\
\hline 0 & 384,81 & 379,25 & 386,84 & 347,58 & 379,23 & 368,00 \\
1 & 384,68 & 379,13 & 386,71 & 347,46 & 379,11 & 367,87 \\
12 & 378,25 & 372,69 & 380,26 & 341,22 & 372,83 & 361,83 \\
23 & 375,21 & 369,63 & 377,19 & 338,01 & 369,50 & 358,43 \\
24 & 375,19 & 369,61 & 377,16 & 337,98 & 369,48 & 358,41 \\
\hline
\end{tabular}


Tabela 2. Contagem de unidades formadoras de colônias, sob condições não proliferantes.

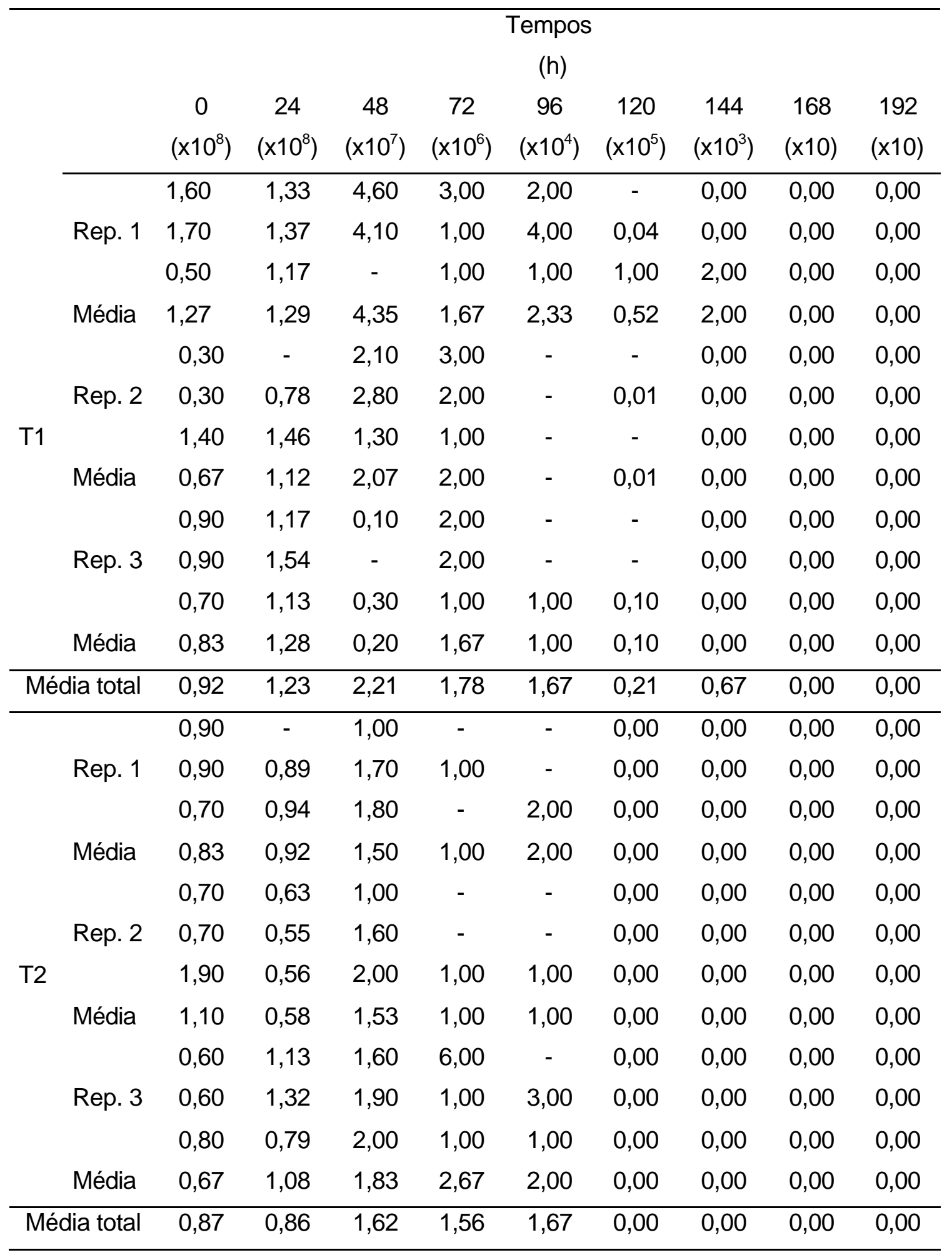


Tabela 3. Viabilidade celular de Saccharomyces cerevisiae Y904 em condições não proliferantes, sob agitação.

\begin{tabular}{ccccccccc}
\hline \multicolumn{2}{c}{$\begin{array}{c}\text { Tratamentos } \\
\text { Tempo }\end{array}$} & \multicolumn{3}{c}{ Repetição } & & \multicolumn{4}{c}{ Média } & \multicolumn{3}{c}{ Repetição } & Média \\
(h) & 1 & 2 & 3 & $(\%)$ & 1 & 2 & 3 & $(\%)$ \\
\hline 0 & 97,10 & 97,60 & 96,60 & 97,10 & 97,20 & 97,70 & 97,70 & 97,53 \\
24 & 90,40 & 97,10 & 96,40 & 94,63 & 96,70 & 98,20 & 96,70 & 97,20 \\
48 & 68,20 & 61,50 & 66,40 & 65,37 & 62,50 & 63,60 & 66,60 & 64,23 \\
72 & 71,70 & 69,00 & 66,00 & 68,90 & 50,70 & 50,50 & 51,00 & 50,73 \\
96 & 57,50 & 54,40 & 47,80 & 53,23 & 50,80 & 53,80 & 58,60 & 54,40 \\
120 & 81,10 & 89,20 & 58,20 & 76,17 & 78,60 & 69,60 & 76,20 & 74,80 \\
144 & 91,90 & 61,00 & 78,90 & 77,27 & - & 90,40 & 98,60 & 94,50 \\
168 & 0,00 & 0,00 & 0,00 & 0,00 & 0,00 & 0,00 & 0,00 & 0,00 \\
192 & 0,00 & 0,00 & 0,00 & 0,00 & 0,00 & 0,00 & 0,00 & 0,00 \\
\hline
\end{tabular}


Tabela 4. Concentração celular de S. cerevisiae em condições não proliferantes ao longo do período de 8 dias.

\begin{tabular}{|c|c|c|c|c|c|c|c|c|}
\hline \multirow{2}{*}{\multicolumn{2}{|c|}{$\begin{array}{l}\text { Tratamento } \\
\text { Tempo }\end{array}$}} & \multicolumn{2}{|c|}{$\mathrm{T} 1$} & & \multicolumn{4}{|c|}{ T2 } \\
\hline & & \multicolumn{2}{|c|}{$\begin{array}{l}\text { Repetição } \\
\qquad(\mathrm{g} / \mathrm{L})\end{array}$} & \multirow[t]{2}{*}{ Média } & \multicolumn{3}{|c|}{$\begin{array}{l}\text { Repetição } \\
\text { (g/L) }\end{array}$} & \multirow[t]{2}{*}{ Média } \\
\hline (h) & 1 & 2 & 3 & & 1 & 2 & 3 & \\
\hline 0 & 9,02 & 7,96 & 8,25 & 8,41 & 8,02 & 6,79 & 7,97 & 7,59 \\
\hline 24 & 8,94 & 9,42 & 9,75 & 9,37 & 8,99 & 9,15 & 9,30 & 9,15 \\
\hline 48 & 8,01 & 8,09 & 8,22 & 8,11 & 7,88 & 7,79 & 8,28 & 7,98 \\
\hline 72 & 7,61 & 7,57 & 7,72 & 7,63 & 6,98 & 6,98 & 7,32 & 7,09 \\
\hline 96 & 6,98 & 6,36 & 6,36 & 6,57 & 6,04 & 5,82 & 6,05 & 5,97 \\
\hline 120 & 5,14 & 3,44 & 5,11 & 4,56 & 4,28 & 4,77 & 4,67 & 4,57 \\
\hline 144 & 4,45 & 5,41 & 2,09 & 3,98 & 0,39 & 4,83 & 4,89 & 3,37 \\
\hline 168 & 1,32 & 3,01 & 0,54 & 1,62 & 2,75 & 0,33 & 2,07 & 1,72 \\
\hline 192 & 1,77 & 5,57 & 5,41 & 4,25 & 0,48 & 0,49 & 0,88 & 0,62 \\
\hline
\end{tabular}

A determinação foi efetuada por técnica turbidimétrica 
Tabela 5. Nitrogênio total nas células de leveduras mantidas em suspensão.

\begin{tabular}{|c|c|c|c|c|c|c|c|c|}
\hline \multirow{2}{*}{\multicolumn{2}{|c|}{$\begin{array}{l}\text { Tratamento } \\
\text { Tempo }\end{array}$}} & \multicolumn{2}{|c|}{ T1 } & & \multicolumn{4}{|c|}{ T2 } \\
\hline & & \multicolumn{2}{|c|}{$\begin{array}{c}\text { Repetição } \\
\text { (mg/100 mL) }\end{array}$} & \multirow[t]{2}{*}{ Média } & \multicolumn{3}{|c|}{$\begin{array}{c}\text { Repetição } \\
\text { (mg/100 mL) }\end{array}$} & \multirow[t]{2}{*}{ Média } \\
\hline (h) & 1 & 2 & 3 & & 1 & 2 & 3 & \\
\hline 0 & 57,14 & 53,72 & 55,21 & 55,36 & 50,89 & 45,68 & 50,89 & 49,15 \\
\hline 24 & 48,96 & 53,27 & 51,04 & 51,09 & 45,98 & 49,85 & 51,64 & 49,16 \\
\hline 48 & 45,09 & 42,56 & 46,28 & 44,64 & 39,73 & 38,84 & 39,28 & 39,28 \\
\hline 72 & 41,07 & 39,14 & 43,15 & 41,12 & 37,05 & 38,54 & 38,24 & 37,94 \\
\hline 96 & 39,58 & 35,12 & 35,12 & 36,61 & 33,93 & 30,21 & 32,59 & 32,24 \\
\hline 120 & 19,49 & 14,14 & 18,15 & 17,26 & 13,39 & 20,68 & 17,26 & 17,11 \\
\hline 144 & 12,65 & 18,60 & 6,10 & 12,45 & - & 13,69 & 12,80 & 13,25 \\
\hline 168 & 6,70 & 10,42 & - & 8,56 & 6,55 & - & 6,85 & 6,70 \\
\hline 192 & 7,74 & 15,92 & 14,29 & 12,65 & 3,12 & 3,57 & 4,46 & 3,72 \\
\hline
\end{tabular}

Tabela 6. Nitrogênio total na fase líquida da suspensão.

\begin{tabular}{ccccccccc}
\hline $\begin{array}{c}\text { Tratamento } \\
\text { Tempo }\end{array}$ & \multicolumn{3}{c}{$\begin{array}{c}\text { Repetição } \\
\text { (mg/100 mL) }\end{array}$} & Média & \multicolumn{4}{c}{$\begin{array}{c}\text { T2 } \\
\text { Repetição }\end{array}$} \\
(h) & 1 & 2 & 3 & & 1 & 2 & 3 & Média \\
\hline 0 & 2,60 & 2,08 & 1,79 & 2,16 & 2,23 & 1,79 & 2,16 & 2,06 \\
24 & 10,34 & 9,82 & 9,30 & 9,82 & 9,15 & 9,08 & 7,96 & 8,73 \\
48 & 14,96 & 14,66 & 13,09 & 14,24 & 14,51 & 14,29 & 14,51 & 14,44 \\
72 & 15,18 & 18,01 & 15,70 & 16,30 & 18,08 & 18,97 & 17,86 & 18,30 \\
96 & 19,12 & 23,88 & 22,77 & 21,92 & 21,35 & 23,36 & 26,34 & 23,68 \\
120 & 34,00 & 37,05 & 36,31 & 35,79 & 36,90 & 26,49 & 35,86 & 33,08 \\
144 & 41,44 & 34,00 & 45,83 & 40,42 & 41,81 & 25,74 & 46,58 & 38,04 \\
168 & 45,98 & 41,59 & 51,26 & 46,28 & 42,41 & 45,98 & 47,02 & 45,14 \\
192 & 45,01 & 41,52 & 42,34 & 42,96 & 44,42 & 47,32 & 49,25 & 47,00 \\
\hline
\end{tabular}


Tabela 7. Nitrogênio na massa seca de leveduras.

\begin{tabular}{ccccccccc}
\hline $\begin{array}{c}\text { Tratamento } \\
\text { Tempo }\end{array}$ & \multicolumn{3}{c}{$\begin{array}{c}\text { T1 } \\
\text { Repetição } \\
\text { (\%) }\end{array}$} & \multicolumn{3}{c}{ Média } & \multicolumn{4}{c}{$\begin{array}{c}\text { T2 } \\
\text { Repetição }\end{array}$} & Média \\
(h) & 1 & 2 & 3 & & 1 & 2 & 3 & \\
\hline 0 & 6,34 & 6,75 & 6,69 & 6,59 & 6,35 & 6,73 & 6,39 & 6,49 \\
24 & 5,48 & 5,66 & 5,24 & 5,46 & 5,12 & 5,45 & 5,55 & 5,37 \\
48 & 5,63 & 5,26 & 5,63 & 5,51 & 5,04 & 4,99 & 4,75 & 4,93 \\
72 & 5,40 & 5,17 & 5,59 & 5,39 & 5,31 & 5,52 & 5,22 & 5,35 \\
96 & 5,67 & 5,52 & 5,52 & 5,57 & 5,61 & 5,20 & 5,39 & 5,40 \\
120 & 3,80 & 4,11 & 3,55 & 3,82 & 3,13 & 4,34 & 3,70 & 3,72 \\
144 & 2,84 & 3,44 & 2,92 & 3,07 & - & 2,84 & 2,62 & 2,73 \\
168 & 5,06 & 3,46 & - & 4,26 & 2,38 & - & 3,31 & 2,85 \\
192 & 4,37 & 2,86 & 2,64 & 3,29 & 6,49 & 7,28 & 5,08 & 6,28 \\
\hline
\end{tabular}

Tabela 8. Carboidratos totais obtidos na suspensão celular de leveduras, após coleta de células e lavagem.

\begin{tabular}{ccccccccc}
\hline $\begin{array}{c}\text { Tratamento } \\
\text { Tempo }\end{array}$ & \multicolumn{3}{c}{ Repetição } & & Média & \multicolumn{3}{c}{ Repetição } \\
$(\mathrm{h})$ & 1 & 2 & 3 & $(\mathrm{~g} / \mathrm{L})$ & 1 & 2 & 3 & Média \\
\hline 0 & 1,80 & 1,76 & 1,81 & 1,79 & 1,79 & 1,44 & 1,71 & 1,65 \\
24 & 1,97 & 2,01 & 2,01 & 2,00 & 1,87 & 1,87 & 1,96 & 1,90 \\
48 & 1,94 & 1,92 & 1,94 & 1,93 & 1,87 & 1,81 & 1,94 & 1,87 \\
72 & 1,87 & 1,84 & 1,76 & 1,82 & 1,80 & 1,73 & 1,80 & 1,78 \\
96 & 1,81 & 1,80 & 1,80 & 1,80 & 1,79 & 1,73 & 1,66 & 1,73 \\
120 & 1,42 & 0,81 & 1,37 & 1,20 & 1,23 & 1,36 & 1,36 & 1,32 \\
144 & 1,16 & 1,47 & 0,44 & 1,02 & 0,09 & 1,37 & 1,14 & 0,87 \\
168 & 0,17 & 0,56 & 0,14 & 0,29 & 0,86 & 0,06 & 0,52 & 0,48 \\
192 & 0,31 & 1,53 & 1,55 & 1,13 & 0,06 & 0,08 & 0,14 & 0,09 \\
\hline
\end{tabular}


Tabela 9. Trealose em leveduras mantidas em condições não proliferantes ao longo de $192 \mathrm{~h}$. Teores percentuais em relação à matéria seca.

\begin{tabular}{ccccccccc}
\hline $\begin{array}{c}\text { Tratamento } \\
\text { Tempo }\end{array}$ & \multicolumn{3}{c}{ Repetição } & Média & \multicolumn{4}{c}{ Repetição } \\
\multicolumn{4}{c}{ (mg/100 mg de M.S.) } & $(\%)$ & \multicolumn{2}{c}{ Média } \\
(h) & 1 & 2 & 3 & & 1 & 2 & 3 & \\
\hline 0 & 0,48 & 0,29 & 0,41 & 0,39 & 0,52 & 0,30 & 0,45 & 0,42 \\
24 & 0,15 & 0,31 & 0,22 & 0,23 & 0,40 & 0,44 & 0,16 & 0,33 \\
48 & 0,19 & 0,28 & 0,29 & 0,25 & 0,13 & 0,07 & 0,07 & 0,09 \\
72 & 0,36 & 0,16 & 0,16 & 0,23 & 0,14 & 0,07 & 0,07 & 0,09 \\
96 & 0,17 & 0,18 & 0,21 & 0,19 & 0,05 & 0,03 & 0,04 & 0,04 \\
120 & 0,15 & 0,16 & 0,23 & 0,18 & 0,11 & 0,15 & 0,05 & 0,10 \\
144 & 0,22 & 0,07 & 0,26 & 0,18 & 0,51 & 0,15 & 0,34 & 0,33 \\
168 & 0,32 & 0,61 & 0,45 & 0,46 & 0,19 & 0,69 & 0,15 & 0,34 \\
192 & 0,00 & 0,00 & 0,00 & 0,00 & 0,00 & 0,00 & 0,00 & 0,00 \\
\hline
\end{tabular}


Tabela 10. Teores de trealose expressos em porcentagem dos carboidratos totais no decorrer de $192 \mathrm{~h}$, em condições não proliferantes de $S$. cerevisiae, em solução fisiológica de $\mathrm{KCl}$ 0,154M.

\begin{tabular}{ccccccccc}
\hline $\begin{array}{c}\text { Tratamento } \\
\text { Tempo }\end{array}$ & \multicolumn{3}{c}{$\begin{array}{c}\text { Repetição } \\
\text { (\%) }\end{array}$} & \multicolumn{3}{c}{ Média } & \multicolumn{4}{c}{$\begin{array}{c}\text { T2 } \\
\text { Repetição }\end{array}$} & Média \\
(h) & 1 & 2 & 3 & & 1 & 2 & 3 & \\
\hline 0 & 2,41 & 1,31 & 1,87 & 1,86 & 2,33 & 1,41 & 2,09 & 1,94 \\
24 & 0,68 & 1,45 & 1,06 & 1,06 & 1,92 & 2,16 & 0,76 & 1,61 \\
48 & 0,79 & 1,18 & 1,23 & 1,07 & 0,55 & 0,30 & 0,30 & 0,38 \\
72 & 1,46 & 0,66 & 0,70 & 0,94 & 0,54 & 0,28 & 0,29 & 0,37 \\
96 & 0,66 & 0,64 & 0,74 & 0,68 & 0,17 & 0,10 & 0,15 & 0,14 \\
120 & 0,54 & 0,68 & 0,86 & 0,69 & 0,38 & 0,53 & 0,17 & 0,36 \\
144 & 0,84 & 0,26 & 1,23 & 0,78 & 2,10 & 0,53 & 1,45 & 1,36 \\
168 & 2,54 & 3,30 & 1,74 & 2,53 & 0,61 & 3,48 & 0,59 & 1,56 \\
192 & 0,00 & 0,00 & 0,00 & 0,00 & 0,00 & 0,00 & 0,00 & 0,00 \\
\hline
\end{tabular}


Tabela 11. Glicogênio em leveduras. Teores percentuais em relação a matéria seca de $S$. cerevisiae mantida em condições não proliferantes ao longo de $192 \mathrm{~h}$.

\begin{tabular}{ccccccccc}
\hline $\begin{array}{c}\text { Tratamento } \\
\text { Tempo }\end{array}$ & \multicolumn{3}{c}{ Repetição } & Média & \multicolumn{4}{c}{ Repetição } \\
\multicolumn{4}{c}{ (mg/100 mg de M.S.) } & $(\%)$ & \multicolumn{2}{c}{ (mg/100 mg de M.S.) } & Média \\
(h) & 1 & 2 & 3 & & 1 & 2 & 3 & \\
\hline 0 & 4,67 & 3,70 & 4,33 & 4,23 & 4,40 & 3,68 & 3,55 & 3,88 \\
24 & 4,38 & 4,18 & 4,16 & 4,24 & 3,56 & 3,86 & 4,27 & 3,90 \\
48 & 3,67 & 4,72 & 2,99 & 3,79 & 3,94 & 3,86 & 4,43 & 4,08 \\
72 & 5,18 & 4,98 & - & 5,08 & 4,88 & 4,12 & 5,21 & 4,74 \\
96 & 5,04 & 5,84 & 5,84 & 5,57 & 5,44 & 5,60 & 4,97 & 5,34 \\
120 & 3,62 & 3,31 & 4,24 & 3,72 & 4,73 & 5,12 & 4,31 & 4,72 \\
144 & 3,93 & 6,12 & 2,99 & 4,35 & 1,08 & 5,55 & 3,49 & 3,37 \\
168 & 0,78 & 1,37 & 0,51 & 0,89 & 2,92 & 0,37 & 2,94 & 2,08 \\
192 & 0,00 & 0,00 & 0,00 & 0,00 & 0,00 & 0,00 & 0,00 & 0,00 \\
\hline
\end{tabular}




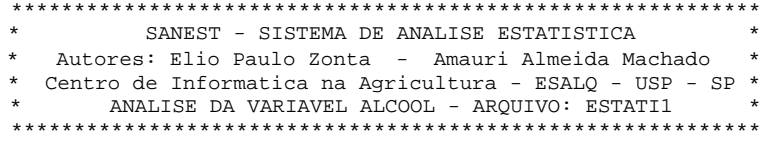

CODIGO DO PROJETO: 001

RESPONSAVEL: ANDRE E S BELLUCO

DELINEAMENTO EXPERIMENTAL: INTEIRAMENTE CASUALISADO

OBSERVACOES NAO TRANSFORMADAS

\begin{tabular}{cc} 
NOME DOS & FATORES \\
\hline------------ & NOME \\
FATOR & N \\
A & TRATA
\end{tabular}

QUADRO DA ANALISE DE VARIANCIA

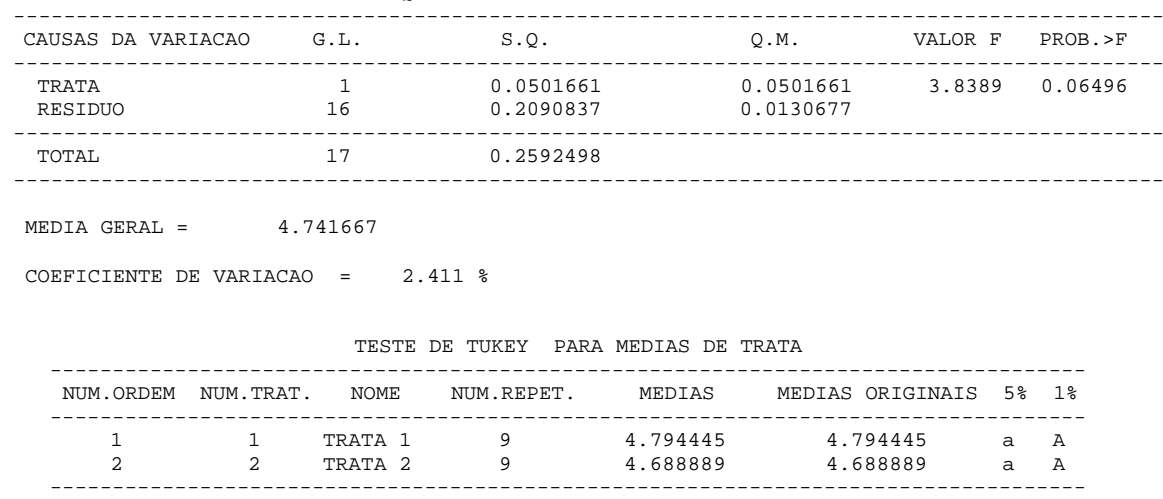

MEDIAS SEGUIDAS POR LETRAS DISTINTAS DIFEREM ENTRE SI AO NIVEL DE SIGNIFICANCIA INDICADO

D.M.S. $5 \%=0.11431-$ D.M.S. $1 \%=0.15737$

DIFEREM ENTRE SI AO NIVEL DE SIGNIFICANCIA INDICADO 


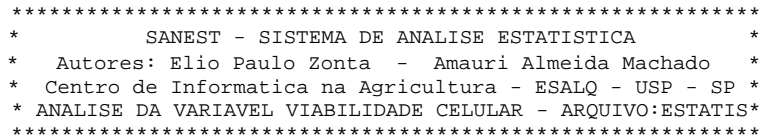

CODIGO DO PROJETO: 001

RESPONSAVEL: ANDRE E S BELLUCO

DELINEAMENTO EXPERIMENTAL: FATORIAL

OBSERVACOES NAO TRANSFORMADAS

\begin{tabular}{|c|c|}
\hline FATOR & NOME \\
\hline A & TRATA \\
\hline B & EPOCA \\
\hline
\end{tabular}

QUADRO DA ANALISE DE VARIANCIA

\begin{tabular}{|c|c|c|c|c|c|}
\hline CAUSAS DA VARIACAO & G.L. & S.Q. & Q.M. & VALOR F & PROB. $>\mathrm{F}$ \\
\hline TRATA & 1 & 68.6986480 & 68.6986480 & 8.6528 & 0.00796 \\
\hline EPOCA & 4 & 10299.7438967 & 2574.9359742 & 324.3225 & 0.00001 \\
\hline$T R A \star E P O$ & 4 & 440.4746434 & 110.1186609 & 13.8698 & 0.00006 \\
\hline RESIDUO & 20 & 158.7886180 & 7.9394309 & & \\
\hline TOTAL & 29 & 10967.7058061 & & & \\
\hline
\end{tabular}

MEDIA GERAL $=\quad 74.333336$

COEFICIENTE DE VARIACAO = $3.791 \%$

TESTE DE TUKEY PARA MEDIAS DE TRATA

\begin{tabular}{|c|c|c|c|c|c|c|c|c|}
\hline NUM. ORDEM & NUM. TRAT. & NOME & NUM. REPET. & MEDIAS & MEDIAS & ORIGINAIS & $5 \%$ & $1 \%$ \\
\hline 1 & 1 & TRATA 1 & 15 & 75.846665 & 75.8 & 846665 & a & A \\
\hline 2 & 2 & TRATA 2 & 15 & 72.819996 & 72.8 & 819996 & b & B \\
\hline
\end{tabular}

MEDIAS SEGUIDAS POR LETRAS DISTINTAS DIFEREM ENTRE SI AO NIVEL DE SIGNIFICANCIA INDICADO $\begin{array}{lll}\text { D.M.S. } 5 \%=2.14620-\text { D.M.S. } 1 \%=2.92466 & -20\end{array}$

TESTE DE TUKEY PARA MEDIAS DE TRATA

DENTRO DE EPOCA 1 DO FATOR EPOCA

\begin{tabular}{|c|c|c|c|c|c|c|c|c|}
\hline NUM. ORDEM & NUM. TRAT. & NOME & NUM. REPET. & MEDIAS & MEDIAS & ORIGINAIS & $5 \%$ & $1 \%$ \\
\hline 1 & 2 & TRATA 2 & 3 & 97.533325 & 97.5 & 533325 & a & A \\
\hline 2 & 1 & TRATA 1 & 3 & 97.099996 & 97.0 & 099996 & a & A \\
\hline
\end{tabular}

TESTE DE TUKEY PARA MEDIAS DE TRATA

DENTRO DE EPOCA 2 DO FATOR EPOCA

\begin{tabular}{|c|c|c|c|c|c|c|c|}
\hline NUM. ORDEM & NUM. TRAT. & NOME & NUM. REPET . & MEDIAS & MEDIAS ORIGINAIS & $5 \%$ & $1 \%$ \\
\hline 1 & 2 & TRATA 2 & 3 & 97.199992 & 97.199992 & a & A \\
\hline 2 & 1 & TRATA 1 & 3 & 94.633331 & 94.633331 & a & A \\
\hline
\end{tabular}

TESTE DE TUKEY PARA MEDIAS DE TRATA

DENTRO DE EPOCA 3 DO FATOR EPOCA

\begin{tabular}{|c|c|c|c|c|c|c|c|c|}
\hline NUM. ORDEM & NUM. TRAT . & NOME & NUM. REPET. & MEDIAS & MEDIAS & ORIGINAIS & $5 \%$ & $1 \%$ \\
\hline 1 & 1 & TRATA 1 & 3 & 65.366669 & 65.3 & 366669 & a & A \\
\hline 2 & 2 & TRATA 2 & 3 & 64.233332 & $64.2 x y \cdot x$ & 233332 & a & A \\
\hline
\end{tabular}

TESTE DE TUKEY PARA MEDIAS DE TRATA

DENTRO DE EPOCA 4 DO FATOR EPOCA

\begin{tabular}{|c|c|c|c|c|c|c|c|}
\hline NUM. ORDEM & NUM. TRAT. & NOME & NUM. REPET. & MEDIAS & MEDIAS ORIGINAIS & $5 \%$ & $1 \%$ \\
\hline 1 & 1 & TRATA 1 & 3 & 68.899999 & 68.899999 & a & A \\
\hline 2 & 2 & TRATA 2 & 3 & 50.733332 & 50.733332 & $\mathrm{~b}$ & B \\
\hline
\end{tabular}


TESTE DE TUKEY PARA MEDIAS DE TRATA

\begin{tabular}{|c|c|c|c|c|c|c|c|}
\hline NUM. ORDEM & NUM. TRAT. & NOME & NUM. REPET. & MEDIAS & MEDIAS ORIGINAIS & $5 \%$ & $1 \%$ \\
\hline 1 & 2 & TRATA 2 & 3 & 54.399999 & 54.399999 & a & A \\
\hline 2 & 1 & TRATA 1 & 3 & 53.233332 & 53.233332 & a & A \\
\hline
\end{tabular}

MEDIAS SEGUIDAS POR LETRAS DISTINTAS DIFEREM ENTRE SI AO NIVEL DE SIGNIFICANCIA INDICADO D.M.S. $5 \%=4.79906-$ D.M.S. $1 \%=6.53973$

TESTE DE TUKEY PARA MEDIAS DE EPOCA

\begin{tabular}{|c|c|c|c|c|c|c|c|}
\hline NUM. ORDEM & NUM. TRAT. & NOME & NUM. REPET. & MEDIAS & MEDIAS ORIGINAIS & $5 \%$ & $1 \frac{\circ}{\circ}$ \\
\hline 1 & 1 & EPOCA 1 & 6 & 97.316661 & 97.316661 & a & A \\
\hline 2 & 2 & EPOCA 2 & 6 & 95.916662 & 95.916662 & a & A \\
\hline 3 & 3 & EPOCA 3 & 6 & 64.800001 & 64.800001 & b & B \\
\hline 4 & 4 & EPOCA 4 & 6 & 59.816666 & 59.816666 & C & $\mathrm{BC}$ \\
\hline 5 & 5 & EPOCA 5 & 6 & 53.816666 & 53.816666 & d & $\mathrm{C}$ \\
\hline
\end{tabular}

MEDIAS SEGUIDAS POR LETRAS DISTINTAS DIFEREM ENTRE SI AO NIVEL DE SIGNIFICANCIA INDICADO D.M.S. $5 \%=4.86586-$ D.M.S. $1 \%=6.08520$

TESTE DE TUKEY PARA MEDIAS DE EPOCA

DENTRO DE TRATA 1 DO FATOR TRATA

\begin{tabular}{|c|c|c|c|c|c|c|c|}
\hline NUM. ORDEM & NUM. TRAT. & NOME & NUM. REPET. & MEDIAS & MEDIAS ORIGINAIS & $5 \%$ & $1 \%$ \\
\hline 1 & 1 & EPOCA 1 & 3 & 97.099996 & 97.099996 & a & A \\
\hline 2 & 2 & EPOCA 2 & 3 & 94.633331 & 94.633331 & a & A \\
\hline 3 & 4 & EPOCA 4 & 3 & 68.899999 & 68.899999 & b & B \\
\hline 4 & 3 & EPOCA 3 & 3 & 65.366669 & 65.366669 & b & B \\
\hline 5 & 5 & EPOCA 5 & 3 & 53.233332 & 53.233332 & c & C \\
\hline
\end{tabular}

TESTE DE TUKEY PARA MEDIAS DE EPOCA

DENTRO DE TRATA 2 DO FATOR TRATA

\begin{tabular}{|c|c|c|c|c|c|c|c|}
\hline NUM. ORDEM & NUM. TRAT. & NOME & NUM. REPET. & MEDIAS & MEDIAS ORIGINAIS & $5 \%$ & $1 \%$ \\
\hline 1 & 1 & EPOCA 1 & 3 & 97.533325 & 97.533325 & a & A \\
\hline 2 & 2 & EPOCA 2 & 3 & 97.199992 & 97.199992 & a & A \\
\hline 3 & 3 & EPOCA 3 & 3 & 64.233332 & 64.233332 & $\mathrm{~b}$ & B \\
\hline 4 & 5 & EPOCA 5 & 3 & 54.399999 & 54.399999 & $\mathrm{c}$ & $\mathrm{C}$ \\
\hline 5 & 4 & EPOCA 4 & 3 & 50.733332 & 50.733332 & $\mathrm{c}$ & $\mathrm{C}$ \\
\hline
\end{tabular}

MEDIAS SEGUIDAS POR LETRAS DISTINTAS DIFEREM ENTRE SI AO NIVEL DE SIGNIFICANCIA INDICADO

D.M.S. $5 \%=6.88136-$ D.M.S. $1 \%=60577$ 


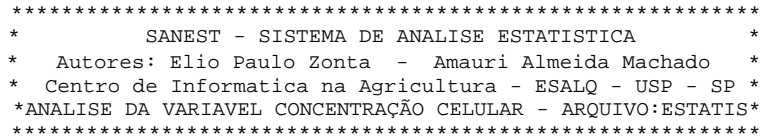

*ANALISE DA VARIAVEL CONCENTRAÇÃO CELULAR - ARQUIVO:ESTATIS*

CODIGO DO PROJETO: 001

RESPONSAVEL: ANDRE E S BELLUCO

DELINEAMENTO EXPERIMENTAL: FATORIAL

OBSERVACOES NAO TRANSFORMADAS

\begin{tabular}{|c|c|}
\hline FATOR & NOME \\
\hline A & TRATA \\
\hline B & EPOCA \\
\hline
\end{tabular}

QUADRO DA ANALISE DE VARIANCIA

\begin{tabular}{|c|c|c|c|c|c|}
\hline CAUSAS DA VARIACAO & G.L. & S.Q. & Q.M. & VALOR F & PROB. $>$ F \\
\hline TRATA & 1 & 1.5869924 & 1.5869924 & 12.7619 & 0.00220 \\
\hline EPOCA & 4 & 28.5798419 & 7.1449605 & 57.4567 & 0.00001 \\
\hline $\mathrm{TRA} * \mathrm{EPO}$ & 4 & 0.4824736 & 0.1206184 & 0.9700 & 0.55293 \\
\hline RESIDUO & 20 & 2.4870763 & 0.1243538 & & \\
\hline TOTAL & 29 & 33.1363842 & & & \\
\hline
\end{tabular}

MEDIA GERAL $=\quad 7.787334$

COEFICIENTE DE VARIACAO $=4.528 \%$

TESTE DE TUKEY PARA MEDIAS DE TRATA

\begin{tabular}{|c|c|c|c|c|c|c|c|c|}
\hline NUM. ORDEM & NUM. TRAT. & NOME & NUM. REPET. & MEDIAS & MEDIAS & ORIGINAIS & $5 \%$ & $1 \%$ \\
\hline 1 & 1 & TRATA 1 & 15 & 8.017333 & & 017333 & a & A \\
\hline 2 & 2 & TRATA 2 & 15 & 7.557333 & 7.5 & 557333 & b & B \\
\hline
\end{tabular}

MEDIAS SEGUIDAS POR LETRAS DISTINTAS DIFEREM ENTRE SI AO NIVEL DE SIGNIFICANCIA INDICADO $\begin{array}{llll}\text { D.M.S. } 5 \% & =0.26860-\text { D.M.S. } 1 \%=0 & 0.36602\end{array}$

MEDIAS DO FATOR TRATA

DENTRO DE EPOCA 1 DO FATOR EPOCA

\begin{tabular}{|c|c|c|c|c|}
\hline NUM. TRAT. & NOME & NUM. REPET. & MEDIAS & MEDIAS ORIGINAIS \\
\hline 1 & TRATA 1 & 3 & 8.410000 & 8.410000 \\
\hline 2 & TRATA 2 & 3 & 7.593334 & 7.593334 \\
\hline
\end{tabular}

MEDIAS DO FATOR TRATA

DENTRO DE EPOCA 2 DO FATOR EPOCA

\begin{tabular}{|c|c|c|c|c|}
\hline NUM. TRAT. & NOME & NUM. REPET. & MEDIAS & MEDIAS ORIGINAIS \\
\hline 1 & $\begin{array}{ll}\text { TRATA } & 1\end{array}$ & 3 & 9.370000 & 9.370000 \\
\hline 2 & TRATA 2 & 3 & 9.146666 & 9.146666 \\
\hline
\end{tabular}

MEDIAS DO FATOR TRATA

DENTRO DE EPOCA 3 DO FATOR EPOCA

$\begin{array}{ccccc}-1 & \\ \text { NUM. TRAT. } & \text { NOME } & \text { NUM. REPET. } & \text { MEDIAS } & \text { MEDIAS ORIGINAIS } \\ -1 & \text { TRATA } 1 & 3 & 8.106667 & 8.106667 \\ 2 & \text { TRATA } 2 & 3 & 7.983334 & 7.983334 \\ -\end{array}$

MEDIAS DO FATOR TRATA

DENTRO DE EPOCA 4 DO FATOR EPOCA

\begin{tabular}{|c|c|c|c|c|}
\hline NUM. TRAT. & NOME & NUM. REPET . & MEDIAS & MEDIAS ORIGINAIS \\
\hline 1 & TRATA 1 & 3 & 7.633333 & 7.633333 \\
\hline 2 & TRATA 2 & 3 & 7.093334 & 7.093334 \\
\hline
\end{tabular}


MEDIAS DO FATOR TRATA

DENTRO DE FPOCA 5 DO FATOR EPOCA

\begin{tabular}{|c|c|c|c|c|}
\hline NUM. TRAT. & NOME & NUM. REPET. & MEDIAS & MEDIAS ORIGINAIS \\
\hline 1 & TRATA 1 & 3 & 6.566667 & 6.566667 \\
\hline 2 & TRATA 2 & 3 & 5.970000 & 5.970000 \\
\hline
\end{tabular}

TESTE DE TUKEY PARA MEDIAS DE EPOCA

\begin{tabular}{|c|c|c|c|c|c|c|c|}
\hline NUM. ORDEM & NUM. TRAT. & NOME & NUM. REPET. & MEDIAS & MEDIAS ORIGINAIS & $5 \%$ & $1 \%$ \\
\hline 1 & 2 & EPOCA 2 & 6 & 9.258333 & 9.258333 & a & A \\
\hline 2 & 3 & EPOCA 3 & 6 & 8.045000 & 8.045000 & $\mathrm{~b}$ & B \\
\hline 3 & 1 & EPOCA 1 & 6 & 8.001667 & 8.001667 & $\mathrm{~b}$ & B \\
\hline 4 & 4 & EPOCA 4 & 6 & 7.363333 & 7.363333 & C & B \\
\hline 5 & 5 & EPOCA 5 & 6 & 6.268333 & 6.268333 & d & $\mathrm{C}$ \\
\hline
\end{tabular}

MEDIAS SEGUIDAS POR LETRAS DISTINTAS DIFEREM ENTRE SI AO NIVEL DE SIGNIFICANCIA INDICADO D.M.S. $5 \%=0.60897$ - D.M.S. $1 \%=0.76157$

MEDIAS DO FATOR EPOCA

DENTRO DE TRATA 1 DO FATOR TRATA

\begin{tabular}{|c|c|c|c|c|}
\hline NUM. TRAT. & NOME & NUM. REPET. & MEDIAS & MEDIAS ORIGINAIS \\
\hline 1 & EPOCA 1 & 3 & 8.410000 & 8.410000 \\
\hline 2 & EPOCA 2 & 3 & 9.370000 & 9.370000 \\
\hline 3 & EPOCA 3 & 3 & 8.106667 & 8.106667 \\
\hline 4 & EPOCA 4 & 3 & 7.633333 & 7.633333 \\
\hline 5 & EPOCA 5 & 3 & 6.566667 & 6.566667 \\
\hline
\end{tabular}

MEDIAS DO FATOR EPOCA

DENTRO DE TRATA 2 DO FATOR TRATA

\begin{tabular}{|c|c|c|c|c|}
\hline NUM. TRAT. & NOME & NUM. REPET. & MEDIAS & MEDIAS ORIGINAIS \\
\hline 1 & EPOCA 1 & 3 & 7.593334 & 7.593334 \\
\hline 2 & EPOCA 2 & 3 & 9.146666 & 9.146666 \\
\hline 3 & EPOCA 3 & 3 & 7.983334 & 7.983334 \\
\hline 4 & EPOCA 4 & 3 & 7.093334 & 7.093334 \\
\hline 5 & EPOCA 5 & 3 & 5.970000 & 5.970000 \\
\hline
\end{tabular}




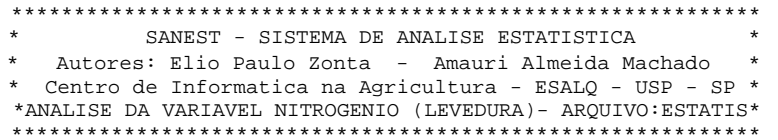

${ }^{*}$ ANALISE DA VARIAVEL NITROGENIO (LEVEDURA) - ARQUIVO:ESTATIS*

CODIGO DO PROJETO: 001

RESPONSAVEL: ANDRE E S BELLUCO

DELINEAMENTO EXPERIMENTAL: FATORIAL

OBSERVACOES NAO TRANSFORMADAS

\begin{tabular}{|c|c|}
\hline FATOR & NOME \\
\hline A & TRATA \\
\hline B & EPOCA \\
\hline
\end{tabular}

QUADRO DA ANALISE DE VARIANCIA

\begin{tabular}{|c|c|c|c|c|c|}
\hline CAUSAS DA VARIACAO & G.L. & S.Q. & Q.M. & VALOR F & PROB. $>\mathrm{F}$ \\
\hline TRATA & 1 & 132.7600421 & 132.7600421 & 30.4250 & 0.00009 \\
\hline EPOCA & 4 & 1325.1322031 & 331.2830508 & 75.9211 & 0.00001 \\
\hline $\mathrm{TRA} \star \mathrm{EPO}$ & 4 & 17.3578984 & 4.3394746 & 0.9945 & 0.56540 \\
\hline RESIDUO & 20 & 87.2703342 & 4.3635167 & & \\
\hline TOTAL & 29 & 1562.5204778 & & & \\
\hline
\end{tabular}

MEDIA GERAL $=\quad 43.659668$

COEFICIENTE DE VARIACAO $=4.785 \%$

TESTE DE TUKEY PARA MEDIAS DE TRATA

\begin{tabular}{|c|c|c|c|c|c|c|c|c|}
\hline NUM. ORDEM & NUM. TRAT. & NOME & NUM. REPET. & MEDIAS & MEDIAS & ORIGINAIS & $5 \%$ & $1 \%$ \\
\hline 1 & 1 & TRATA 1 & 15 & 45.763332 & 45.7 & 763332 & a & A \\
\hline 2 & 2 & TRATA 2 & 15 & 41.555999 & 41.5 & 555999 & b & B \\
\hline
\end{tabular}

MEDIAS SEGUIDAS POR LETRAS DISTINTAS DIFEREM ENTRE SI AO NIVEL DE SIGNIFICANCIA INDICADO

$\begin{array}{lll}\text { D.M.S. } 5 \% & =1.59109-\text { D.M.S. } 1 \frac{\circ}{0}=2.16820\end{array}$

MEDIAS DO FATOR TRATA

DENTRO DE EPOCA 1 DO FATOR EPOCA

\begin{tabular}{|c|c|c|c|c|}
\hline NUM. TRAT. & NOME & NUM. REPET. & MEDIAS & MEDIAS ORIGINAIS \\
\hline 1 & TRATA 1 & 3 & 55.356669 & 55.356669 \\
\hline 2 & TRATA 2 & 3 & 49.153330 & 49.153330 \\
\hline
\end{tabular}

MEDIAS DO FATOR TRATA

DENTRO DE EPOCA 2 DO FATOR EPOCA

$\begin{array}{ccccc}- \text { NUM.TRAT. } & \text { NOME } & \text { NUM. REPET. } & \text { MEDIAS } & \text { MEDIAS ORIGINAIS } \\ -1 & \text { TRATA } 1 & 3 & 51.089996 & 51.089996 \\ 2 & \text { TRATA } 2 & 3 & 49.156667 & 49.156667 \\ -\end{array}$

MEDIAS DO FATOR TRATA

DENTRO DE EPOCA 3 DO FATOR EPOCA

\begin{tabular}{|c|c|c|c|c|}
\hline NUM. TRAT. & NOME & NUM. REPET . & MEDIAS & MEDIAS ORIGINAIS \\
\hline 1 & TRATA 1 & 3 & 44.643331 & 44.643331 \\
\hline 2 & TRATA 2 & 3 & 39.283333 & 39.283333 \\
\hline
\end{tabular}

MEDIAS DO FATOR TRATA

DENTRO DE EPOCA 4 DO FATOR EPOCA

\begin{tabular}{|c|c|c|c|c|}
\hline NUM. TRAT. & NOME & NUM. REPET . & MEDIAS & MEDIAS ORIGINAIS \\
\hline 1 & TRATA 1 & 3 & 41.120000 & 41.120000 \\
\hline 2 & TRATA 2 & 3 & 37.943334 & 37.943334 \\
\hline
\end{tabular}


MEDIAS DO FATOR TRATA

DENTRO DE FPOCA 5 DO FATOR EPOCA

\begin{tabular}{|c|c|c|c|c|}
\hline NUM. TRAT. & NOME & NUM. REPET. & MEDIAS & MEDIAS ORIGINAIS \\
\hline 1 & TRATA 1 & 3 & 36.606664 & 36.606664 \\
\hline 2 & TRATA 2 & 3 & 32.243332 & 32.243332 \\
\hline
\end{tabular}

TESTE DE TUKEY PARA MEDIAS DE EPOCA

\begin{tabular}{|c|c|c|c|c|c|c|c|}
\hline NUM. ORDEM & NUM. TRAT. & NOME & NUM. REPET. & MEDIAS & MEDIAS ORIGINAIS & $5 \%$ & $1 \%$ \\
\hline 1 & 1 & EPOCA 1 & 6 & 52.255000 & 52.255000 & a & A \\
\hline 2 & 2 & EPOCA 2 & 6 & 50.123332 & 50.123332 & a & A \\
\hline 3 & 3 & EPOCA 3 & 6 & 41.963332 & 41.963332 & $\mathrm{~b}$ & B \\
\hline 4 & 4 & EPOCA 4 & 6 & 39.531667 & 39.531667 & $\mathrm{~b}$ & B \\
\hline 5 & 5 & EPOCA 5 & 6 & 34.424998 & 34.424998 & c & $\mathrm{C}$ \\
\hline
\end{tabular}

MEDIAS SEGUIDAS POR LETRAS DISTINTAS DIFEREM ENTRE SI AO NIVEL DE SIGNIFICANCIA INDICADO D.M.S. $5 \%=3.60731-$ D.M.S. $1 \%=4.51127$

MEDIAS DO FATOR EPOCA

DENTRO DE TRATA 1 DO FATOR TRATA

\begin{tabular}{|c|c|c|c|c|}
\hline NUM. TRAT. & NOME & NUM. REPET. & MEDIAS & MEDIAS ORIGINAIS \\
\hline 1 & EPOCA 1 & 3 & 55.356669 & 55.356669 \\
\hline 2 & EPOCA 2 & 3 & 51.089996 & 51.089996 \\
\hline 3 & EPOCA 3 & 3 & 44.643331 & 44.643331 \\
\hline 4 & EPOCA 4 & 3 & 41.120000 & 41.120000 \\
\hline 5 & EPOCA 5 & 3 & 36.606664 & 36.606664 \\
\hline
\end{tabular}

MEDIAS DO FATOR EPOCA

DENTRO DE TRATA 2 DO FATOR TRATA

-
NUM. TRAT.




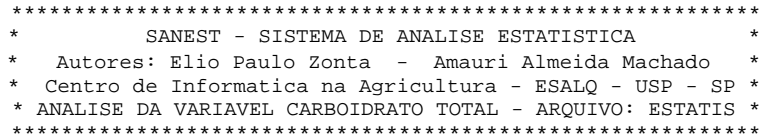

* anAlise da VARIAVel CARBoidrato total - ARQUivo: estatis *

CODIGO DO PROJETO: 001

RESPONSAVEL: ANDRE E S BELLUCO

DELINEAMENTO EXPERIMENTAL: FATORIAL

OBSERVACOES NAO TRANSFORMADAS

\begin{tabular}{|c|c|}
\hline FATOR & NOME \\
\hline A & TRATA \\
\hline B & EPOCA \\
\hline
\end{tabular}

QUADRO DA ANALISE DE VARIANCIA

\begin{tabular}{|c|c|c|c|c|c|}
\hline CAUSAS DA VARIACAO & G.L. & S.Q. & Q.M. & VALOR F & PROB. $>\mathrm{F}$ \\
\hline TRATA & 1 & 0.0537621 & 0.0537621 & 10.5277 & 0.00425 \\
\hline EPOCA & 4 & 0.2215786 & 0.0553947 & 10.8474 & 0.00018 \\
\hline $\mathrm{TRA} * \mathrm{EPO}$ & 4 & 0.0085546 & 0.0021387 & 0.4188 & 0.79471 \\
\hline RESIDUO & 20 & 0.1021347 & 0.0051067 & & \\
\hline TOTAL & 29 & 0.3860300 & & & \\
\hline
\end{tabular}

MEDIA GERAL $=\quad 1.827000$

COEFICIENTE DE VARIACAO $=3.911 \%$

TESTE DE TUKEY PARA MEDIAS DE TRATA

\begin{tabular}{|c|c|c|c|c|c|c|c|c|}
\hline NUM. ORDEM & NUM. TRAT. & NOME & NUM. REPET. & MEDIAS & MEDIAS & ORIGINAIS & $5 \%$ & $1 \%$ \\
\hline 1 & 1 & TRATA 1 & 15 & 1.869333 & & 869333 & a & A \\
\hline 2 & 2 & TRATA 2 & 15 & 1.784667 & 1.7 & 784667 & b & B \\
\hline
\end{tabular}

MEDIAS SEGUIDAS POR LETRAS DISTINTAS DIFEREM ENTRE SI AO NIVEL DE SIGNIFICANCIA INDICADO D.M.S. $5 \%=0.05443-$ D.M.S. $1 \%=0.07417$

MEDIAS DO FATOR TRATA DENTRO DE EPOCA 1 DO FATOR EPOCA

\begin{tabular}{ccccc}
-1.79 & & & \\
NUM. TRAT. & NOME & NUM. REPET. & MEDIAS & MEDIAS ORIGINAIS \\
-1 & TRATA 1 & 3 & 1.790000 & 1.790000 \\
2 & TRATA 2 & 3 & 1.646667 & 1.646667 \\
\hline
\end{tabular}

MEDIAS DO FATOR TRATA

DENTRO DE EPOCA 2 DO FATOR EPOCA

\begin{tabular}{|c|c|c|c|c|}
\hline NUM. TRAT. & NOME & NUM. REPET. & MEDIAS & MEDIAS ORIGINAIS \\
\hline 1 & TRATA 1 & 3 & 1.996667 & 1.996667 \\
\hline 2 & TRATA 2 & 3 & 1.900000 & 1.900000 \\
\hline
\end{tabular}

MEDIAS DO FATOR TRATA

DENTRO DE EPOCA 3 DO FATOR EPOCA

\begin{tabular}{|c|c|c|c|c|}
\hline NUM. TRAT. & NOME & NUM. REPET . & MEDIAS & MEDIAS ORIGINAIS \\
\hline 1 & TRATA 1 & 3 & 1.933333 & 1.933333 \\
\hline 2 & TRATA 2 & 3 & 1.873333 & 1.873333 \\
\hline
\end{tabular}

MEDIAS DO FATOR TRATA

DENTRO DE EPOCA 4 DO FATOR EPOCA

\begin{tabular}{|c|c|c|c|c|}
\hline NUM. TRAT. & NOME & NUM. REPET. & MEDIAS & MEDIAS ORIGINAIS \\
\hline 1 & TRATA 1 & 3 & 1.823333 & 1.823333 \\
\hline 2 & TRATA 2 & 3 & 1.776667 & 1.776667 \\
\hline
\end{tabular}


MEDIAS DO FATOR TRATA

DENTRO DE FPOCA 5 DO FATOR FPOCA

\begin{tabular}{|c|c|c|c|c|}
\hline NUM. TRAT. & NOME & NUM. REPET. & MEDIAS & MEDIAS ORIGINAIS \\
\hline 1 & TRATA 1 & 3 & 1.803333 & 1.803333 \\
\hline 2 & TRATA 2 & 3 & 1.726667 & 1.726667 \\
\hline
\end{tabular}

TESTE DE TUKEY PARA MEDIAS DE EPOCA

\begin{tabular}{|c|c|c|c|c|c|c|c|}
\hline NUM. ORDEM & NUM. TRAT. & NOME & NUM. REPET. & MEDIAS & MEDIAS ORIGINAIS & $5 \%$ & $1 \%$ \\
\hline 1 & 2 & EPOCA 2 & 6 & 1.948333 & 1.948333 & $\mathrm{a}$ & A \\
\hline 2 & 3 & EPOCA 3 & 6 & 1.903333 & 1.903333 & $a b$ & $A B$ \\
\hline 3 & 4 & EPOCA 4 & 6 & 1.800000 & 1.800000 & $\mathrm{bc}$ & $\mathrm{ABC}$ \\
\hline 4 & 5 & EPOCA 5 & 6 & 1.765000 & 1.765000 & $\mathrm{c}$ & $\mathrm{BC}$ \\
\hline 5 & 1 & EPOCA 1 & 6 & 1.718333 & 1.718333 & c & $\mathrm{C}$ \\
\hline
\end{tabular}

MEDIAS SEGUIDAS POR LETRAS DISTINTAS DIFEREM ENTRE SI AO NIVEL DE SIGNIFICANCIA INDICADO D.M.S. $5 \%=0.12341$ - D.M.S. $1 \%=0.15433$

MEDIAS DO FATOR EPOCA

DENTRO DE TRATA 1 DO FATOR TRATA

\begin{tabular}{ccccc}
--1 & & & \\
NUM. TRAT. & NOME & NUM. REPET. & MEDIAS & MEDIAS ORIGINAIS \\
---1 & EPOCA 1 & 3 & 1.790000 & 1.790000 \\
2 & EPOCA 2 & 3 & 1.996667 & 1.996667 \\
3 & EPOCA 3 & 3 & 1.933333 & 1.933333 \\
4 & EPOCA 4 & 3 & 1.823333 & 1.823333 \\
5 & EPOCA 5 & 3 & 1.803333 & 1.803333 \\
\hline
\end{tabular}

MEDIAS DO FATOR EPOCA

DENTRO DE TRATA 2 DO FATOR TRATA

\begin{tabular}{|c|c|c|c|c|}
\hline NUM. TRAT. & NOME & NUM. REPET. & MEDIAS & MEDIAS ORIGINAIS \\
\hline 1 & EPOCA 1 & 3 & 1.646667 & 1.646667 \\
\hline 2 & EPOCA 2 & 3 & 1.900000 & 1.900000 \\
\hline 3 & EPOCA 3 & 3 & 1.873333 & 1.873333 \\
\hline 4 & EPOCA 4 & 3 & 1.776667 & 1.776667 \\
\hline 5 & EPOCA 5 & 3 & 1.726667 & 1.726667 \\
\hline
\end{tabular}




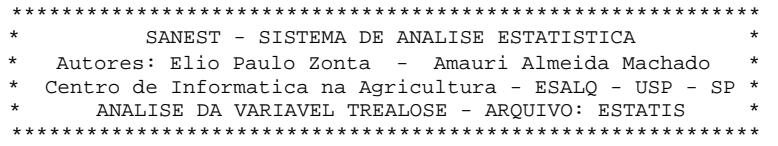

CODIGO DO PROJETO: 001

RESPONSAVEL: ANDRE E S BELLUCO

DELINEAMENTO EXPERIMENTAL: FATORIAL

OBSERVACOES NAO TRANSFORMADAS

\begin{tabular}{|c|c|}
\hline FATOR & NOME \\
\hline A & TRATA \\
\hline B & EPOCA \\
\hline
\end{tabular}

QUADRO DA ANALISE DE VARIANCIA

\begin{tabular}{|c|c|c|c|c|c|}
\hline CAUSAS DA VARIACAO & G.L. & $S \cdot Q$. & Q.M. & VALOR F & PROB. $>\mathrm{F}$ \\
\hline TRATA & 1 & 0.0282133 & 0.0282133 & 3.9756 & 0.05723 \\
\hline EPOCA & 4 & 0.3369666 & 0.0842417 & 11.8706 & 0.00012 \\
\hline $\mathrm{TRA} * \mathrm{EPO}$ & 4 & 0.0891534 & 0.0222883 & 3.1407 & 0.03667 \\
\hline RESIDUO & 20 & 0.1419334 & 0.0070967 & & \\
\hline TOTAL & 29 & 0.5962666 & & & \\
\hline
\end{tabular}

MEDIA GERAL $=\quad 0.226667$

COEFICIENTE DE VARIACAO $=37.165 \%$

TESTE DE TUKEY PARA MEDIAS DE TRATA

\begin{tabular}{|c|c|c|c|c|c|c|c|}
\hline NUM. ORDEM & NUM. TRAT. & NOME & NUM. REPET. & MEDIAS & MEDIAS ORIGINAIS & $5 \%$ & $1 \%$ \\
\hline 1 & 1 & TRATA 1 & 15 & 0.257333 & 0.257333 & a & A \\
\hline 2 & 2 & TRATA 2 & 15 & 0.196000 & 0.196000 & $\mathrm{a}$ & A \\
\hline
\end{tabular}

MEDIAS SEGUIDAS POR LETRAS DISTINTAS DIFEREM ENTRE SI AO NIVEL DE SIGNIFICANCIA INDICADO D.M.S. $5 \%=0.06417-$ D.M.S. $1 \%=0.08744$

TESTE DE TUKEY PARA MEDIAS DE TRATA

DENTRO DE EPOCA 1 DO FATOR EPOCA

-
NUM. ORDEM NUM. TRAT.

TESTE DE TUKEY PARA MEDIAS DE TRATA

DENTRO DE EPOCA 2 DO FATOR EPOCA

\begin{tabular}{|c|c|c|c|c|c|c|c|}
\hline NUM. ORDEM & NUM. TRAT. & NOME & NUM. REPET. & MEDIAS & MEDIAS ORIGINAIS & $5 \%$ & $1 \%$ \\
\hline 1 & 2 & TRATA 2 & 3 & 0.333333 & 0.333333 & a & A \\
\hline 2 & 1 & TRATA 1 & 3 & 0.226667 & 0.226667 & a & A \\
\hline
\end{tabular}

TESTE DE TUKEY PARA MEDIAS DE TRATA

DENTRO DE EPOCA 3 DO FATOR EPOCA

\begin{tabular}{|c|c|c|c|c|c|c|c|c|}
\hline NUM. ORDEM & NUM. TRAT. & NOME & NUM. REPET. & MEDIAS & MEDIAS & ORIGINAIS & $5 \%$ & $1 \%$ \\
\hline 1 & 1 & TRATA 1 & 3 & 0.253333 & & 253333 & a & A \\
\hline 2 & 2 & TRATA 2 & 3 & 0.090000 & 0.0 & 090000 & b & A \\
\hline
\end{tabular}

TESTE DE TUKEY PARA MEDIAS DE TRATA

DENTRO DE EPOCA 4 DO FATOR EPOCA

\begin{tabular}{|c|c|c|c|c|c|c|c|c|}
\hline NUM. ORDEM & NUM. TRAT. & NOME & NUM. REPET. & MEDIAS & MEDIAS & ORIGINAIS & $5 \%$ & $1 \%$ \\
\hline 1 & 1 & TRATA 1 & 3 & 0.226667 & 0.2 & 226667 & a & A \\
\hline 2 & 2 & TRATA 2 & 3 & 0.093333 & 0. & 093333 & a & A \\
\hline
\end{tabular}


TESTE DE TUKEY PARA MEDIAS DE TRATA

\begin{tabular}{|c|c|c|c|c|c|c|c|}
\hline NUM. ORDEM & NUM. TRAT. & NOME & NUM. REPET. & MEDIAS & MEDIAS ORIGINAIS & $5 \%$ & $1 \%$ \\
\hline 1 & 1 & TRATA 1 & 3 & 0.186667 & 0.186667 & a & A \\
\hline 2 & 2 & TRATA 2 & 3 & 0.040000 & 0.040000 & $\mathrm{~b}$ & A \\
\hline
\end{tabular}

MEDIAS SEGUIDAS POR LETRAS DISTINTAS DIFEREM ENTRE SI AO NIVEL DE SIGNIFICANCIA INDICADO D.M.S. $5 \%=0.14348-$ D.M.S. $1 \%=0.19552$

TESTE DE TUKEY PARA MEDIAS DE EPOCA

\begin{tabular}{cccccccc} 
NUM. ORDEM & NUM. TRAT. & NOME & NUM. REPET. & MEDIAS & MEDIAS ORIGINAIS & 5\% & $1 \%$ \\
-1 & 1 & EPOCA 1 & 6 & 0.408333 & 0.408333 & a & A \\
2 & 2 & EPOCA 2 & 6 & 0.280000 & 0.280000 & ab & AB \\
3 & 3 & EPOCA 3 & 6 & 0.171667 & 0.171667 & $\mathrm{bC}$ & $\mathrm{B}$ \\
4 & 4 & EPOCA 4 & 6 & 0.160000 & 0.160000 & $\mathrm{bC}$ & $\mathrm{B}$ \\
5 & 5 & EPOCA 5 & 6 & 0.113333 & 0.113333 & $\mathrm{C}$ & $\mathrm{B}$ \\
\hline
\end{tabular}

MEDIAS SEGUIDAS POR LETRAS DISTINTAS DIFEREM ENTRE SI AO NIVEL DE SIGNIFICANCIA INDICADO D.M.S. $5 \%=0.14548-$ D.M.S. $1 \%=0.18193$

TESTE DE TUKEY PARA MEDIAS DE EPOCA

DENTRO DE TRATA 1 DO FATOR TRATA

\begin{tabular}{|c|c|c|c|c|c|c|c|}
\hline NUM. ORDEM & NUM. TRAT. & NOME & NUM. REPET. & MEDIAS & MEDIAS ORIGINAIS & $5 \%$ & $1 \%$ \\
\hline 1 & 1 & EPOCA 1 & 3 & 0.393333 & 0.393333 & a & A \\
\hline 2 & 3 & EPOCA 3 & 3 & 0.253333 & 0.253333 & $a b$ & A \\
\hline 3 & 2 & EPOCA 2 & 3 & 0.226667 & 0.226667 & $a b$ & A \\
\hline 4 & 4 & EPOCA 4 & 3 & 0.226667 & 0.226667 & $a b$ & A \\
\hline 5 & 5 & EPOCA 5 & 3 & 0.186667 & 0.186667 & $\mathrm{~b}$ & A \\
\hline
\end{tabular}

TESTE DE TUKEY PARA MEDIAS DE EPOCA

DENTRO DE TRATA 2 DO FATOR TRATA

\begin{tabular}{|c|c|c|c|c|c|c|c|}
\hline NUM. ORDEM & NUM. TRAT. & NOME & NUM. REPET . & MEDIAS & MEDIAS ORIGINAIS & $5 \%$ & $1 \%$ \\
\hline 1 & 1 & EPOCA 1 & 3 & 0.423333 & 0.423333 & a & A \\
\hline 2 & 2 & EPOCA 2 & 3 & 0.333333 & 0.333333 & a & $A B$ \\
\hline 3 & 4 & EPOCA 4 & 3 & 0.093333 & 0.093333 & $\mathrm{~b}$ & $\mathrm{BC}$ \\
\hline 4 & 3 & EPOCA 3 & 3 & 0.090000 & 0.090000 & $\mathrm{~b}$ & $\mathrm{BC}$ \\
\hline 5 & 5 & EPOCA 5 & 3 & 0.040000 & 0.040000 & $\mathrm{~b}$ & $\mathrm{C}$ \\
\hline
\end{tabular}

MEDIAS SEGUIDAS POR LETRAS DISTINTAS DIFEREM ENTRE SI AO NIVEL DE SIGNIFICANCIA INDICADO

D.M.S. $5 \%=0.20573-$ D.M.S. $1 \%=0.25729$ 


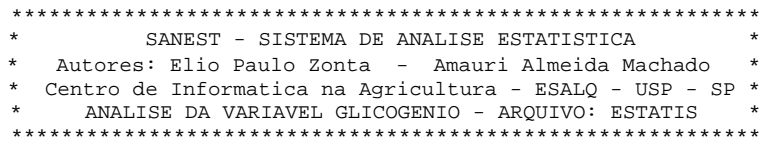

CODIGO DO PROJETO: 001

RESPONSAVEL: ANDRE E S BELLUCO

DELINEAMENTO EXPERIMENTAL: FATORIAL

OBSERVACOES NAO TRANSFORMADAS

\begin{tabular}{|c|c|}
\hline FATOR & NOME \\
\hline A & TRATA \\
\hline B & EPOCA \\
\hline
\end{tabular}

QUADRO DA ANALISE DE VARIANCIA

\begin{tabular}{|c|c|c|c|c|c|}
\hline CAUSAS DA VARIACAO & G.L. & S.Q. & Q.M. & VALOR F & PROB. $>\mathrm{F}$ \\
\hline TRATA & 1 & 0.2980074 & 0.2980074 & 1.4248 & 0.24529 \\
\hline EPOCA & 4 & 10.6867285 & 2.6716821 & 12.7736 & 0.00009 \\
\hline $\mathrm{TRA} \star \mathrm{EPO}$ & 4 & 0.4508757 & 0.1127189 & 0.5389 & 0.71144 \\
\hline RESIDUO & 20 & 4.1831257 & 0.2091563 & & \\
\hline TOTAL & 29 & 15.6187373 & & & \\
\hline
\end{tabular}

MEDIA GERAL $=\quad 4.484334$

COEFICIENTE DE VARIACAO $=10.199 \%$

TESTE DE TUKEY PARA MEDIAS DE TRATA

\begin{tabular}{|c|c|c|c|c|c|c|c|}
\hline NUM. ORDEM & NUM. TRAT. & NOME & NUM. REPET. & MEDIAS & MEDIAS ORIGINAIS & $5 \%$ & $1 \%$ \\
\hline 1 & 1 & TRATA 1 & 15 & 4.584000 & 4.584000 & a & A \\
\hline 2 & 2 & TRATA 2 & 15 & 4.384667 & 4.384667 & a & A \\
\hline
\end{tabular}

MEDIAS SEGUIDAS POR LETRAS DISTINTAS DIFEREM ENTRE SI AO NIVEL DE SIGNIFICANCIA INDICADO D.M.S. $5 \%=0.34835-$ D.M.S. $1 \%=0.47470$

MEDIAS DO FATOR TRATA DENTRO DE EPOCA 1 DO FATOR EPOCA

\begin{tabular}{ccccc}
--1 & \\
NUM. TRAT. & NOME & NUM. REPET. & MEDIAS & MEDIAS ORIGINAIS \\
- & TRATA 1 & 3 & 4.233333 & 4.233333 \\
2 & TRATA 2 & 3 & 3.876667 & 3.876667 \\
\hline
\end{tabular}

MEDIAS DO FATOR TRATA

DENTRO DE EPOCA 2 DO FATOR EPOCA

\begin{tabular}{|c|c|c|c|c|}
\hline NUM. TRAT. & NOME & NUM. REPET. & MEDIAS & MEDIAS ORIGINAIS \\
\hline 1 & TRATA 1 & 3 & 4.240000 & 4.240000 \\
\hline 2 & TRATA 2 & 3 & 3.896667 & 3.896667 \\
\hline
\end{tabular}

MEDIAS DO FATOR TRATA

DENTRO DE EPOCA 3 DO FATOR EPOCA

\begin{tabular}{|c|c|c|c|c|}
\hline NUM. TRAT. & NOME & NUM. REPET. & MEDIAS & MEDIAS ORIGINAIS \\
\hline 1 & TRATA 1 & 3 & 3.793333 & 3.793333 \\
\hline 2 & TRATA 2 & 3 & 4.076667 & 4.076667 \\
\hline
\end{tabular}

MEDIAS DO FATOR TRATA

DENTRO DE EPOCA 4 DO FATOR EPOCA

\begin{tabular}{|c|c|c|c|c|}
\hline NUM. TRAT & NOME & NUM. REPET. & MEDIAS & MEDIAS ORIGINAIS \\
\hline 1 & TRATA 1 & 3 & 5.080000 & 5.080000 \\
\hline 2 & TRATA 2 & 3 & 4.736667 & 4.736667 \\
\hline
\end{tabular}


MEDIAS DO FATOR TRATA

DENTRO DE FPOCA 5 DO FATOR EPOCA

\begin{tabular}{|c|c|c|c|c|}
\hline NUM. TRAT. & NOME & NUM. REPET. & MEDIAS & MEDIAS ORIGINAIS \\
\hline 1 & TRATA 1 & 3 & 5.573334 & 5.573334 \\
\hline 2 & TRATA 2 & 3 & 5.336667 & 5.336667 \\
\hline
\end{tabular}

TESTE DE TUKEY PARA MEDIAS DE EPOCA

\begin{tabular}{|c|c|c|c|c|c|c|c|}
\hline NUM. ORDEM & NUM. TRAT. & NOME & NUM. REPET. & MEDIAS & MEDIAS ORIGINAIS & $5 \%$ & $1 \%$ \\
\hline 1 & 5 & EPOCA 5 & 6 & 5.455000 & 5.455000 & a & A \\
\hline 2 & 4 & EPOCA 4 & 6 & 4.908333 & 4.908333 & a & $A B$ \\
\hline 3 & 2 & EPOCA 2 & 6 & 4.068333 & 4.068333 & b & B \\
\hline 4 & 1 & EPOCA 1 & 6 & 4.055000 & 4.055000 & b & B \\
\hline 5 & 3 & EPOCA 3 & 6 & 3.935000 & 3.935000 & b & B \\
\hline
\end{tabular}

MEDIAS SEGUIDAS POR LETRAS DISTINTAS DIFEREM ENTRE SI AO NIVEL DE SIGNIFICANCIA INDICADO D.M.S. $5 \%=0.78977$ - D.M.S. $1 \%=0.98768$

MEDIAS DO FATOR EPOCA

DENTRO DE TRATA 1 DO FATOR TRATA

\begin{tabular}{|c|c|c|c|c|}
\hline NUM. TRAT. & NOME & NUM. REPET. & MEDIAS & MEDIAS ORIGINAIS \\
\hline 1 & EPOCA 1 & 3 & 4.233333 & 4.233333 \\
\hline 2 & EPOCA 2 & 3 & 4.240000 & 4.240000 \\
\hline 3 & EPOCA 3 & 3 & 3.793333 & 3.793333 \\
\hline 4 & EPOCA 4 & 3 & 5.080000 & 5.080000 \\
\hline 5 & EPOCA 5 & 3 & 5.573334 & 5.573334 \\
\hline
\end{tabular}

MEDIAS DO FATOR EPOCA

DENTRO DE TRATA 2 DO FATOR TRATA

\begin{tabular}{|c|c|c|c|c|}
\hline NUM. TRAT. & NOME & NUM. REPET. & MEDIAS & MEDIAS ORIGINAIS \\
\hline 1 & EPOCA 1 & 3 & 3.876667 & 3.876667 \\
\hline 2 & EPOCA 2 & 3 & 3.896667 & 3.896667 \\
\hline 3 & EPOCA 3 & 3 & 4.076667 & 4.076667 \\
\hline 4 & EPOCA 4 & 3 & 4.736667 & 4.736667 \\
\hline \multirow[t]{2}{*}{5} & EPOCA 5 & 3 & 5.336667 & 5.336667 \\
\hline & & & 5.336667 & 5.336667 \\
\hline
\end{tabular}




\section{Errata}

André Eduardo de Souza Belluco. Alterações fisiológicas e de composição em Saccharomyces cerevisiae sob condições não proliferantes.

\begin{tabular}{|c|c|c|c|c|}
\hline p. & ítem & linha & onde se lê & leia-se \\
\hline 5 & 2.1 & décima e & $\ldots$ os teores da & $\ldots$ os teores dos \\
\hline & & décima & composição centesimal & componentes da \\
\hline & & primeira & da biomassa ... & biomassa ... \\
\hline 5 & 2.1 & $\begin{array}{l}\text { décima } \\
\text { segunda }\end{array}$ & ... apresenta ... & ... apresentam ... \\
\hline 32 & 3.7 .4 & $\begin{array}{l}\text { décima } \\
\text { oitava }\end{array}$ & A expressão do teor ... & O teor ... \\
\hline 48 & 4.2 .3 & terceira & ... alcançou & ... alcançou \\
\hline & & & $\begin{array}{l}14,97 \mathrm{mg} / 100 \mathrm{mg} \text {, } \\
\text { enquanto ... }\end{array}$ & $\begin{array}{l}14,97 \mathrm{mg} \text { de glicose } / 100 \mathrm{mg} \\
\text { de matéria seca, } \\
\text { enquanto } . .\end{array}$ \\
\hline
\end{tabular}

